\title{
Chitosan-Coating Effect on the Characteristics of Liposomes: A Focus on Bioactive Compounds and Essential Oils: A Review
}

\author{
Carine Sebaaly $^{1, *}$, Adriana Trifan $^{2, *} * \mathbb{D}$, Elwira Sieniawska ${ }^{3}\left(\mathbb{D}\right.$ and Hélène Greige-Gerges ${ }^{1}$ \\ 1 Bioactive Molecules Research Laboratory, Department of Chemistry and Biochemistry, Faculty of Sciences, \\ Section II, Lebanese University, Jdaidet el-Matn B.P. 90656, Lebanon; hgreige@ul.edu.lb \\ 2 Department of Pharmacognosy, Faculty of Pharmacy, Grigore T. Popa University of Medicine and Pharmacy \\ Iasi, 700115 Iasi, Romania \\ 3 Department of Pharmacognosy, Medical University of Lublin, 20-093 Lublin, Poland; \\ esieniawska@pharmacognosy.org \\ * Correspondence: c.sebaaly@ul.edu.lb (C.S.); adriana.trifan@umfiasi.ro (A.T.); Tel.: +40-232301815 (A.T.)
}

check for

updates

Citation: Sebaaly, C.; Trifan, A.; Sieniawska, E.; Greige-Gerges, H Chitosan-Coating Effect on the Characteristics of Liposomes: A Focus on Bioactive Compounds and Essential Oils: A Review. Processes 2021, 9, 445. https://doi.org/ $10.3390 /$ pr9030445

Academic Editor: Dimitrios I. Gerogiorgis

Received: 9 February 2021

Accepted: 24 February 2021

Published: 1 March 2021

Publisher's Note: MDPI stays neutral with regard to jurisdictional claims in published maps and institutional affiliations.

Copyright: (c) 2021 by the authors. Licensee MDPI, Basel, Switzerland. This article is an open access article distributed under the terms and conditions of the Creative Commons Attribution (CC BY) license (https:// creativecommons.org/licenses/by/ $4.0 /)$.

\begin{abstract}
In recent years, liposomes have gained increasing attention for their potential applications as drug delivery systems in the pharmaceutic, cosmetic and food industries. However, they have a tendency to aggregate and are sensitive to degradation caused by several factors, which may limit their effectiveness. A promising approach to improve liposomal stability is to modify liposomal surfaces by forming polymeric layers. Among natural polymers, chitosan has received great interest due to its biocompatibility and biodegradability. This review discussed the characteristics of this combined system, called chitosomes, in comparison to those of conventional liposomes. The coating of liposomes with chitosan or its derivatives improved liposome stability, provided sustained drug release and increased drug penetration across mucus layers. The mechanisms behind these results are highlighted in this paper. Alternative assembly of polyelectrolytes using alginate, sodium hyaluronate, or pectin with chitosan could further improve the liposomal characteristics. Chitosomal encapsulation could also ensure targeted delivery and boost the antimicrobial efficacy of essential oils (EOs). Moreover, chitosomes could be an efficient tool to overcome the major drawbacks related to the chemical properties of EOs (low water solubility, sensitivity to oxygen, light, heat, and humidity) and their poor bioavailability. Overall, chitosomes could be considered as a promising strategy to enlarge the use of liposomes.
\end{abstract}

Keywords: chitosan; coating; essential oils; liposomes; mechanism; polyelectrolyte

\section{Introduction}

Liposomes are spherical vesicles comprising a central aqueous compartment surrounded by a membrane constituted mainly of phospholipids and cholesterol in some cases. They are biocompatible, biodegradable, non-immunogenic and non-toxic [1]. In their original form, liposomes have a tendency to aggregate and fuse, which leads to drug leakage during storage [2]. This poor stability in an aqueous medium has major consequences on their shelf life [3]. The pH, bile salts and enzymes in the gastrointestinal (GI) tract can destabilize the liposome membrane [4]. In fact, the acidic $\mathrm{pH}$ of the stomach and the lipases hydrolyze the ester bonds of phospholipids that form liposomes. The bile salts act as surfactants leading to liposome membrane solubilization [5]. Liposomes are also prone to rapid elimination from the circulation system after intravenous injection [6]. In order to overcome these problems, covering the liposome's surface with polymers has been developed. The coating of liposomes with polyethylene glycol (PEG) reduced their uptake by the mononuclear phagocyte system, resulting in a prolonged blood circulation time of liposomes [7]. The surface modification of liposomes with PEG can be achieved by physically adsorbing the polymer onto the surface of vesicles, by anchoring the polymer in the liposomal membrane via a cross-linked lipid, such as distearoylphosphatidylethanolamine 
(DSPE) during liposome preparation, or by covalently attaching reactive groups onto the surface of preformed liposomes [7]. Stealth liposomes provided delayed and targeted drug delivery, enhancing the effectiveness of the transported drug and reducing its side effects [8]. PEGylated liposomes have reached clinical usage, such as DOXIL ${ }^{\circledR}$, originally developed by Sequus Pharmaceuticals in 1995, for the intravenous administration of the anticancer drug doxorubicin for the management of advanced ovarian cancer, multiple myeloma and Kaposi's sarcoma [9].

The use of natural polymers received increasing attention, particularly chitosan, which is isolated from crustacean exoskeletons, squid pen and fungi. Chitosan, a linear cationic polysaccharide composed of $\beta$-(1,4)-linked-2-amino-2-deoxy-D-glucopyranose (glucosamine) and 2-acetamido-2-deoxy-D-glucopyranose ( $\mathrm{N}$-acetylglucosamine), is obtained by alkaline or enzymatic deacetylation of chitin [10]. The chitin and chitosan structures are presented in Figure 1.

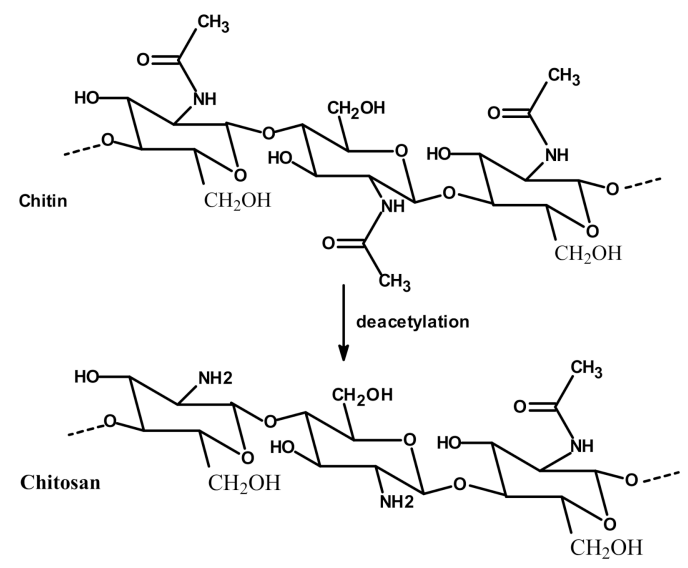

Figure 1. Chitosan product from chitin deacetylation.

The degree of deacetylation (DD) is defined as the glucosamine/N-acetylglucosamine ratio; in other words, DD is the percentage of glucosamine units present in the copolymer chain. Chitosan is soluble in an acidic aqueous medium. Under acidic $\mathrm{pH}$, the amino groups in the chitosan chain become protonated, and the polymer dissolves in aqueous media. Its solubility is related to the DD, molecular weight (MW) and distribution of the acetyl and amino groups along the chain [11]. For example, the increase in chitosan MW from 5 to $50 \mathrm{kDa}$ led to a significant decrease in chitosan aqueous solubility from 123.2 to $0.4 \mathrm{mg} / \mathrm{mL}$ [12]. Solubility at neutral $\mathrm{pH}$ has been claimed for chitosan with a DD of around 50\% [13]. For very high DD (>75\%), protonated charge condensation occurs in the chitosan solution due to large charge density, which leads to electrostatic repulsion and high solubility [14]. Indeed, the degree of deacetylation showed a great effect on $\mathrm{pKa}$ values, which were increased from 6.17 to 6.51 , with the degree of deacetylation decreasing from 94.6 to $73.3 \%$ [11]. The distribution of acetyl groups along the chain may influence the solubility of the polymer and also the inter-chain interactions due to the hydrogen bonds and the hydrophobic character of the acetyl group [13].

Chitosan has been considered as a biomaterial for drug delivery systems, as it possesses low toxicity, high biocompatibility [15], and in vivo biodegradability via lysozymes and human chitinases [16]. In addition, it exhibits numerous biological activities, including mucoadhesive [17], antioxidant [18], antimicrobial activity against Gram-positive and Gram-negative bacteria [19], wound healing capacity [20], and the in vitro and in vivo ability to complex genetic material [21]. Thus, a great interest has been shown for its applications in areas such as hematology, immunology, wound healing, drug delivery, food packaging and cosmetics.

On the other hand, the chitosan structure can be modified through its amino and hydroxyl groups. The preparation of chitosan derivatives has been carried out to improve 
chitosan properties, including solubility and bring new functional properties and promising applications. The aim of the chemical modifications of chitosan and the resulted structures used in the liposome coating are presented in Table 1.

Table 1. Chemical structures of chitosan and its derivatives and role of chitosan modification in liposome coating.

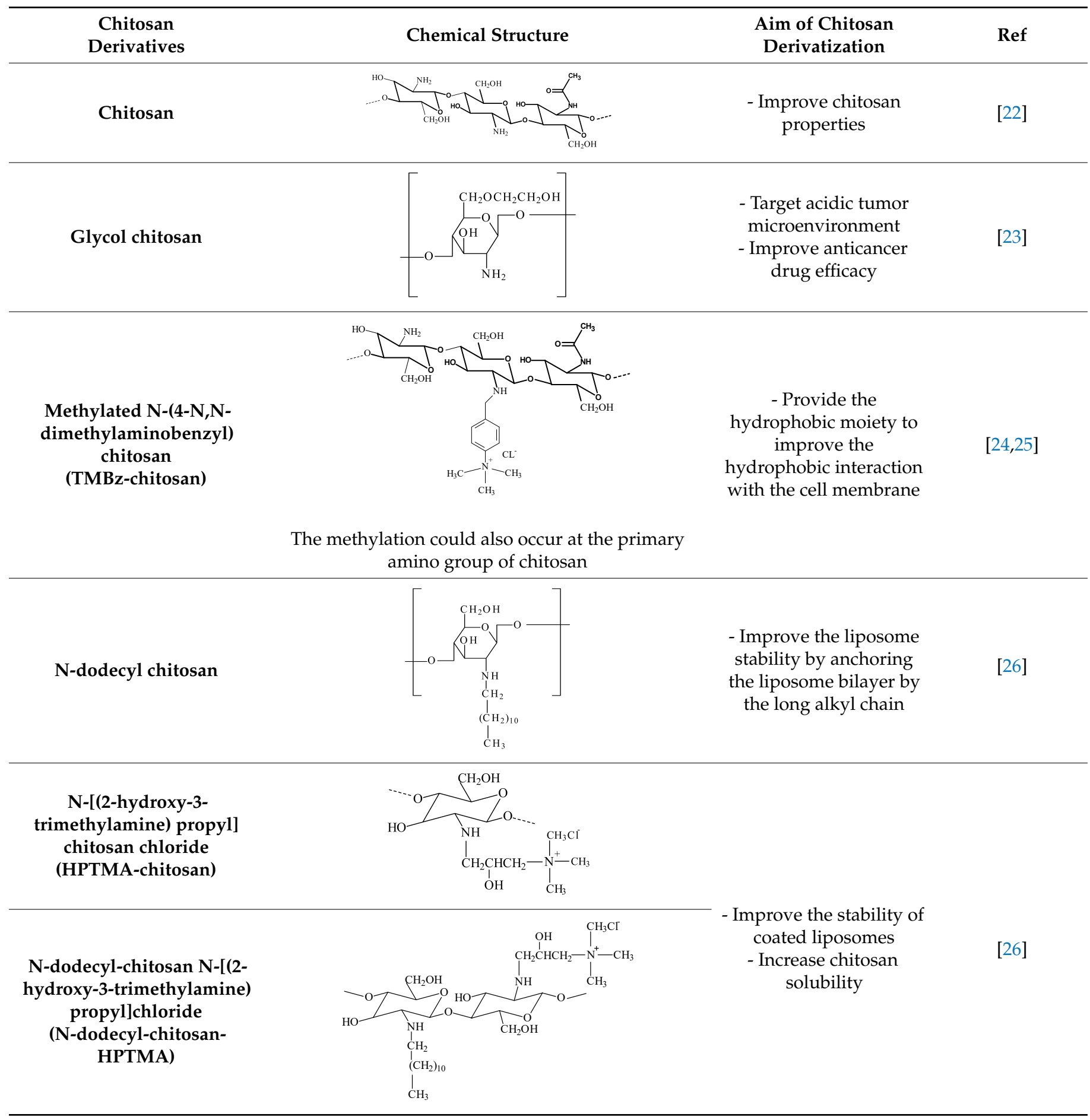


Table 1. Cont.

\begin{tabular}{|c|c|c|c|}
\hline $\begin{array}{c}\text { Chitosan } \\
\text { Derivatives }\end{array}$ & Chemical Structure & $\begin{array}{l}\text { Aim of Chitosan } \\
\text { Derivatization }\end{array}$ & Ref \\
\hline N-trimethyl chitosan & $\sum_{\mathrm{n}}^{\mathrm{OH}}$ & $\begin{array}{l}\text { - Improve chitosan } \\
\text { solubility over a wide } \\
\text { pH range } \\
\text { - Improve liposomal } \\
\text { stability }\end{array}$ & {$[27,28]$} \\
\hline $\begin{array}{c}\text { PEGylated } \\
\text { octadecyl-quaternized } \\
\text { lysine modified chitosan }\end{array}$ & 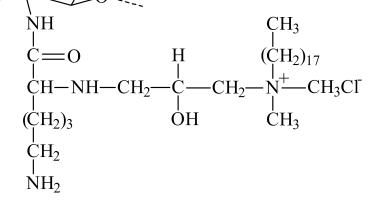 & $\begin{array}{l}\text { - Provide amphiphilic } \\
\text { character and steric } \\
\text { stabilizations }\end{array}$ & [22] \\
\hline $\begin{array}{l}\text { Pelargonic chitosan }(n=7) \\
\text { Lauric chitosan }(n=10)\end{array}$ & $\begin{array}{l}\left.\mathrm{C}_{\mathrm{C}}^{\mathrm{C}} \mathrm{H}_{2}\right) \mathrm{n} \\
\mathrm{CH}_{3}\end{array}$ & $\begin{array}{c}\text { - Coat positively charged } \\
\text { liposomes with } \\
\text { mucoadhesive } \\
\text { properties. } \\
\text { - The side groups } \\
\text { introduced into the } \\
\text { polysaccharide chains } \\
\text { provide additional steric } \\
\text { stabilization for } \\
\text { liposomes in solutions }\end{array}$ & [29] \\
\hline $\begin{array}{l}\text { Thioglycolic acid chitosan } \\
\text { (TGA-chitosan) }\end{array}$ & $y^{\circ-}$ & $\begin{array}{l}\text { - Improve the } \\
\text { mucoadhesive property } \\
\text { and enhance oral } \\
\text { bioavailability of } \\
\text { peptides }\end{array}$ & [30] \\
\hline $\begin{array}{l}\text { Thioglycolic acid } \\
\text { 6-mercaptonicotinamide- } \\
\text { conjugate chitosan } \\
\text { (TGA-MNA-chitosan) }\end{array}$ & $\int_{\mathrm{OH}}^{\mathrm{CH}_{2} \mathrm{OH}} \sqrt{-}$ & $\begin{array}{l}\text { - Thioglycolic acid } \\
\text { chitosan was S-protected } \\
\text { via conjugation with } \\
6,6^{\prime} \text {-dithionicotinamide } \\
\text { resulting in a derivative } \\
\text { being less prone to } \\
\text { oxidation and exhibiting } \\
\text { higher mucoadhesive } \\
\text { properties }\end{array}$ & [30] \\
\hline
\end{tabular}

Chitosan has been known to coat the surface of negatively charged liposomes due to electrostatic interactions between negatively charged phospholipids and positive charges of primary amino groups of chitosan [31]. Other mechanisms, such as hydrogen bonding between the polysaccharide and the phospholipid head groups, can also be implicated in the chitosan coating process [32]. Figure 2 illustrates the combined system named chitosome.

This review is focused on the effect of chitosan coating on liposomal characteristics. The method used to prepare drug-loaded chitosomes is presented. Conventional liposomes, chitosan- and modified chitosan-coated liposomes are compared for their characteristics, including particle size, zeta potential, polydispersity index (pdI), morphology, encapsulation efficiency (EE), stability, drug release, pharmacokinetics and pharmacodynamics. Literature data concerning the comparison between both systems are resumed into different tables (Tables 2-12). Mechanisms controlling vesicle stability, drug release and mucoadhesivity are also highlighted in this paper. In addition, a section deals with a multilayer 
coating of polyelectrolytes using alginate, sodium hyaluronate or pectin with chitosan on the liposome surface. The last section is dedicated to chitosomal encapsulation of essential oils (EOs) and its perspectives for the clinical development of novel therapeutic agents with increased stability and prolonged release.

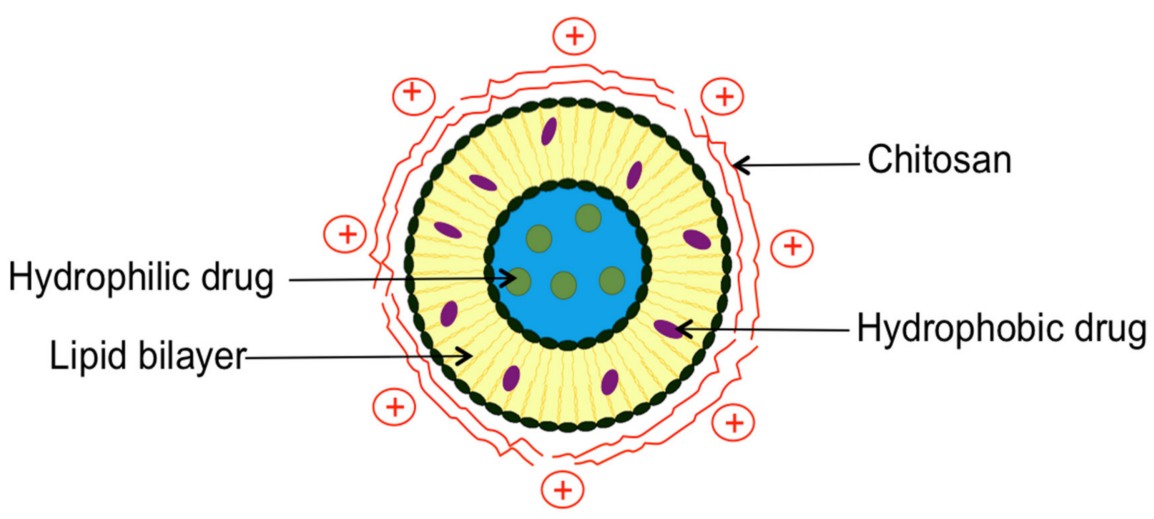

Figure 2. Schematic representation of drug-loaded chitosomes.

\section{Chitosomes Preparation Method}

Chitosan-coated liposomes are being prepared by a dropwise addition of a defined volume of chitosan solution to the same volume of liposome suspension and kept under stirring for 1 or $2 \mathrm{~h}$. Chitosan should be dissolved either in acetic acid solution adjusted to $\mathrm{pH} 4-5$, hydrogen chloride $(\mathrm{HCl})$ solution or phosphate-buffered saline (PBS) buffer ( $\mathrm{pH} 7.4)$, and incubated overnight at room temperature [33-35].

\section{Comparison between Conventional Liposomes and Chitosomes}

A comparison between chitosan- or chitosan derivative-coated liposomes and conventional liposomes encapsulating various drugs is detailed below. Tables 2-5 summarize the characteristics of conventional liposomes and chitosomes loading natural bioactive molecules (plant extracts, EOs, vitamins), antimicrobials, drugs of different classes (anticancer, anti-inflammatory, anesthetic, anti-histaminic, diuretic and immunosuppressive), macromolecules (proteins, deoxyribonucleic acid (DNA)) and active peptides, respectively. Chitosan coating effect is discussed in the following paragraphs regarding the particles size, zeta potential, pdI, morphology, EE, stability, drug release, pharmacokinetics and pharmacodynamics behavior of drugs.

\subsection{Particles Size}

In contrast to a single previous study focusing on the encapsulation of EOs in lipid vesicles and where liposomes of micrometric size were obtained [36], the coating of liposomes with chitosan produced an increase in liposome size (Tables 2-5). The increase was probably due to the bridging between chitosan and liposomes [37,38]. Liposome size depends on chitosan concentration. The particle size of polymer-coated liposomes increased with increasing chitosan concentration from 0.05 to $1.2 \%(w / v)$, forming thicker coating layers with a higher concentration of chitosan $[4,5,12,28,35,38-44,46,47]$. However, extensive aggregation occurred at low chitosan concentration ranging from 0.025 to $0.2 \%(w / v)$ regarding phospholipid concentration $[48,49]$. When liposome surfaces are not saturated with chitosan, liposomes associate with each other due to charge neutralization as surface charge consists of both partially negative and positive charges. Moreover, when there is excess chitosan, bridging flocculation caused by the interaction between the extended chitosan segments on the liposome surfaces will lead to particle-polymer-particle bridges. Hence, the stability of chitosomes relies on a sufficient chitosan concentration [49].

Additionally, the effect of different chitosan MW (65, 140, 680, $1000 \mathrm{kDa})$ on the size of insulin-loaded liposomes was investigated, and no significant differences were 
observed [38]. However, chitosomes prepared with trimethyl chitosan of high MW (HMW of $450 \mathrm{kDa}$ ) exhibited greater mean size than those prepared with low MW (LMW of $100 \mathrm{kDa}$ ), which can be explained by the presence of long-chain molecules of trimethyl chitosan leading to high viscosity and more adsorbed polymer [28].

Moreover, the composition of lipid vesicles, especially the phospholipid type used, may also affect the chitosome size. Conventional liposomes composed of Epikuron 170 have a smaller size than those composed of Epikuron 200. Liposomes obtained from Epikuron 170 composed of $70 \%$ phosphatidylcholine, 10\% phosphatidylethanolamine, $3 \%$ phosphatidylinositol, $3 \%$ phosphatidic acid and $4 \%$ lysophosphatidylcholine absorbed more chitosan than those prepared with Epikuron 200 composed of 92\% phosphatidylcholine and 3\% lysophosphatidylcholine [40]. In addition, the size of uncharged liposome types tested (egg phosphatidylcholine (EPC) and distearoylphatidylcholine (DSPC)) is minimally affected by chitosan compared to negatively charged vesicles (EPC/phosphatidylglycerol (PG) and DSPC/PG) that become substantially larger as the chitosan/lipid ratio increases [32].

The liposome preparation method could affect chitosome size. Chitosomes loading curcumin prepared by ethanol injection method (EIM) were slightly larger than those prepared by thin-film hydration method (TFH) for the entire chitosan concentration range (0.1 to $0.5 \%)$ [43].

\subsection{Zeta Potential}

Several studies have investigated the effect of chitosan or chitosan derivatives on the Zeta potential values of the liposomes. The presence of polymer coating on the liposome surface is confirmed by the inversion of the Zeta potential from negative to positive values between uncoated and coated systems (Tables $2-5$ ). Since chitosan carried a high positive charge, the adsorption of chitosan increased the density of positive charge and made the Zeta potential positive $[4,36,42,50]$.

Moreover, Zeta potential values increased when the chitosan concentration increased from 0.1 to $0.3 \%(w / v)$, then it reached a relatively constant value, indicating the saturated adsorption of chitosan to liposomes [12,28,35,40,42,47-49,51-53]. It is important to mention that the modification of the surface of the liposome by another polymer, such as PEG, also changes the Zeta potential by varying polymer to lipid ratio from 1 to $10 \%(w / w)$ depending on the experimental protocol used based on a supercritical $\mathrm{CO}_{2}$ assisted process. In the first method, the PEG dissolved in water was premixed in an ethanolic lipid solution (ethanol/water ratio $80 / 20(v / v)$ ), and the final solution was fed to supercritical assisted apparatus, while in the second method, PEG was dissolved in a separate aqueous solution and the two feeding solutions (aqueous and lipidic) were fed separately to the process. The authors explained the variations of Zeta potential between the two experimental protocols by the fact that PEG exhibits a better coverage of the liposome surface using the first method, which allows the addition of different amounts of PEG, resulting in a variety of surface charge [8].

It should be noted that the DD plays an important role in the effect of different chitosan MW on the zeta potential of the liposomes. The DD (85\%) of HMW of chitosan (150 kDa) was slightly higher $(80 \%)$ than that of LMW of chitosan $(22 \mathrm{kDa})$, the number of protonated amine groups on HMW chitosan was higher than that on LMW chitosan, resulting in high positive zeta potential value [54].

\subsection{Homogeneity}

Although chitosan coating broadened the mean vesicle diameter [49], the pdI values remained below or close to 0.5 , indicating an acceptable degree of polydispersity (Tables 2-5). The pdI values of chitosomes loading curcumin prepared by EIM were smaller than those prepared by TFH for the entire chitosan concentration range (0 to $0.5 \%)$ [43]. 


\subsection{Morphology}

Transmission electron microscopy was used to visualize conventional liposomes and chitosomes. Both systems were spherical. The existence of chitosan surrounding the liposomes has been well visualized on chitosomes surface $[15,33,37,40,43,44,47,51,52,55,56]$. No significant morphological differences, except size, between liposomes with or without chitosan coating were observed $[35,44,55]$. This was explained by strong adsorption between the polymer and the liposomal bilayer [35]. However, some aggregations were observed after coating $[44,46,55,57]$.

\subsection{Encapsulation Efficiency}

Drug EE is calculated as the ratio of drug content within the liposomes to the total drug content of the suspension. The comparison of EE values between drug-loaded liposomes and chitosomes is discussed in this section and presented in Tables 2-5.

Different results were obtained in the literature concerning the chitosan coating effect on drug EE in liposomes. This discrepancy may be due to drug physicochemical properties (solubility, partition coefficient, ionization), its location in vesicles and orientation inside the liposomal membrane, as well as the medium $\mathrm{pH}$. For example, many studies demonstrated that chitosan coating decreased the EE of drugs, mostly having positive charges at $\mathrm{pH}$ range between 4 and 7.4 compared to uncoated liposomes as presented in Tables $2-5[5,34,35,37,38,40,42,48,56-59]$. It was explained as a consequence of positively charged chitosan and positively charged drug competing for the negatively charged phospholipids $[34,37,40,48]$.

However, other studies showed an increase in the EE of other drugs in the presence of chitosan at a pH range between 4 and 7.4 [4,32,43,44,49,55,60-63]. This may be due to the surface properties following the addition of chitosan during preparation which created the ionic interaction between positive chitosan and negative drug in solution producing high drug loading $[4,55,60,61]$. In addition, the coating enlarged EE, probably due to polyphenols interaction with chitosan [62]. Conceivably, the chitosan layer prevented carotenoid or curcumin leakage from the bilayer core [44,64].

The drug EE in chitosomes may also be affected by chitosan concentration, chitosan MW and liposomal preparation method. A further increase in chitosan concentration resulted in a non-significant change in drug $\mathrm{EE}[37,41]$. This may be explained by the fact that the adsorptive layer has already been formed, and thus chitosan surrounds liposomes from the outside $[37,40,41]$. In addition, insulin EE in chitosomes was slightly increased with an increase in chitosan MW from 65 to $1000 \mathrm{kDa}$ [38]. Curcumin EE in liposomes prepared by EIM ( $54.7 \%$ ) was higher than that obtained in the liposomes prepared by TFH (42.6\%) under the same conditions [43].

\subsection{Chitosomes Stability}

This section is dedicated to literature data related to the stability of conventional liposomes and chitosomes (in suspensions or dried forms) over time under various conditions, such as storage temperature, chitosan concentration and medium composition. The mechanism controlling vesicle stability in the presence of chitosan is explained below. 


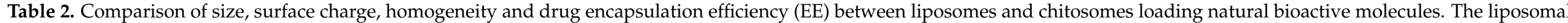
composition is indicated in the table in molar ratio except when * exists, indicating a weight ratio $(w / w)$.

\begin{tabular}{|c|c|c|c|c|c|c|c|c|c|c|c|}
\hline \multirow{2}{*}{$\begin{array}{l}\text { Natural } \\
\text { Molecules }\end{array}$} & \multirow{2}{*}{$\begin{array}{l}\text { Liposomes } \\
\text { a. Composition } \\
\text { b. Preparation } \\
\text { Method }\end{array}$} & \multirow{2}{*}{$\begin{array}{c}\text { Chitosan or Chitosan Derivative } \\
\text { a. Concentration }(\% \text { w/v) } \\
\text { b. MW (kDa) } \\
\text { c. DD (\%) } \\
\text { d. Chitosan Type }\end{array}$} & \multicolumn{2}{|l|}{ Size (nm) } & \multicolumn{2}{|c|}{ Zeta Potential (mV) } & \multicolumn{2}{|c|}{ pdI } & \multicolumn{2}{|c|}{ EE } & \multirow[t]{2}{*}{ Ref } \\
\hline & & & CH-LP & UN-LP & CH-LP & UN-LP & CH-LP & UN-LP & CH-LP & UN-LP & \\
\hline Artemisia afra & $\begin{array}{l}\text { a. DSPC:DSPE 94:6 } \\
\text { b. REV+sonication }\end{array}$ & $\begin{array}{l}\text { a. } 0.15 \\
\text { b. LMW } \\
\text { c. NR } \\
\text { d. Chitosan }\end{array}$ & $1079 \pm 62$ & $8269 \pm 79$ & 22.8 & 9.0 & 0.798 & 0.429 & NR & 18.7 & [36] \\
\hline $\begin{array}{c}\text { Berberine } \\
\text { hydrochloride }\end{array}$ & $\begin{array}{c}\text { a. EPC:CHO:DHP } \\
\text { 1:0.242:0.036* } \\
\text { b. TFH+sonication }\end{array}$ & $\begin{array}{l}\text { a. } 0.1 ; 0.3 \\
\text { b. NR } \\
\text { c. }>90 \\
\text { d. Chitosan }\end{array}$ & $194 \pm 3-264 \pm 8$ & $142 \pm 5$ & $24.1-29.3$ & -26.8 & $0.34-0.53$ & 0.27 & 78.4-81.6 & 83.2 & [5] \\
\hline $\begin{array}{l}\text { Black } \\
\text { mulberry } \\
\text { extract }\end{array}$ & $\begin{array}{l}\text { a. Lecithin }(2 \% w / v) \\
\text { b. Homogenization }\end{array}$ & $\begin{array}{l}\text { a. } 0.4 \\
\text { b. NR } \\
\text { c. } 80 \\
\text { d. Chitosan }\end{array}$ & $473 \pm 12.7$ & $173 \pm 1.2$ & 41.8 & -32.4 & NR & NR & NR & NR & [65] \\
\hline $\begin{array}{l}\text { Carotenoids: } \\
\text { lutein; } \\
\beta \text {-carotene; } \\
\text { lycopene; } \\
\text { canthaxanthin }\end{array}$ & $\begin{array}{l}\text { a. EPC:Tween-80 NR } \\
\text { b. TFH+ sonication }\end{array}$ & $\begin{array}{l}\text { a. } 0.05 ; 0.1 ; 0.15 \\
\text { b. } 200 \\
\text { c. } 85 \\
\text { d. Chitosan }\end{array}$ & $\begin{array}{c}78-83 \pm 0.1 \\
76-78 \pm 0.1 \\
72-75 \pm 0.1 \\
125-130 \pm 1.4\end{array}$ & $\begin{aligned} 77 & \pm 0.1 \\
75 & \pm 0.1 \\
70 & \pm 0.1 \\
120 & \pm 1.4\end{aligned}$ & $\begin{array}{l}9.3-20 \\
9.3-20 \\
9.3-20 \\
9.3-20\end{array}$ & $\begin{array}{l}-5.3 \\
-5.3 \\
-5.3 \\
-5.3\end{array}$ & $\begin{array}{c}0.17-0.22 \\
0.2-0.25 \\
0.23-0.25 \\
0.3-0.32\end{array}$ & $\begin{array}{l}0.15 \\
0.18 \\
0.22 \\
0.32\end{array}$ & $\begin{array}{l}87-92 \\
86-88 \\
76-85 \\
59-65\end{array}$ & $\begin{array}{l}87 \\
86 \\
75 \\
58\end{array}$ & [44] \\
\hline $\begin{array}{l}\text { Coenzyme } \\
\text { Q10 }\end{array}$ & $\begin{array}{l}\text { a. SPC:CHO 83:17* } \\
\text { b. EIM+ sonication }\end{array}$ & $\begin{array}{c}\text { a. } 0.1 ; 0.2 ; 0.5 ; 1 \\
\text { b. } 100 ; 450 \\
\text { c. }>85 \\
\text { d. N-trimethyl chitosan }\end{array}$ & $\begin{array}{l}193-331 \\
245-354\end{array}$ & 136 & $\begin{array}{l}4.1-24.1 \\
8.1-25.1\end{array}$ & -8.7 & NR & NR & 98 & 98 & [28] \\
\hline \multirow{2}{*}{ Curcumin } & $\begin{array}{l}\text { a. EPC:CHO 2:1 } \\
\text { b. EIM }\end{array}$ & $\begin{array}{l}\text { a. } 0.1-0.5 \\
\text { b. } 30 \\
\text { c. } 88 \\
\text { d. Chitosan }\end{array}$ & $123 \pm 0.8-204 \pm 0.6$ & $101.4 \pm 5$ & $30.1-32.1$ & -14.1 & $0.185-0.216$ & 0.247 & 64.93 & 54.7 & \multirow{2}{*}{ [43] } \\
\hline & $\begin{array}{l}\text { a. EPC:CHO 2:1 } \\
\text { b. TFH+ sonication }\end{array}$ & $\begin{array}{l}\text { a. } 0.1-0.5 \\
\text { b. } 30 \\
\text { c. } 88 \\
\text { d. Chitosan }\end{array}$ & $104 \pm 1-192 \pm 0.8$ & $115.7 \pm 2.3$ & $30.4-43$ & -20.1 & $0.218-0.281$ & 0.388 & NR & 42.6 & \\
\hline
\end{tabular}


Table 2. Cont.

\begin{tabular}{|c|c|c|c|c|c|c|c|c|c|c|c|}
\hline \multirow{2}{*}{$\begin{array}{l}\text { Natural } \\
\text { Molecules }\end{array}$} & \multirow{2}{*}{$\begin{array}{l}\text { Liposomes } \\
\text { a. Composition } \\
\text { b. Preparation } \\
\text { Method }\end{array}$} & \multirow{2}{*}{$\begin{array}{c}\text { Chitosan or Chitosan Derivative } \\
\text { a. Concentration }(\% \text { w/v) } \\
\text { b. MW (kDa) } \\
\text { c. DD }(\%) \\
\text { d. Chitosan Type }\end{array}$} & \multicolumn{2}{|c|}{ Size (nm) } & \multicolumn{2}{|c|}{ Zeta Potential (mV) } & \multicolumn{2}{|c|}{ pdI } & \multicolumn{2}{|c|}{ EE } & \multirow[t]{2}{*}{ Ref } \\
\hline & & & CH-LP & UN-LP & CH-LP & UN-LP & CH-LP & UN-LP & CH-LP & UN-LP & \\
\hline & $\begin{array}{l}\text { a. PC:CHO 5:1* } \\
\text { b. EIM }\end{array}$ & $\begin{array}{l}\text { a. } 1 \\
\text { b. } 28 \\
\text { c. } 89 \\
\text { d. Chitosan }\end{array}$ & $332.7 \pm 53.8$ & $93.2 \pm 8.2$ & 67.1 & -24.3 & NR & NR & 52.08 & 41.42 & [66] \\
\hline & \multirow{3}{*}{$\begin{array}{c}\text { a. EPC:DHP:CHO NR } \\
\text { b. NR }\end{array}$} & $\begin{array}{c}\text { a. } 0.0025 \\
\text { b. NR } \\
\text { c. } 80 \\
\text { d. N-dodecyl chitosan }\end{array}$ & 140.3 & 51.7 & 31.6 & -39 & NR & NR & NR & NR & \multirow{3}{*}{ [26] } \\
\hline & & $\begin{array}{c}\text { a. } 0.0025 \\
\text { b. NR } \\
\text { c. } 80 \\
\text { d. HPTMA-chitosan }\end{array}$ & 76.3 & 51.7 & 32 & -39 & NR & NR & NR & NR & \\
\hline & & $\begin{array}{c}\text { a. } 0.0025 \\
\text { b. NR } \\
\text { c. } 80 \\
\text { d. N-dodecyl chitosan-HPTMA } \\
\end{array}$ & 73.1 & 51.7 & 32.3 & -39 & NR & NR & NR & NR & \\
\hline & $\begin{array}{l}\text { a. EPC: Phosphatidic } \\
\text { acid } 6.5: 3.5 \\
\text { b. REV }\end{array}$ & $\begin{array}{l}\text { a. } 0.1 \\
\text { b. NR } \\
\text { c. NR } \\
\text { d. Chitosan }\end{array}$ & 300 & 129 & 33 & -49 & 0.1 & 0.095 & NR & NR & [67] \\
\hline & $\begin{array}{l}\text { a. SPC:CHO 20:2 * } \\
\text { b. TFH+ extrusion }\end{array}$ & $\begin{array}{c}\text { a. } 0.5 \\
\text { b. } 200 \\
\text { c. }>85 \\
\text { d. N-trimethyl chitosan }\end{array}$ & 657.7 & 221.4 & 15.6 & -9.6 & 0.37 & 0.198 & 92.6 & 86.6 & [27] \\
\hline $\begin{array}{l}\text { Eucalyptus } \\
\text { globulus }\end{array}$ & $\begin{array}{l}\text { a. DSPC:DSPE } 94: 6 \\
\text { b. REV+sonication }\end{array}$ & $\begin{array}{l}\text { a. } 0.15 \\
\text { b. LMW } \\
\text { c. NR } \\
\text { d. Chitosan }\end{array}$ & $885 \pm 119$ & $9914 \pm 224$ & 13.0 & -14.9 & 0.678 & 0.585 & NR & 69.2 & [36] \\
\hline \multirow{2}{*}{$\begin{array}{l}\text { Grape seed } \\
\text { extract }\end{array}$} & \multirow{2}{*}{$\begin{array}{l}\text { a. Lipoid S75 1\%* } \\
\text { b. High-pressure } \\
\text { homogenizer }\end{array}$} & $\begin{array}{l}\text { a. } 0.1 \\
\text { b. NR } \\
\text { c. } 79 \\
\text { d. Chitosan }\end{array}$ & $173 \pm 0.1$ & $84 \pm 0.1$ & 63 & -49 & 0.4 & 0.3 & 86.6 & 85.4 & [68] \\
\hline & & $\begin{array}{l}\text { a. } 1 \\
\text { b. NR } \\
\text { c. } 79 \\
\text { d. Chitosan }\end{array}$ & $160.3 \pm 0.1$ & $86.5 \pm 0.1$ & 64.9 & -42.5 & NR & NR & 99.5 & 88.2 & [62] \\
\hline
\end{tabular}


Table 2. Cont.

\begin{tabular}{|c|c|c|c|c|c|c|c|c|c|c|c|}
\hline \multirow{2}{*}{$\begin{array}{l}\text { Natural } \\
\text { Molecules }\end{array}$} & \multirow{2}{*}{$\begin{array}{l}\text { Liposomes } \\
\text { a. Composition } \\
\text { b. Preparation } \\
\text { Method }\end{array}$} & \multirow{2}{*}{$\begin{array}{c}\text { Chitosan or Chitosan Derivative } \\
\text { a. Concentration }(\% \text { w/v) } \\
\text { b. MW (kDa) } \\
\text { c. DD }(\%) \\
\text { d. Chitosan Type }\end{array}$} & \multicolumn{2}{|c|}{ Size (nm) } & \multicolumn{2}{|c|}{ Zeta Potential (mV) } & \multicolumn{2}{|c|}{ pdI } & \multicolumn{2}{|c|}{ EE } & \multirow[t]{2}{*}{ Ref } \\
\hline & & & CH-LP & UN-LP & CH-LP & UN-LP & CH-LP & UN-LP & CH-LP & UN-LP & \\
\hline $\begin{array}{l}\text { Melaleuca } \\
\text { alternifolia }\end{array}$ & $\begin{array}{l}\text { a. DSPC:DSPE 94:6 } \\
\text { b. REV+sonication }\end{array}$ & $\begin{array}{l}\text { a. } 0.15 \\
\text { b. LMW } \\
\text { c. NR } \\
\text { d. Chitosan } \\
\end{array}$ & $5781 \pm 51$ & $9280 \pm 654$ & 30.0 & 1.4 & 0.845 & 0.491 & NR & 41.7 & [36] \\
\hline Resveratrol & $\begin{array}{l}\text { a. EPC } 2 \%(w / v) \\
\text { b. TFH+ sonication }\end{array}$ & $\begin{array}{l}\text { a. } 0.1 ; 0.3 ; 0.5 \\
\text { b. NR } \\
\text { c. NR } \\
\text { d. Chitosan }\end{array}$ & $279.8-558.3 \pm 0.2$ & $212.8 \pm 0.01$ & $26.3-39.2$ & -9.4 & NR & NR & 81.3 & 83.9 & [42] \\
\hline $\begin{array}{l}\text { Rosmarinic } \\
\text { acid esters }\end{array}$ & $\begin{array}{l}\text { a. Lecithin } 1 \%(w / v) \\
\text { b. Homogenization }\end{array}$ & $\begin{array}{l}\text { a. } 0.2 \\
\text { b. } 205 \\
\text { c. } 91.8 \\
\text { d. Chitosan }\end{array}$ & 205.1 & 87.8 & 66.3 & -37.8 & NR & NR & NR & NR & [69] \\
\hline Vitamin E & $\begin{array}{l}\text { a. PC:CHO 20:80; } 40: 60 ; \\
60: 40 ; 80: 20 \\
\text { b. Sonication }\end{array}$ & $\begin{array}{l}\text { a. } 0.1 \\
\text { b. } 4 \\
\text { c. }>90 \\
\text { d. Chitosan }\end{array}$ & $144-531 \pm 5$ & $\begin{array}{c}133- \\
357 \pm 5\end{array}$ & 53.5 & -29.5 & NR & NR & $55.4-99.8$ & NR & {$[70]$} \\
\hline
\end{tabular}

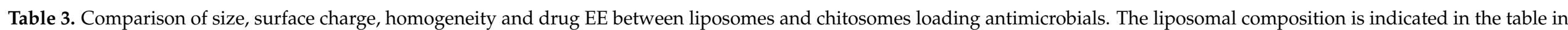
molar ratio except when * exists, indicating a weight ratio $(w / w)$.

\begin{tabular}{|c|c|c|c|c|c|c|c|c|c|c|c|}
\hline \multirow{2}{*}{ Antimicrobials } & \multirow{2}{*}{$\begin{array}{l}\text { Liposomes } \\
\text { a. Composition } \\
\text { b. Preparation } \\
\text { Method }\end{array}$} & \multirow{2}{*}{$\begin{array}{c}\text { Chitosan or Chitosan Derivative } \\
\text { a. Concentration }(\% \text { w/v) } \\
\text { b. MW (kDa) } \\
\text { c. DD (\%) } \\
\text { d. Chitosan Type }\end{array}$} & \multicolumn{2}{|c|}{ Size (nm) } & \multicolumn{2}{|c|}{ Zeta Potential (mV) } & \multicolumn{2}{|c|}{ pdI } & \multicolumn{2}{|c|}{ EE } & \multirow[t]{2}{*}{ Ref } \\
\hline & & & CH-LP & UN-LP & CH-LP & UN-LP & CH-LP & UN-LP & CH-LP & UN-LP & \\
\hline Clotrimazole & $\begin{array}{l}\text { a. Lipoid S100 } 200 \mathrm{mg} \\
\text { b. TFH+ sonication }\end{array}$ & $\begin{array}{l}\text { a. } 0.1 ; 0.3 ; 0.6 \\
\quad \text { b. NR } \\
\text { c. } 92 \\
\text { d. Chitosan }\end{array}$ & $135 \pm 21-190 \pm 8$ & 107 & $25.9-43.8$ & -1.6 & $0.27-0.29$ & 0.34 & NR & 16.5 & [17] \\
\hline Dicloxacillin & $\begin{array}{c}\text { a. Lipoid S100: } \\
\text { CHO:Tween-80 } \\
\text { 0.9:0.3:0.1 } \\
\text { b. TFH+sonication }\end{array}$ & $\begin{array}{l}\text { a. } 1 \\
\text { b. NR } \\
\text { c. NR } \\
\text { d. Chitosan }\end{array}$ & $263.4 \pm 19.1$ & $178.5 \pm 13.6$ & 15.7 & -12.7 & 0.411 & 0.247 & 62 & 38 & [60] \\
\hline
\end{tabular}


Table 3. Cont.

\begin{tabular}{|c|c|c|c|c|c|c|c|c|c|c|c|}
\hline \multirow{2}{*}{ Antimicrobials } & \multirow{2}{*}{$\begin{array}{l}\text { Liposomes } \\
\text { a. Composition } \\
\text { b. Preparation } \\
\text { Method }\end{array}$} & \multirow{2}{*}{$\begin{array}{l}\text { Chitosan or Chitosan Derivative } \\
\text { a. Concentration }(\% w / v) \\
\text { b. MW (kDa) } \\
\text { c. DD (\%) } \\
\text { d. Chitosan Type }\end{array}$} & \multicolumn{2}{|c|}{ Size (nm) } & \multicolumn{2}{|c|}{ Zeta Potential (mV) } & \multicolumn{2}{|c|}{ pdI } & \multicolumn{2}{|c|}{ EE } & \multirow[t]{2}{*}{ Ref } \\
\hline & & & CH-LP & UN-LP & CH-LP & UN-LP & CH-LP & UN-LP & CH-LP & UN-LP & \\
\hline $\begin{array}{c}\text { Nisin } \\
\text { Nisin silica }\end{array}$ & $\begin{array}{c}\text { a. Lecithin:CHO 20:4* } \\
\text { b. TFH+ } \\
\text { Homogenization }\end{array}$ & $\begin{array}{l}\text { a. } 0.1 \\
\text { b. NR } \\
\text { c. NR } \\
\text { d. Chitosan }\end{array}$ & $\begin{array}{l}134 \pm 1.34 \\
149 \pm 1.34\end{array}$ & NR & $\begin{array}{l}-42 \\
-44 \\
\end{array}$ & NR & $\begin{array}{l}0.27 \\
0.283\end{array}$ & NR & $\begin{array}{l}60 \\
72\end{array}$ & NR & [71] \\
\hline \multirow[t]{2}{*}{ Triazavirin } & \multirow[t]{2}{*}{$\begin{array}{l}\text { a. SPC:CHO } 85: 15 \text { * } \\
\text { b. TFH+ extrusion }\end{array}$} & $\begin{array}{c}\text { a. } 0.275 \\
\text { b. } 190 \\
\text { c. } 95 \\
\text { d. Pelargonic chitosan }\end{array}$ & $188 \pm 3$ & $147 \pm 3$ & 20.4 & 30.2 & 0.16 & 0.13 & NR & 77.9 & \multirow[b]{2}{*}{ [29] } \\
\hline & & $\begin{array}{c}\text { a. } 0.275 \\
\text { b. } 190 \\
\text { c. } 95 \\
\text { d. Lauric chitosan }\end{array}$ & $192 \pm 4$ & $147 \pm 3$ & 18.9 & 30.2 & 0.18 & 0.13 & NR & 77.9 & \\
\hline $\begin{array}{l}\text { Vancomycin } \\
\text { hydrochloride }\end{array}$ & $\begin{array}{c}\text { a. Lecithin: } \mathrm{CHO} 32.5: 5 \\
* \\
\text { b. REV }\end{array}$ & $\begin{array}{l}\text { a. } 0.4 \\
\text { b. NR } \\
\text { c. NR } \\
\text { d. Chitosan }\end{array}$ & $220.4 \pm 3.6$ & NR & 25.7 & NR & 0.21 & NR & 32.6 & 40 & [56] \\
\hline
\end{tabular}

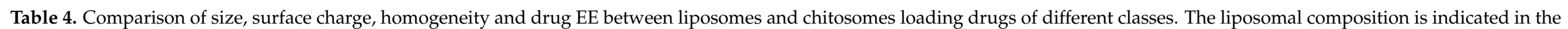
table in molar ratio except when * exists, indicating a weight ratio $(w / w)$.

\begin{tabular}{|c|c|c|c|c|c|c|c|c|c|c|c|}
\hline \multirow{2}{*}{ Drugs } & \multirow{2}{*}{$\begin{array}{l}\text { Liposomes } \\
\text { a. Composition } \\
\text { b. Preparation } \\
\text { Method }\end{array}$} & \multirow{2}{*}{$\begin{array}{c}\text { Chitosan or Chitosan Derivative } \\
\text { a. Concentration }(\% w / v) \\
\text { b. MW (kDa) } \\
\text { c. DD (\%) } \\
\text { d. Chitosan Type }\end{array}$} & \multicolumn{2}{|c|}{ Size (nm) } & \multicolumn{2}{|c|}{ Zeta Potential (mV) } & \multicolumn{2}{|c|}{ pdI } & \multicolumn{2}{|c|}{$\mathrm{EE}$} & \multirow[t]{2}{*}{ Ref } \\
\hline & & & CH-LP & UN-LP & CH-LP & UN-LP & CH-LP & UN-LP & CH-LP & UN-LP & \\
\hline Atenolol & $\begin{array}{c}\text { a. Lipoid S100 } 20 \mathrm{mg} \\
\text { b. EIM }\end{array}$ & $\begin{array}{l}\text { a. } 0.1 ; 0.6 \\
\text { b. NR } \\
\text { c. NR } \\
\text { d. Chitosan }\end{array}$ & $240 \pm 4-250 \pm 1.2$ & $89 \pm 3.5$ & 27 & -20 & NR & 0.223 & $\begin{array}{c}24.6- \\
25.7\end{array}$ & 21.6 & [63] \\
\hline
\end{tabular}


Table 4. Cont.

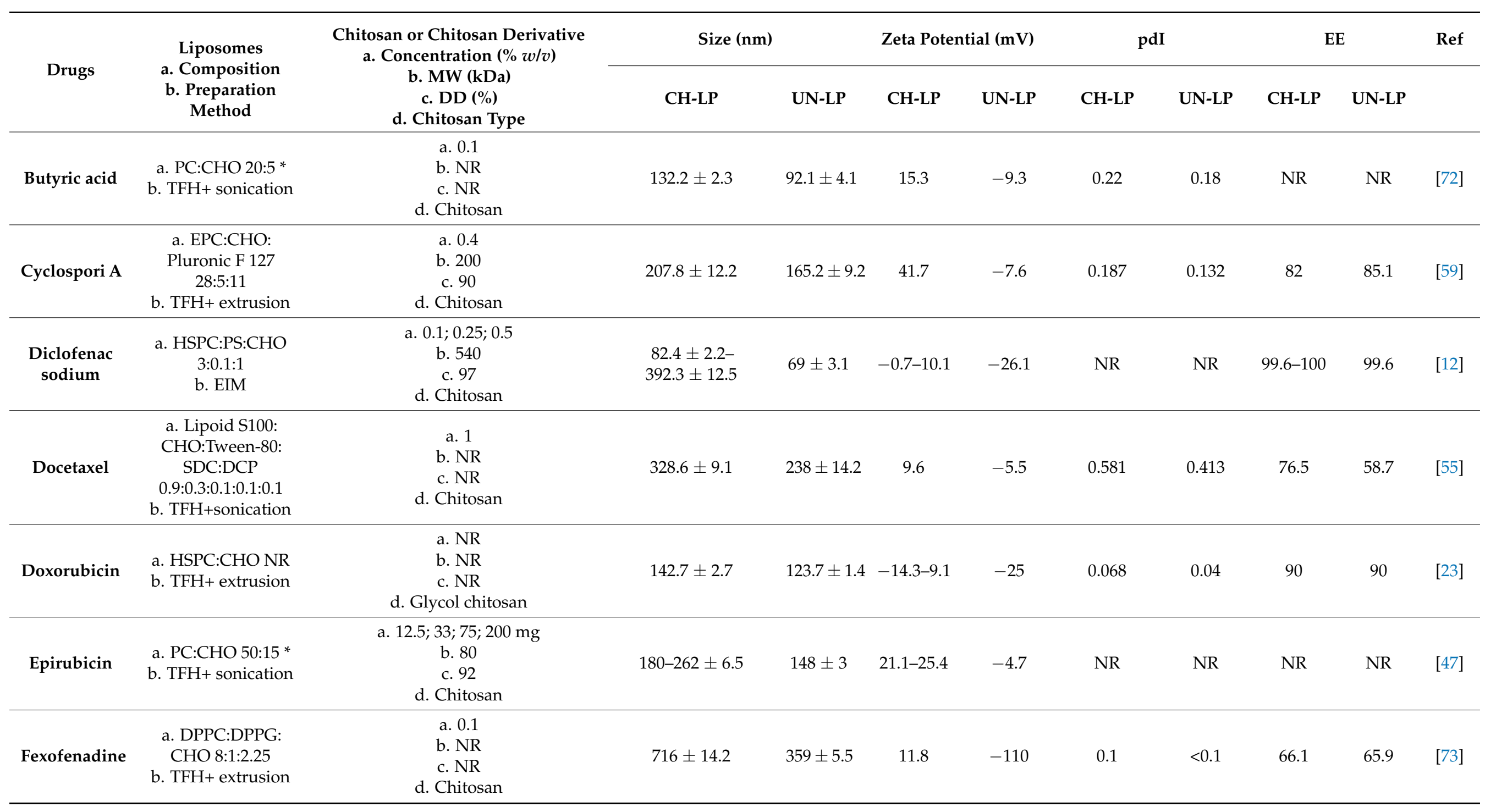


Table 4. Cont.

\begin{tabular}{|c|c|c|c|c|c|c|c|c|c|c|c|}
\hline \multirow{2}{*}{ Drugs } & \multirow{2}{*}{$\begin{array}{l}\text { Liposomes } \\
\text { a. Composition } \\
\text { b. Preparation } \\
\text { Method }\end{array}$} & \multirow{2}{*}{$\begin{array}{c}\text { Chitosan or Chitosan Derivative } \\
\text { a. Concentration }(\% \text { w/v) } \\
\text { b. MW (kDa) } \\
\text { c. DD (\%) } \\
\text { d. Chitosan Type }\end{array}$} & \multicolumn{2}{|c|}{ Size (nm) } & \multicolumn{2}{|c|}{ Zeta Potential (mV) } & \multicolumn{2}{|c|}{ pdI } & \multicolumn{2}{|c|}{$\mathrm{EE}$} & \multirow[t]{2}{*}{ Ref } \\
\hline & & & CH-LP & UN-LP & CH-LP & UN-LP & CH-LP & UN-LP & CH-LP & UN-LP & \\
\hline Flurbiprofen & $\begin{array}{c}\text { a. EPC:solutol HS15 } \\
7.5: 1 \\
\text { b. Modified EIM }\end{array}$ & $\begin{array}{l}\text { a. } 0.05 ; 0.1 ; 0.2 \\
\text { b. } 50 \\
\text { c. } 95 \\
\text { d. Chitosan }\end{array}$ & $\begin{array}{l}123.3 \pm 1.7- \\
213.9 \pm 16.5\end{array}$ & $107.7 \pm 2.8$ & $8.4-28.6$ & -22.9 & NR & NR & $\begin{array}{l}90.2- \\
92.5\end{array}$ & 85.5 & [61] \\
\hline Furosemide & $\begin{array}{c}\text { a. SPC:CHO 10:1 } \\
\text { b. TFH+ sonication }\end{array}$ & $\begin{array}{l}\text { a. } 0.5 \\
\text { b. NR } \\
\text { c. NR } \\
\text { d. Chitosan }\end{array}$ & $115.4 \pm 2.86$ & $49.8 \pm 0.85$ & 32.4 & -13.5 & NR & NR & 71.1 & 42.6 & [4] \\
\hline Lidocaine & $\begin{array}{l}\text { a. Lecithin:SDC 15\% } \\
* \\
\text { b. TFH+ sonication+ } \\
\text { extrusion }\end{array}$ & $\begin{array}{c}\text { a. } 0.1-0.5 \\
\text { b. } 150 \\
\text { c. } 90 \\
\text { d. Chitosan }\end{array}$ & $\begin{array}{c}202 \pm 9.7- \\
468.6 \pm 14.4\end{array}$ & $178.6 \pm 10.6$ & $\begin{array}{l}-12.2- \\
46.6\end{array}$ & -30.3 & $0.19-0.94$ & 0.26 & $\begin{array}{l}42.7- \\
80.2\end{array}$ & 82.3 & [48] \\
\hline Paclitaxel & $\begin{array}{c}\text { a. Lecithin:CHO: } \\
\text { SA:polyacrylic acid } \\
\text { 1.225:0.575:0.1* } \\
\text { b. TFH+sonication }\end{array}$ & $\begin{array}{l}\text { a. } 0.1 \\
\text { b. } 50 \\
\text { c. NR } \\
\text { d. Chitosan }\end{array}$ & $215 \pm 17$ & $152 \pm 12$ & 27.9 & -37.6 & NR & NR & 70.9 & 77.1 & [74] \\
\hline Prednisolone & $\begin{array}{l}\text { a. SPC:CHO 6:3* } \\
\text { b. TFH+ sonication }\end{array}$ & $\begin{array}{l}\text { a. } 2 \\
\text { b. NR } \\
\text { c. NR } \\
\text { d. Chitosan }\end{array}$ & $235.8 \pm 0.1$ & $99.9 \pm 0.2$ & 35.3 & -33.1 & NR & NR & 92.8 & 94.2 & [58] \\
\hline
\end{tabular}




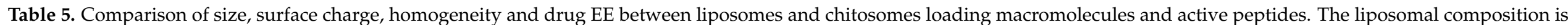
indicated in the table in molar ratio except when * exists, indicating a weight ratio $(w / w)$.

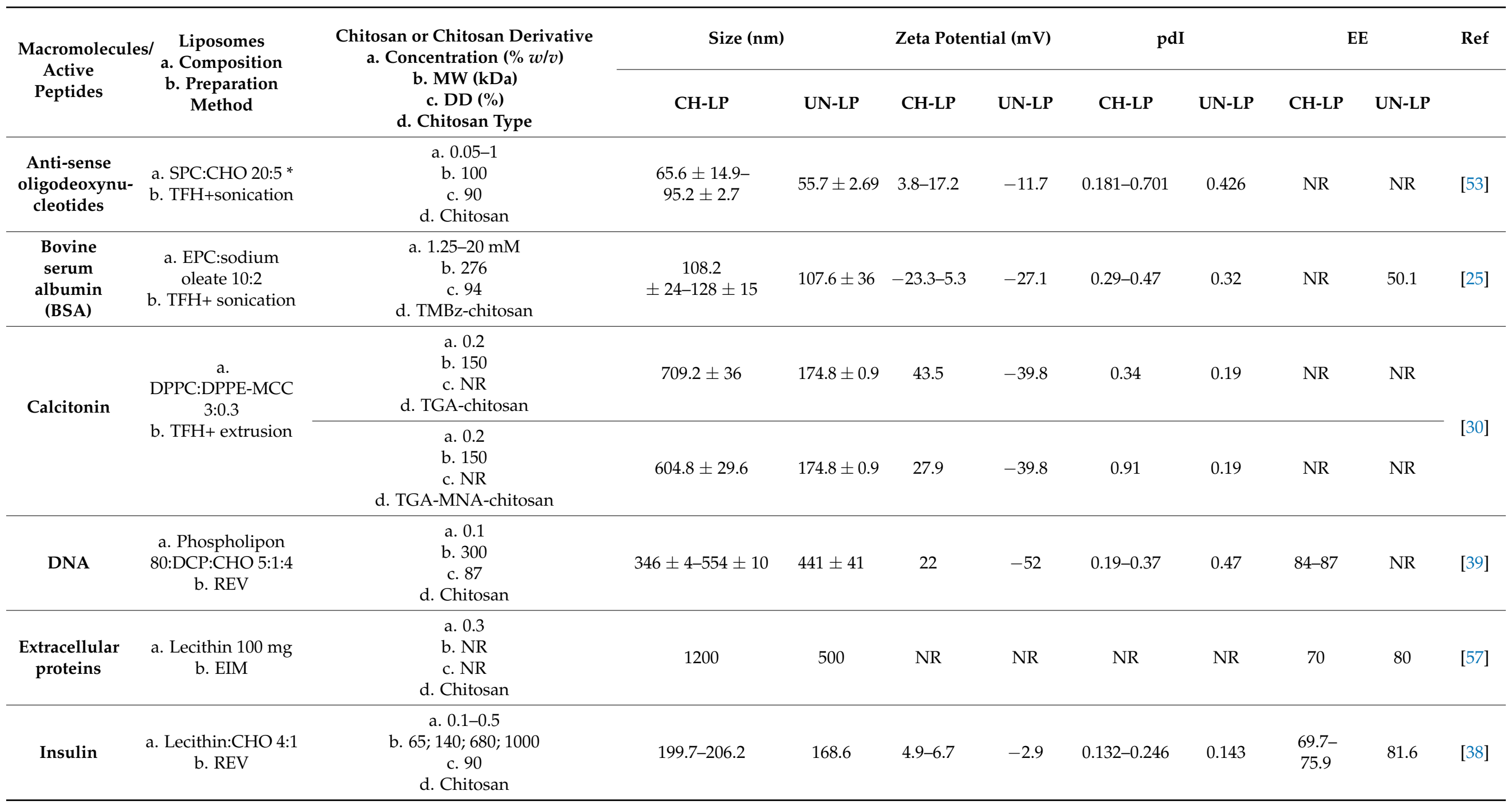


Table 5. Cont.

\begin{tabular}{|c|c|c|c|c|c|c|c|c|c|c|c|}
\hline \multirow{2}{*}{$\begin{array}{c}\text { Macromolecules/ } \\
\text { Active } \\
\text { Peptides }\end{array}$} & \multirow{2}{*}{$\begin{array}{l}\text { Liposomes } \\
\text { a. Composition } \\
\text { b. Preparation } \\
\text { Method }\end{array}$} & \multirow{2}{*}{$\begin{array}{c}\text { Chitosan or Chitosan Derivative } \\
\text { a. Concentration }(\% w / v) \\
\text { b. MW (kDa) } \\
\text { c. DD (\%) } \\
\text { d. Chitosan Type }\end{array}$} & \multicolumn{2}{|c|}{ Size $(\mathrm{nm})$} & \multicolumn{2}{|c|}{ Zeta Potential (mV) } & \multicolumn{2}{|c|}{ pdI } & \multicolumn{2}{|c|}{ EE } & \multirow[t]{2}{*}{ Ref } \\
\hline & & & CH-LP & UN-LP & CH-LP & UN-LP & CH-LP & UN-LP & CH-LP & UN-LP & \\
\hline \multirow{2}{*}{ Leuprolide } & $\begin{array}{l}\text { a. Epikuron 170: } \\
\text { CHO 6:1 }\end{array}$ & $\begin{array}{l}\text { a. } 0.1 ; 0.2 ; 0.5 ; 1 \\
\text { b. } 1000\end{array}$ & $60-140$ & 15 & $10-40$ & -29.6 & \multirow{2}{*}{ NR } & \multirow{2}{*}{ NR } & 62.4 & 73.1 & \multirow{2}{*}{40} \\
\hline & $\begin{array}{c}6: 1 \text { * } \\
\text { a. TFH+sonication }\end{array}$ & $\begin{array}{c}\text { c. }>90 \\
\text { d. Chitosan }\end{array}$ & $75-120$ & 54 & $5-20$ & 5 & & & 49.1 & 58.5 & \\
\hline $\begin{array}{l}\text { Salmon } \\
\text { protein hy- } \\
\text { drolysates }\end{array}$ & $\begin{array}{l}\text { a. MFGM Phosphlac } \\
7003 ; 5 ; 10 \%(w / v) \\
\text { b. Heating+ } \\
\text { Homogenization }\end{array}$ & $\begin{array}{l}\text { a. } 0.2-0.6 \\
\text { b. NR } \\
\text { c. NR } \\
\text { d. Chitosan }\end{array}$ & 200 & 100 & 40 & -55 & $0.2-0.7$ & $<0.19$ & $40-70$ & NR & {$[49$} \\
\hline $\begin{array}{l}\text { siRNA- } \\
\text { H1F1- } \alpha \\
\text { siRNA- } \\
\text { VEGF }\end{array}$ & $\begin{array}{c}\text { a. HSPC:DCP: CHO } \\
\text { 1:0.1:1 } \\
\text { b. TFH+ sonication }\end{array}$ & $\begin{array}{c}\text { a. } 1 \\
\text { b. } 75 \\
\text { c. } 75-85 \\
\text { d. Chitosan }\end{array}$ & $\begin{array}{l}641.7 \pm 25.2 \\
609.4 \pm 69.6\end{array}$ & $\begin{array}{l}167 \pm 14.9 \\
159.3 \pm 15.1\end{array}$ & $\begin{array}{c}24.1 \\
27\end{array}$ & $\begin{array}{l}-23.1 \\
-24.1\end{array}$ & NR & NR & NR & NR & {$[75]$} \\
\hline
\end{tabular}




\subsubsection{Physical Stability: Mechanism Controlled By Chitosan Concentration}

Stability studies were conducted to compare the size, homogeneity, zeta potential and drug EE for both conventional liposomes and chitosomes in aqueous suspension. Many studies (Table 6) reported similar stability for both systems without significant changes in their physicochemical characteristics. By comparing the liposomal composition, the presence of saturated phospholipids $[12,73,76]$ and the addition of cholesterol $(40 \%$ $\mathrm{mol}$ ) lead to a decrease in both bilayer hydration and effective size of the polar head group. Subsequently, bilayer defects are reduced, enhancing lateral packing of acyl chains, lowering thereby the leakage of liposomal contents and increasing liposomal stability. This could explain the similar stability for both systems.

However, other studies found that chitosan coating improved liposomes stability (Table 6). This is ascribed to the presence of a chitosan layer forming a wall that hinders swelling and release of encapsulated materials [5]. Second, electrostatic interaction and a weak hydrophobic force between chitosan and lipid bilayer suppressed lipid molecules mobility and kept the structural integrity of lipid membranes [44]. Moreover, the presence of surfactants like sodium oleate, dihexadecylphosphate, dicetylphosphate (DCP) or tween80 in some studies (Table 6) can explain the decrease in the liposomal stability because surfactants increase the bilayer deformability.

It is worthy to note that chitosan concentration seems to be the main factor controlling liposomal stability. Increasing chitosan concentration led to an increase in liposomal stability $[5,44]$. However, an excess of chitosan may promote the flocculation and coagulation process of the liposomes [42,45,49]. A proposed mechanism (Figure 3) explained the chitosomal stability controlled by the so-called chitosan saturation concentration, which is the minimum polymer concentration required to cover the oppositely charged particles. According to Laye's explanation [3], the addition of chitosan to the liposomes below and above the saturation concentration can both lead to liposomal dispersions destabilization. At insufficient polymer concentrations, the anionic phospholipid molecules of liposomes may be bounded to the cationic chitosan molecules to form coacervates rather than chitosan molecules wrapping themselves around the liposome surface. At excess polymer concentrations, the exclusion of polymer molecules from a narrow region surrounding the particle surfaces generates an attractive force strong enough to overcome the intermolecular repulsive forces and to bring the particles together, making the liposomes susceptible to bridging flocculation [3].

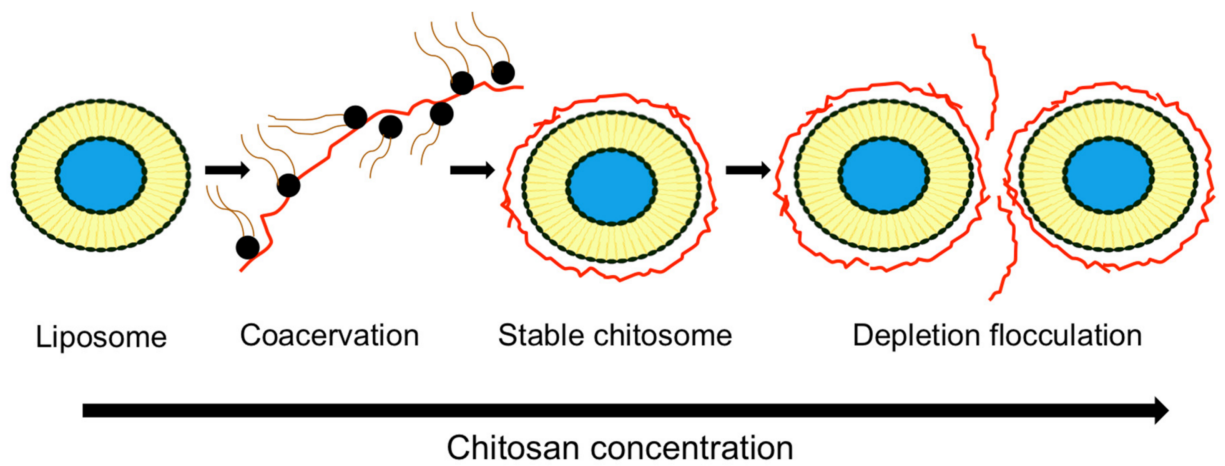

Figure 3. Proposed mechanism of liposome stability controlled by chitosan concentration.

The storage temperature influenced vesicle stability. Low-temperature achieved better stability for both systems. This could be explained by the low permeability of coating layers at refrigeration temperature, the inhibition of aggregation (low molecular mobility) and the retardation of oxidative degradation of unsaturated fatty acids of phospholipid bilayers $[5,12,48,49]$.

Physical stability of liposomes was also evaluated by measuring particle size change after freeze-drying followed by rehydration (FD-RH) (Table 6). Chitosan improved the 
stability by protecting the liposomes against severe physical stress $\left(-70{ }^{\circ} \mathrm{C}\right)[35,49]$. Using chitosan as a cryoprotectant, along with surface coating, liposomes could achieve better stability and the desired physicochemical characteristics for a prolonged duration.

Modified chitosan effect on the stability of the liposomes was investigated. The side groups introduced into the polysaccharide chains play an important role in stabilizing the liposomes [26,29], as reported in Table 6.

\subsubsection{Mechanism Controlled by Medium Composition}

Lecithin includes unsaturated double bonds, which are prone to oxidation, thus contributing to the instability of the liposomal lipid bilayers. Transition metals, such as ferrous iron, can induce oxidation in liposomes by interacting with residual lipid hydroperoxides to produce free reactive radicals [77]. The stability of liposomes and chitosomes were tested in the presence of ferrous iron in order to determine the lipid hydroperoxides formation. Being a specific volatile oxidation product of polyunsaturated fatty acids like linoleic acid, hexanal determined by gas chromatography was also used as lipid oxidation indicator. Results showed that uncoated liposomes were highly prone to lipid oxidation since the formation of hexanal and lipid hydroperoxides occurred rapidly. However, chitosan coating inhibited lipid oxidation, hence improving the oxidative stability to some extent due to its ability to repel pro-oxidants metals from the liposome surface $[68,69]$. In addition, the combination of antioxidants, such as rosmarinic acid and chitosan coating, resulted in greater inhibition of lipid oxidation in liposomes [69].

Moreover, measurement of malonaldehyde (MDA), an oxidation product of phospholipids, can give useful information regarding the stability of liposomes/chitosomes. The release of MDA was lower in the case of chitosomes encapsulating Chrysanthemum EO vs. noncoated liposomes [78]. It has been demonstrated that a chitosan coating was able to protect phospholipid membranes from oxidation during different temperature storage; still, the increase of storage temperature increased the speed of phospholipids oxidation [78]

Furthermore, conventional liposomes are sensitive to damage caused by harsh chemical and enzymatic GI environments, resulting in reduced oral bioavailability [5]. Chitosan's effect on liposome stability in simulated gastric (SGF) and intestinal (SIF) fluid is presented in Table 6. The chitosan layer improved liposomes stability in SGF [5,74], explained by enhanced interactions between chitosan and liposome surface under low pH in SGF (pH 1.2) due to amino groups protonation in chitosan (pKa 6.5). The molecular configuration of chitosan also became more expanded, leading to a stronger affinity for the liposome surface. However, chitosomes were less stable than liposomes in SIF ( $\mathrm{pH} 6.8$ ) [5,59] due to a decrease in the number of charged cationic groups in chitosan at the medium $\mathrm{pH}$, resulting in weaker electrostatic interactions between chitosan and liposomes surface, thus an increase in the diameter of the liposome. Moreover, SIF constituents, such as bile salts, act as surfactants promoting lipid solubilization for conventional liposomes and chitosomes. Pancreatic lipases have a digestive action on phospholipids, also contributing to destabilization of the liposomal system [5]. 


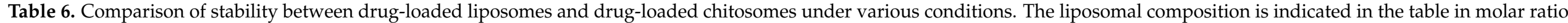
except when * exists, indicating a weight ratio $(w / w)$.

\begin{tabular}{|c|c|c|c|c|c|}
\hline Drug/EO & $\begin{array}{l}\text { Liposomes } \\
\text { a. Composition } \\
\text { b. Preparation Method }\end{array}$ & $\begin{array}{l}\text { Chitosan or Chitosan } \\
\text { Derivative } \\
\text { a. Concentration }(\% w / v) \\
\text { b. MW (kDa) } \\
\text { c. DD (\%) } \\
\text { d. Chitosan Type }\end{array}$ & $\begin{array}{l}\text { Storage Conditions } \\
\text { a. Temperature } \\
\text { b. Time } \\
\text { c. Medium }\end{array}$ & Stability: Chitosomes and Liposomes & Ref \\
\hline \multirow[t]{2}{*}{$\begin{array}{c}\text { Berberine } \\
\text { hydrochloride }\end{array}$} & \multirow{2}{*}{$\begin{array}{l}\text { a. EPC:CHO:DHP } \\
\text { 1:0.242:0.036* } \\
\text { b. TFH + sonication }\end{array}$} & \multirow{2}{*}{$\begin{array}{l}\text { a. } 0.1 ; 0.3 \\
\text { b. } N R \\
\text { c. }>90 \\
\text { d. Chitosan }\end{array}$} & $\begin{array}{l}\text { a. } 4 ; 25^{\circ} \mathrm{C} \\
\text { b. } 30 \text { days } \\
\text { c. Aqueous suspension }\end{array}$ & $\begin{array}{l}\text { - Chitosomes displayed better stability at } 4 \text {, and } 25^{\circ} \mathrm{C} \text { since } \\
\text { the changes in size, zeta potential and drug EE were less than } \\
\text { those in uncoated ones } \\
\text { - The changes in size, Zeta potential and leakage ratio at } 25 \\
{ }^{\circ} \mathrm{C} \text { for both systems were higher than that at } 4{ }^{\circ} \mathrm{C} \\
\text { - } 0.3 \% \text { chitosomes were more stable than } 0.1 \% \text { chitosomes } \\
\text { due to the thicker coating layer. }\end{array}$ & \multirow[t]{2}{*}{ [5] } \\
\hline & & & $\begin{array}{l}\text { a. } 37^{\circ} \mathrm{C} \\
\text { b. } 24 \mathrm{~h} \\
\text { c. SGF (pH 1.2); SIF (pH 7.4) }\end{array}$ & $\begin{array}{l}\text { - The changes in size and zeta potential of coated liposomes } \\
\text { were less than those for uncoated ones in SGF } \\
\text { - In SIF, uncoated liposome size increased by } 1.6 \text {-fold, while } \\
\text { that of chitosomes increased by } 6.2 \text { - and } 4.2 \text {-fold for } 0.1 \text { and } \\
0.3 \% \text { chitosan, respectively }\end{array}$ & \\
\hline $\begin{array}{l}\text { Black mulberry } \\
\text { extract }\end{array}$ & $\begin{array}{l}\text { a. Lecithin } 2 \%(w / v) \\
\text { b. Homogenization }\end{array}$ & $\begin{array}{l}\text { a. } 0.4 \\
\text { b. } \mathrm{NR} \\
\text { c. } 80 \text {. } \\
\text { d. Chitosan }\end{array}$ & $\begin{array}{l}\text { a. } 37^{\circ} \mathrm{C} \\
\quad \text { b. } 2 \mathrm{~h} \\
\text { c. SGF (pH 2) }\end{array}$ & $\begin{array}{c}\text { - The percentage recovery of anthocyanins in chitosomes } \\
(3.7 \%) \text { was higher than that in liposomes }(2.1 \%) \text { after } \\
\text { incubation in SGF }\end{array}$ & [65] \\
\hline BSA & $\begin{array}{l}\text { a. EPC:sodium oleate } 10: 2 \\
\text { b. TFH + sonication }\end{array}$ & $\begin{array}{c}\text { a. } 20 \mathrm{mM} \\
\text { b. } 276 \\
\text { c. } 94 \\
\text { d. TMBz-chitosan }\end{array}$ & $\begin{array}{l}\text { a. } 37^{\circ} \mathrm{C} \\
\text { b. } 60 \mathrm{~min} \\
\text { c. } \operatorname{SIF}(\mathrm{pH} 7.5)\end{array}$ & $\begin{array}{c}\text { - TMBz chitosan-coated liposomes protected BSA from } \\
\text { pancreatin degradation in SIF more than conventional } \\
\text { liposomes due to the interaction between positively charged } \\
\text { derivative and negatively charged BSA }\end{array}$ & [25] \\
\hline Calcitonin & $\begin{array}{l}\text { a. DSPC:CHO: DCP 8:1:2 } \\
\text { b. TFH + extrusion }\end{array}$ & $\begin{array}{c}\text { a. } 0.6 \\
\text { b. } 150 ; 22 \\
\text { c. }>85 ; 80 \\
\text { d. } \text { Chitosan }\end{array}$ & $\begin{array}{c}\text { a. } 37^{\circ} \mathrm{C} \\
\text { b. } 60 \mathrm{~min} \\
\text { c. Tris-HCl buffer (pH 8) }\end{array}$ & $\begin{array}{l}\text { - LMW chitosomes had more efficiency to protect calcitonin } \\
\text { from trypsin degradation than HMW chitosomes }\end{array}$ & [54] \\
\hline
\end{tabular}


Table 6. Cont.

\section{Drug/EO a. Composition} b. Preparation Method

\section{Chitosan or Chitosan \\ Derivative}

a. Concentration $(\% w / v)$

b. MW (kDa)

c. DD (\%)

d. Chitosan Type

\section{Carotenoids:}

lutein;

$\beta$-carotene;

lycopene;

canthaxanthin
a. EPC:Tween-80 NR
b. $\mathrm{TFH}+$ sonication
a. $0.05 ; 0.1 ; 0.15$
b. 200
c. 85

d. Chitosan

\section{Storage Conditions \\ a. Temperature \\ b. Time \\ c. Medium}

Stability: Chitosomes and Liposomes

Ref

(a)

a. $0.025 ; 0.05 ; 0.075 ; 0.1$

$\begin{array}{ccc}\text { Chrysanthemum } & \text { a. Lecithin:CHO 5:1 } & \mathrm{mg} / \mathrm{mL} \\ \text { sp. } & \text { b. TFH + extrusion } & \text { b. NR } \\ & & \text { c. NR } \\ & & \text { d. Chitosan }\end{array}$

\begin{abstract}
a. EPC:CHO 2:1
\end{abstract}
a. 0.1

b. EIM and TFH + sonication

b. 30 d. Chitosan

\section{a. $37 ; 65 ; 90{ }^{\circ} \mathrm{C}$ \\ b. $390 \mathrm{~min}$}

c. Aqueous suspension
- Chitosan coating increased carotenoid retention rates in liposomes by $8-15 \%$ after coating

- When heating at 37 and $65{ }^{\circ} \mathrm{C}$, the retaining capacity of liposomes showed chitosan concentration dependency. The

higher the chitosan concentration was, the stronger the thermal resistance of chitosomes

- Whatever the heating conditions were, liposomes exhibited the strongest retaining ability to lutein, followed by $\beta$-carotene, lycopene and canthaxanthin

\begin{tabular}{|c|c|c|c|c|}
\hline \multirow{3}{*}{ Curcumin } & $\begin{array}{c}\text { a. EPC:CHO 2:1 } \\
\text { b. EIM and TFH + sonication }\end{array}$ & $\begin{array}{l}\text { a. } 0.1 \\
\text { b. } 30 \\
\text { c. } 88 \\
\text { d. Chitosan }\end{array}$ & $\begin{array}{l}\text { a. } 4 ; 25^{\circ} \mathrm{C} \\
\text { b. } 40 \text { days } \\
\text { c. Aqueous suspension }\end{array}$ & $\begin{array}{c}\text { - Both systems prepared either by EIM or TFH were stable at } \\
\text { both temperatures since no changes in mean size and pdI } \\
\text { values were observed after } 40 \text { days }\end{array}$ \\
\hline & $\begin{array}{l}\text { a. PC:CHO 5:1* } \\
\text { b. EIM }\end{array}$ & $\begin{array}{l}\text { a. } 1 \\
\text { b. } 28 \\
\text { c. } 89 \\
\text { d. Chitosan }\end{array}$ & $\begin{array}{l}\text { a. } 4 ; 25 ; 30 ; 40 ; 50 ; 60 ; 70 ; 80 \\
90^{\circ} \mathrm{C} \\
\text { b. } 40 \text { days } \\
\text { c. Aqueous suspension }\end{array}$ & $\begin{array}{l}\text { - 90.68\% of curcumin remained encapsulated in chitosomes } \\
\text { compared to } 26.03 \% \text { in liposomes after } 40 \text { days at } 4{ }^{\circ} \mathrm{C} \\
\text { - The remaining percentage of curcumin decreased to } 75.77 \% \\
\text { when chitosomes were stored at } 25^{\circ} \mathrm{C} \\
\text { - Chitosomes showed the highest remaining percentage of } \\
\text { curcumin at various temperatures tested up to } 90^{\circ} \mathrm{C} \\
\text { compared to liposomes and free curcumin }\end{array}$ \\
\hline & $\begin{array}{c}\text { a. EPC:DHP:CHO NR } \\
\text { b. NR }\end{array}$ & $\begin{array}{c}\text { a. } 0.0025 \\
\text { b. NR } \\
\text { c. } 80 \\
\text { d. Chitosan; N-dodecyl } \\
\text { chitosan; HPTMA-chitosan; } \\
\text { N-dodecyl chitosan-HPTMA }\end{array}$ & $\begin{array}{l}\text { a. NR } \\
\text { b. NR } \\
\text { c. Triton X100 pH } 7.4\end{array}$ & $\begin{array}{l}\text { - Alkyl anchors (N-dodecyl chitosan; } \mathrm{N} \text {-dodecyl } \\
\text { chitosan-HPTMA chloride) showed better stability compared } \\
\text { to native chitosan and uncoated liposomes since the } \\
\text { disruption process by triton } \mathrm{X} 100 \text { was slowed down } \\
\text { considerably in the presence of these polymers on liposomes }\end{array}$ \\
\hline
\end{tabular}

- MDA content was lower in case of EO chitosomes compared to EO loaded liposomes
$12 ; 25 ; 37^{\circ} \mathrm{C}$

c. NR

$0.68 \%$ of curcumin remained encapsulated in chitosomes

Chitosomes showed the highest remaining percentage of umin at various temperatures tested up to $90^{\circ}$

- Alkyl anchors (N-dodecyl chitosan; N-dodecyl to native chitosan and uncoated liposomes since the

disruption process by triton X100 was slowed down N-dodecyl chitosan-HPTMA 
Table 6. Cont.

\begin{tabular}{|c|c|c|c|c|c|}
\hline Drug/EO & $\begin{array}{l}\text { Liposomes } \\
\text { a. Composition } \\
\text { b. Preparation Method }\end{array}$ & $\begin{array}{l}\text { Chitosan or Chitosan } \\
\text { Derivative } \\
\text { a. Concentration }(\% \text { w/v) } \\
\text { b. MW (kDa) } \\
\text { c. DD (\%) } \\
\text { d. Chitosan Type }\end{array}$ & $\begin{array}{l}\text { Storage Conditions } \\
\text { a. Temperature } \\
\text { b. Time } \\
\text { c. Medium }\end{array}$ & Stability: Chitosomes and Liposomes & Ref \\
\hline $\begin{array}{l}\text { Diclofenac } \\
\text { sodium }\end{array}$ & $\begin{array}{l}\text { a. HSPC:PS:CHO 3:0.1:1 } \\
\text { b. EIM }\end{array}$ & $\begin{array}{l}\text { a. } 0.25 ; 0.5 \\
\quad \text { b. } 540 \\
\quad \text { c. } 97 \\
\text { d. Chitosan }\end{array}$ & $\begin{array}{l}\text { a. } 4 ; 25^{\circ} \mathrm{C} \\
\text { b. } 30 \text { days } \\
\text { c. Aqueous suspension }\end{array}$ & $\begin{array}{l}\text { - Both chitosomes and liposomes were stable at } 4{ }^{\circ} \mathrm{C} \text { without } \\
\text { significant changes in their size, Zeta potential and EE } \\
\text { - At } 25^{\circ} \mathrm{C} \text {, chitosomes with both concentrations used showed } \\
\text { better stability than liposomes in terms of size and EE }\end{array}$ & [12] \\
\hline DNA & $\begin{array}{l}\text { a. Phospholipon } \\
\text { 80:DCP:CHO 5:1:4 } \\
\text { b. REV }\end{array}$ & $\begin{array}{l}\text { a. } 0.1 \\
\text { b. } 300 \\
\text { c. } 87 \\
\text { d. Chitosan }\end{array}$ & $\begin{array}{c}\text { a. } 37^{\circ} \mathrm{C} \\
\text { b. } 1,2 \mathrm{~h} \\
\text { c. } \mathrm{SGF}(\mathrm{pH} 1.2) ; \operatorname{SIF}(\mathrm{pH} 6.8)\end{array}$ & $\begin{array}{l}\text { - Chitosomes protected the DNA from the endonuclease } \\
\text { digestion after incubation in both SGF and SIF. However, } \\
\text { conventional liposomes were less protective in SIF }\end{array}$ & [39] \\
\hline Epirubicin & $\begin{array}{l}\text { a. PC:CHO } 50: 15^{*} \\
\text { b. TFH + sonication }\end{array}$ & $\begin{array}{l}\text { a. } 12.5 ; 33 ; 75 ; 200 \mathrm{mg} \\
\text { b. } 80 \\
\text { c. } 92 \\
\text { d. Chitosan }\end{array}$ & $\begin{array}{l}\text { a. } 4 ; 25 ; 37^{\circ} \mathrm{C} \\
\text { b. } 30 \text { days } \\
\text { c. Aqueous suspension }\end{array}$ & $\begin{array}{c}\text { - Chitosomes showed better stability after } 30 \text { days of storage } \\
\text { at } 4 \text { and } 25^{\circ} \mathrm{C} \text { with no significant changes in size, contrary to } \\
\text { conventional liposomes } \\
\text { - Both systems were unstable at } 37^{\circ} \mathrm{C} \text { with a significant } \\
\text { increase in vesicle size }\end{array}$ & [47] \\
\hline $\begin{array}{l}\text { Extracellular } \\
\text { proteins }\end{array}$ & $\begin{array}{l}\text { a. Lecithin } 100 \mathrm{mg} \\
\text { b. EIM }\end{array}$ & $\begin{array}{l}\text { a. } 0.3 \\
\text { b. NR } \\
\text { c. NR } \\
\text { d. Chitosan }\end{array}$ & $\begin{array}{c}\text { a. } 4^{\circ} \mathrm{C} \\
\text { b. } 60 \text { days } \\
\text { c. Aqueous suspension }\end{array}$ & $\begin{array}{c}\text { - Chitosomes improved liposome stability since more than } \\
70 \% \text { and } 50 \% \text { of extracellular proteins remained encapsulated } \\
\text { after } 2 \text { months at } 4{ }^{\circ} \mathrm{C} \text { in coated and noncoated liposomes, } \\
\text { respectively }\end{array}$ & [57] \\
\hline Fexofenadine & $\begin{array}{l}\text { a. DPPC:DPPG: CHO 8:1:2.25 } \\
\text { b. TFH+ extrusion }\end{array}$ & $\begin{array}{l}\text { a. } 0.1 \\
\text { b. NR } \\
\text { c. NR } \\
\text { d. Chitosan }\end{array}$ & $\begin{array}{l}\text { a. } 4 ; 25^{\circ} \mathrm{C} \\
\text { b. } 180 \text { days } \\
\text { c. Freeze-dried powder }\end{array}$ & $\begin{array}{l}\text { - Under different tested conditions, drug leakage was lower } \\
\text { than } 10 \% \text {, and the size change was minimal for both systems }\end{array}$ & [73] \\
\hline Glucose & $\begin{array}{l}\text { a. DPPC } 0.27 \mathrm{M} \\
\text { b. ISCRPE }\end{array}$ & $\begin{array}{l}\text { a. } 0.005 \\
\text { b. } \mathrm{NR} \\
\text { c. } 70-90 \\
\text { d. Chitosan }\end{array}$ & $\begin{array}{l}\text { a. } 25^{\circ} \mathrm{C} \\
\text { b. } 30 \text { days } \\
\text { c. Aqueous suspension }\end{array}$ & $\begin{array}{l}\text { - Both systems were stable since the loss in glucose EE from } \\
\text { chitosomes over time was almost similar to that in liposomes }\end{array}$ & [76] \\
\hline $\begin{array}{l}\text { Grape seed } \\
\text { extract }\end{array}$ & $\begin{array}{l}\text { a. Lipoid } S 751 \%(w / w) \\
\text { b. High-pressure } \\
\text { homogenizer }\end{array}$ & $\begin{array}{l}\text { a. } 0.1 \\
\text { b. } N R \\
\text { c. } 79 \\
\text { d. Chitosan }\end{array}$ & $\begin{array}{l}\text { a. } 25^{\circ} \mathrm{C} \\
\text { b. } 98 \text { days } \\
\text { c. Aqueous suspension }\end{array}$ & $\begin{array}{l}\text { - Both systems were stable since no significant changes in } \\
\text { size and zeta potential were observed }\end{array}$ & [68] \\
\hline
\end{tabular}


Table 6. Cont.

\begin{tabular}{|c|c|c|c|c|c|}
\hline \multirow[t]{2}{*}{ Drug/EO } & $\begin{array}{l}\text { Liposomes } \\
\text { a. Composition } \\
\text { b. Preparation Method }\end{array}$ & $\begin{array}{l}\text { Chitosan or Chitosan } \\
\text { Derivative } \\
\text { a. Concentration }(\% \text { w/v) } \\
\text { b. MW (kDa) } \\
\text { c. DD (\%) } \\
\text { d. Chitosan Type }\end{array}$ & $\begin{array}{l}\text { Storage Conditions } \\
\text { a. Temperature } \\
\text { b. Time } \\
\text { c. Medium }\end{array}$ & Stability: Chitosomes and Liposomes & Ref \\
\hline & & $\begin{array}{l}\text { a. } 1 \\
\text { b. } \mathrm{NR} \\
\text { c. } 79 \\
\text { d. Chitosan }\end{array}$ & $\begin{array}{c}\text { a. } 25^{\circ} \mathrm{C} \\
\text { b. } 15 \text { days } \\
\text { c. Aqueous suspension }\end{array}$ & $\begin{array}{l}\text { - Both systems were stable since no significant changes in } \\
\text { size and zeta potential were observed }\end{array}$ & [62] \\
\hline Insulin & $\begin{array}{l}\text { a. Lecithin:CHO 4:1 } \\
\text { b. REV }\end{array}$ & $\begin{array}{l}\text { a. } 0.1-0.5 \\
\text { b. } 65 ; 140 ; 680 ; 1000 \\
\text { c. } 90 \\
\text { d. Chitosan }\end{array}$ & $\begin{array}{c}\text { a. } 37^{\circ} \mathrm{C} \\
\text { b. NR } \\
\text { c. Tris-HCl buffered saline } \\
(\mathrm{pH} 2 \text { and } 7.4)\end{array}$ & $\begin{array}{l}\text { - Chitosan coating reduced peptic and tryptic digestion of } \\
\text { insulin compared to uncoated liposomes } \\
\text { - This protective action in chitosomes was enhanced by the } \\
\text { increase in chitosan MW and concentration }\end{array}$ & {$[38]$} \\
\hline Lidocaine & $\begin{array}{l}\text { a. Lecithin:SDC } 15 \% \text { * } \\
\text { b. TFH + sonication+ } \\
\quad \text { extrusion }\end{array}$ & $\begin{array}{l}\text { a. } 0.3 ; 0.5 \\
\text { b. } 150 \\
\quad \text { c. } 90 \\
\text { d. Chitosan }\end{array}$ & $\begin{array}{l}\text { a. } 4 ; 25^{\circ} \mathrm{C} \\
\text { b. } 90 \text { days } \\
\text { c. Aqueous suspension }\end{array}$ & $\begin{array}{l}\text { - Elastic chitosomes with both chitosan concentrations used } \\
\text { were more stable than uncoated ones for } 3 \text { months at } 4 \text { and } 25 \\
{ }^{\circ} \mathrm{C} \text {, where a slow increase in size and drug leakage ratio were } \\
\text { observed } \\
\text { - No significant difference in size and drug leakage ratio } \\
\text { between elastic liposomes coated with } 0.3 \text { and } 0.5 \% \text { chitosan } \\
\text { after } 3 \text { months; } \\
\text { - A better stability was obtained at } 4{ }^{\circ} \mathrm{C} \text { since the changes in } \\
\text { size and leakage ratio were less than those obtained at } 25^{\circ} \mathrm{C}\end{array}$ & [48] \\
\hline Mitoxantrone & $\begin{array}{l}\text { a. SPC:CHO 5:1 } \\
\text { b. TFH + sonication }\end{array}$ & $\begin{array}{l}\text { a. } 0.1 ; 0.3 ; 0.6 ; 1.2 \\
\text { b. } 70 \\
\text { c. } 92 \\
\text { d. Chitosan }\end{array}$ & $\begin{array}{l}\text { a. }-70{ }^{\circ} \mathrm{C} \\
\text { b. NR } \\
\text { c. FD-RH }\end{array}$ & $\begin{array}{l}\text { - Uncoated liposomes showed higher size after FD-RH } \\
\text { compared to chitosomes, indicating the protective effect of } \\
\text { chitosan-coating during FD-RH } \\
\text { - As chitosan concentration increased from } 0 \text { to } 0.3 \% \text {, } \\
\text { liposomes showed fewer changes in their size after FD-RH }\end{array}$ & [35] \\
\hline \multirow[b]{2}{*}{ Paclitaxel } & \multirow{2}{*}{$\begin{array}{l}\text { a. Lecithin:CHO:SA } \\
\text { 1.225:0.575:0.1* } \\
\text { b. TFH + sonication }\end{array}$} & \multirow{2}{*}{$\begin{array}{l}\text { a. } 0.1 \\
\text { b. } 50 \\
\text { c. NR } \\
\text { d. Chitosan }\end{array}$} & $\begin{array}{l}\text { a. } 4 ; 25^{\circ} \mathrm{C} \\
\text { b. } 180 \text { days } \\
\text { c. Aqueous suspension }\end{array}$ & $\begin{array}{l}\text { - Both systems were stable at } 4 \text { and } 25^{\circ} \mathrm{C} \text { since no significant } \\
\text { changes were observed in size, zeta potential and EE after } \\
\text { storage }\end{array}$ & \multirow[t]{2}{*}{ [74] } \\
\hline & & & $\begin{array}{c}\text { a. } 37^{\circ} \mathrm{C} \\
\text { b. } 2 \text { h, } 6 \text { h } \\
\text { c. SGF (pH 1.2); SIF (pH 6.8) }\end{array}$ & $\begin{array}{c}\text { - Chitosomes were more stable than liposomes in both SGF } \\
\text { and SIF since no changes in size, zeta potential and EE were } \\
\text { obtained }\end{array}$ & \\
\hline
\end{tabular}


Table 6. Cont.

\begin{tabular}{|c|c|c|c|c|c|}
\hline Drug/EO & $\begin{array}{l}\text { Liposomes } \\
\text { a. Composition } \\
\text { b. Preparation Method }\end{array}$ & $\begin{array}{c}\text { Chitosan or Chitosan } \\
\text { Derivative } \\
\text { a. Concentration }(\% \text { w/v) } \\
\text { b. MW (kDa) } \\
\text { c. DD (\%) } \\
\text { d. Chitosan Type }\end{array}$ & $\begin{array}{l}\text { Storage Conditions } \\
\text { a. Temperature } \\
\text { b. Time } \\
\text { c. Medium }\end{array}$ & Stability: Chitosomes and Liposomes & Ref \\
\hline Resveratrol & $\begin{array}{l}\text { a. EPC } 2 \%(w / v) \\
\text { b. TFH + sonication }\end{array}$ & $\begin{array}{l}\text { a. } 0.1 ; 0.3 ; 0.5 \\
\text { b. NR } \\
\text { c. NR } \\
\text { d. Chitosan }\end{array}$ & $\begin{array}{l}\text { a. } 25^{\circ} \mathrm{C} \\
\text { b. } 7 \text { days } \\
\text { c. Aqueous suspension }\end{array}$ & $\begin{array}{l}\text { - Chitosan improved liposomes stability since the size } \\
\text { increase after storage was lower than that of uncoated } \\
\text { liposomes } \\
\text { - } 0.1 \% \text { chitosan coating displayed very little change in size } \\
\text { compared to high chitosan concentrations }(0.3 \text { and } 0.5 \%)\end{array}$ & {$[42]$} \\
\hline $\begin{array}{l}\text { Rosmarinic acid } \\
\text { esters }\end{array}$ & $\begin{array}{l}\text { a. Lecithin } 1 \%(w / v) \\
\text { b. Homogenization }\end{array}$ & $\begin{array}{l}\text { a. } 0.2 \\
\text { b. } 205 \\
\text { c. } 91.8\end{array}$ & $\begin{array}{l}\text { a. } 55^{\circ} \mathrm{C} \\
\text { b. } 14 \text { days } \\
\text { c. } \mathrm{pH} 3\end{array}$ & $\begin{array}{l}\text { - Chitosomes were more stable than liposomes, where } \\
\text { chitosomes size increased by } 1 \text {-fold after storage compared to } \\
1.5 \text {-fold for uncoated ones }\end{array}$ & {$[69]$} \\
\hline $\begin{array}{l}\text { Salmon protein } \\
\text { hydrolysates }\end{array}$ & $\begin{array}{l}\text { a. MFGM Phosphlac } 7003 ; 5 \text {; } \\
\qquad 10 \%(w / v) \\
\text { b. Heating+ Homogenization }\end{array}$ & $\begin{array}{l}\text { a. } 0.4 ; 0.6 \\
\text { b. NR } \\
\text { c. NR } \\
\text { d. Chitosan }\end{array}$ & $\begin{array}{l}\text { a. } 4 ; 20^{\circ} \mathrm{C} \\
\text { b. } 30 \text { days } \\
\text { c. Aqueous suspension; } \\
\text { and FD-RH }\end{array}$ & $\begin{array}{l}\text { - Both systems were stable at } 4{ }^{\circ} \mathrm{C} \text { without significant } \\
\text { changes in their size } \\
\text { - A better stability at } 4{ }^{\circ} \mathrm{C} \text { for both systems. } \\
\text { - The excess of chitosan }(0.6 \%) \text { resulted in more drug loss } \\
\text { after } 1 \text { month at } 20{ }^{\circ} \mathrm{C} \text { compared to } 0.4 \% \text { chitosan } \\
\text { - Conventional liposomes exhibited larger size and higher } \\
\text { drug loss compared to chitosomes after FD-RH } \\
\text { - No significant difference in drug loss between liposomes } \\
\text { coated with either } 0.4 \text { or } 0.6 \% \text { chitosan after FD-RH }\end{array}$ & [49] \\
\hline Substance $\mathbf{P}$ & $\begin{array}{l}\text { a. Lecithin:CHO 20:3.3* } \\
\text { b. TFH+ sonication }\end{array}$ & $\begin{array}{l}\text { a. } 0.1 \\
\text { b. NR } \\
\text { c. } 88 \\
\text { d. Chitosan }\end{array}$ & $\begin{array}{c}\text { a. } 37^{\circ} \mathrm{C} \\
\text { b. } 24 \mathrm{~h} \\
\text { c. } \mathrm{PBS}(\mathrm{pH} 7.4)\end{array}$ & $\begin{array}{l}\text { - Both systems were stable since the mean size and pdI did } \\
\text { not increase over time }\end{array}$ & {$[34]$} \\
\hline Triazavirin & $\begin{array}{l}\text { a. SPC:CHO } 85: 15^{*} \\
\text { b. TFH+ extrusion }\end{array}$ & $\begin{array}{c}\text { a. } 0.275 \\
\text { b. } 190 \\
\text { c. } 95 \\
\text { d. Pelargonic chitosan }\end{array}$ & $\begin{array}{c}\text { a. } 4{ }^{\circ} \mathrm{C} \\
\text { b. } 90 \text { days } \\
\text { c. Aqueous suspension }\end{array}$ & $\begin{array}{l}\text { - Unmodified liposomes were proved to be unstable after one } \\
\text { month of storage } \\
\text { - Coating of liposomes with pelargonic chitosan extended the } \\
\text { shelf life of liposomes up to } 3 \text { months at } 4{ }^{\circ} \mathrm{C} \text { compared to } \\
\text { uncoated ones since the size and pdI was almost unchanged }\end{array}$ & [29] \\
\hline Vitamin E & $\begin{array}{l}\text { a. PC:CHO } 60: 40 \\
\text { b. Sonication }\end{array}$ & $\begin{array}{l}\text { a. } 0.1 \\
\quad \text { b. } 4 \\
\text { c. }>90 \\
\text { d. Chitosan }\end{array}$ & $\begin{array}{l}\text { a. } 4 ; 25^{\circ} \mathrm{C} \\
\text { b. } 84 \text { days } \\
\text { c. Aqueous suspension }\end{array}$ & $\begin{array}{c}\text { - After } 12 \text { weeks of storage at } 4{ }^{\circ} \mathrm{C}, 97 \% \text { of vitamin } \mathrm{E} \\
\text { remained encapsulated in chitosomes compared to } 60.76 \% \text { in } \\
\text { liposomes } \\
\text { - When chitosomes were stored at } 25{ }^{\circ} \mathrm{C} \text {, the stability of } \\
\text { vitamin E decreased to } 31.2 \%\end{array}$ & {$[70]$} \\
\hline
\end{tabular}




\subsection{Drug Release}

Studies were conducted to compare the drug release rate from conventional liposomes and chitosomes. In vitro drug release from both systems was generally performed in PBS at $\mathrm{pH} 7.4$ and $37^{\circ} \mathrm{C}$ by dialysis technique. Both liposomes and chitosomes showed a two-stage profile release, an initial rapid release followed by a sustained release. The initial burst drug release can be attributed to the immediate release of surface-associated drugs. The sustained release of encapsulated drug results from drug diffusion from lipid bilayer and the adhesive chitosan layer for chitosomes $[29,55,56,60]$. Liposomes coated with chitosan $[12,34,35,47,48,55,56,60,74,79]$ or modified chitosan [22,29] released the drug in a retarded and slower manner compared to noncoated liposomes. This was attributed to the existence of the chitosan layer, which delayed the drug diffusion into the medium $[34,35,47,55,56,60]$.

In fact, the biphasic pattern of drug release is also obtained in simulated GI fluid. The deposition of chitosan on the liposome surface displayed a lower level of drug release in both SGF and SIF compared to uncoated liposomes [5,44,49,58]. Several factors controlled the drug release rate, especially the medium composition, polymer ionization and dissolution in the medium and drug ionization depending on the medium $\mathrm{pH}$ and the $\mathrm{pKa}$ value of the drug. For example, the drug release rate from both systems was enhanced in SIF relatively to SGF due to the decrease in the protonation of amino groups of chitosan in a high-pH medium $[5,44,49]$. This confirmed the mechanism by which the medium composition affects the vesicle stability described previously (Section 3.6.2 mechanism controlled by medium composition) and subsequently the drug release rate. Otherwise, the aqueous solubility of chitosan and its derivatives depends on the $\mathrm{pH}$ of the buffer solution. Since the octadecyl-quaternized lysine-modified chitosan derivative is much easier dissolved in acidic solution [22], the calcein release rate from octadecyl-quaternized lysine-modified chitosomes is higher at low $\mathrm{pH} 5.7(90 \%$ after $14 \mathrm{~h})$ than that at $\mathrm{pH} 8(70 \%)$. In addition, due to the dissolution of N-trimethyl chitosan chloride in water, and a relatively weak electrostatic interaction between liposome and polymers, a similar curcumin release profile was demonstrated between uncoated and $\mathrm{N}$-trimethyl chitosan-coated liposomes [27].

Moreover, the in vitro release data of grape-seed polyphenols performed in acetate buffer at $\mathrm{pH} 3.8$ at $25{ }^{\circ} \mathrm{C}$ [62], quercetin performed in acetate buffer at $\mathrm{pH} 5.5$ and PBS $\mathrm{pH} 7.4$ [80], and curcumin in PBS pH 7 at $23{ }^{\circ} \mathrm{C}$ and $60^{\circ} \mathrm{C}$ [66] from the liposomes and chitosomes were analyzed using various mathematical models, including the zero-order equation, first-order, Baker-Lonsdale, Higuchi, Hixson-Crowell or Korsmeyer-Peppas models to determine the kinetics and the mechanism of drug release from different formulations. The regression analysis was performed, and the model that best fit the release data was chosen on the basis of the highest correlation coefficient $R^{2}[62,80]$. The models of controlled release mechanisms for the liposomes coated with chitosan are in agreement with the release behavior of uncoated liposomes. The Korsmeyer-Peppas model was reported as the optimal model for the different formulations containing quercetin [80]. In contrast, the coefficients of correlation were equal for both Higuchi and Peppas equations $\left(R^{2}=0.972\right)$ for uncoated and chitosan-coated liposomal formulations containing grapeseed polyphenols [62]. In addition, the release of curcumin from liposomes and chitosomes mostly followed the Higuchi model at $23{ }^{\circ} \mathrm{C}$ and the Peppas model at $60{ }^{\circ} \mathrm{C}$ [66]. It is important to mention that both Higuchi and Peppas equations indicate a diffusion-driven release of drugs from uncoated and coated liposomes. In addition, the diffusional exponent $n$ determined from Korsmeyer-Peppas model indicates the mechanism of drug release, where a value of $n$ equal 0.45 (or 0.5 in some studies [62]), indicates a Fickian diffusion, while a value of $n$ between 0.45 and 0.89 indicates a non-Fickian (anomalous) release, which refers to a combination of both diffusion and erosion of the polymeric chain. When $n \geq 0.89$, the release by the erosion of polymeric chain is the major mechanism [80]. The diffusional exponent $n$ was 0.74 and 0.61 for uncoated and chitosan-coated liposomes loading quercetin, respectively [80], and in the range of 0.64 and 0.81 for both systems loading curcumin at both temperatures $\left(23\right.$ and $\left.60^{\circ} \mathrm{C}\right)$ [66], indicating an anomalous re- 
lease of quercetin [80] and curcumin [66]. However, a Fickian diffusion was reported for polyphenols from chitosomes $(n=0.502)$, while an anomalous transport from uncoated liposomes $(n=0.518)$ [62]. When an ionic polymer, such as positively charged chitosan, interacts with a released compound having an opposite charge, such as gallic acid, this results in retention via ionic bonds. This can be the reason for the difference in the release behavior of coated and uncoated liposomes [62].

Other factors, such as polymer concentration, chitosan MW and temperature, also influenced the drug release behavior. Increasing the concentration of chitosan from 0.1 to $0.6 \% w / v[5,17,37]$ or modified chitosan from 0.05 to $0.4 \%$ [22] resulted in a decrease in drug release percentage compared to uncoated liposomes. The thicker coatings ( 0.3 and $0.6 \% w / v)$ cause an obstacle for drug release [17]. It was also demonstrated that the drug release rate was not affected when chitosan content reaches saturation. Thus, no significant difference in lidocaine release profile was obtained from 0.3 and $0.5 \% w / v$ chitosan-coated elastic liposomes [48].

Additionally, a high MW of chitosan-coated liposomes showed a slower release rate of cyclosporine A than that obtained with a low MW of chitosan-coated liposomes [79] as a stronger outer coating membrane forms with a high MW of polymers.

Another factor influencing the release was the temperature. Temperature increase from 23 to $60{ }^{\circ} \mathrm{C}$ resulted in a fast curcumin release rate from both curcumin-loaded liposomes and chitosomes with a low release rate obtained in chitosomes at tested temperatures [66].

\subsection{Pharmacokinetic Studies: Conventional Liposomes and Chitosomes}

The pharmacokinetic parameters $\left(\mathrm{T}_{\max }, \mathrm{C}_{\max }, \mathrm{AUC}, \mathrm{T}_{1 / 2}\right)$ of many drugs obtained by in vivo studies were improved for chitosan-coated liposomes compared to free drug or drug-loaded conventional liposomes (Table 7). Chitosomes showed the greatest absorption, the slowest elimination, longer retention time, and enhanced bioavailability compared to drug-loaded liposomes. 


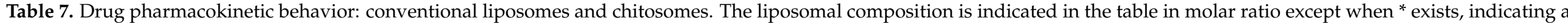
weight ratio $(w / w)$.

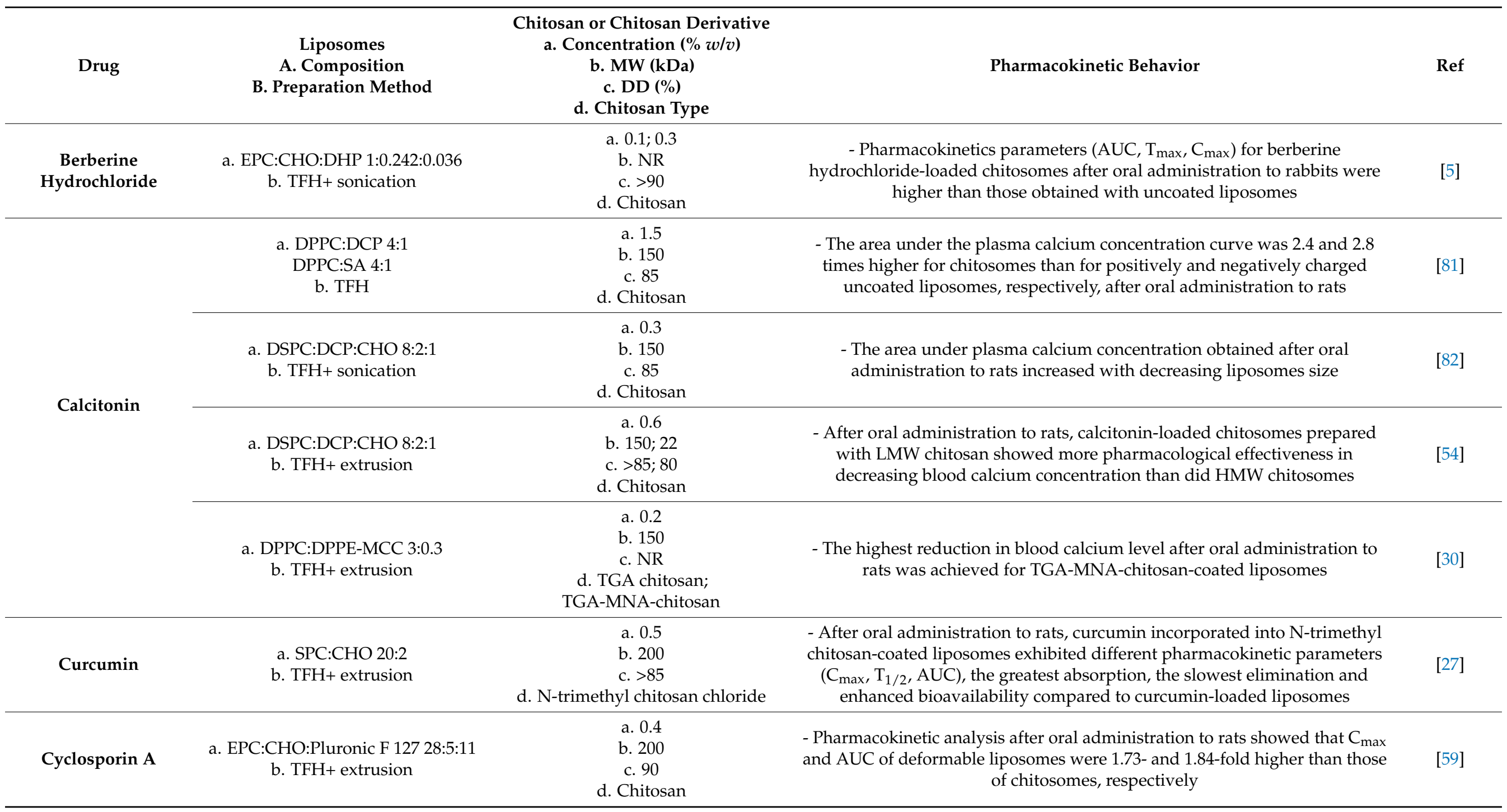


Table 7. Cont.

\begin{tabular}{|c|c|c|c|c|}
\hline Drug & $\begin{array}{l}\text { Liposomes } \\
\text { A. Composition } \\
\text { B. Preparation Method }\end{array}$ & $\begin{array}{l}\text { Chitosan or Chitosan Derivative } \\
\text { a. Concentration }(\% \text { w/v) } \\
\text { b. MW (kDa) } \\
\text { c. DD (\%) } \\
\text { d. Chitosan Type }\end{array}$ & Pharmacokinetic Behavior & Ref \\
\hline Docetaxel & $\begin{array}{l}\text { a. Lipoid S100:CHO: } \\
\text { Tween-80:SDC:DCP } \\
0.9: 0.3: 0.1: 0.1: 0.1 \\
\text { b. TFH+ sonication }\end{array}$ & $\begin{array}{l}\text { a. } 1 \\
\text { b. NR } \\
\text { c. NR } \\
\text { d. Chitosan }\end{array}$ & $\begin{array}{c}\text { - After intraperitoneal administration to rats, the pharmacokinetic } \\
\text { parameters (AUC, } C_{\max } \text {, mean residence time) were higher in deformable } \\
\text { chitosomes than in deformable liposomes }\end{array}$ & [55] \\
\hline Fexofenadine & $\begin{array}{l}\text { a. DPPC:DPPG:CHO 8:1:2.25 } \\
\text { b. TFH+ extrusion }\end{array}$ & $\begin{array}{l}\text { a. } 0.1 \\
\text { b. NR } \\
\text { c. NR } \\
\text { d. Chitosan }\end{array}$ & $\begin{array}{l}\text { - Bioavailability of fexofenadine was increased up to } 34.7 \% \text { via intranasal } \\
\text { administration of chitosomes in rats compared to uncoated liposomes }(24.5 \%)\end{array}$ & [73] \\
\hline $\begin{array}{l}\text { Vancomycin } \\
\text { hydrochloride }\end{array}$ & $\begin{array}{l}\text { a. Lecithin: } \mathrm{CHO} 32.5: 5 \text { * } \\
\text { b. REV }\end{array}$ & $\begin{array}{l}\text { a. } 0.4 \\
\text { b. NR } \\
\text { c. NR } \\
\text { d. Chitosan }\end{array}$ & $\begin{array}{c}\text { - After intravenous injection to mice, chitosomes loading vancomycin } \\
\text { hydrochloride showed a longer retention time and higher AUC values } \\
\text { compared to vancomycin hydrochloride injection and vancomycin } \\
\text { hydrochloride-loaded liposomes }\end{array}$ & [56] \\
\hline
\end{tabular}




\subsection{Pharmacodynamics: Conventional Liposomes and Chitosomes}

In the section below, the in vitro and in vivo biological effects of drug- or EO-loaded chitosomes and liposomes are reported (Tables 8-12). Chitosan-coating of liposomes improved numerous biological activities, including antimicrobial activity, mucoadhesive property, cytotoxic effect against cancer cell lines, anti-inflammatory, analgesic and suppression of gene expression.

\subsubsection{Antimicrobial Property}

Although humans developed medications for many contagious diseases, the antimicrobial and antiviral activities of synthetic and natural substances still attract much attention. In the area of antibiotic resistance, new antimicrobials are highly desired but not easy to obtain. Therefore, efforts are undertaken to increase or tailor antimicrobial activity by formulations. The antimicrobial properties of chitosan alone or blended with other natural polymers are well-known. Its activity against Gram-positive and Gram-negative bacteria results from the polycationic structure of chitosan [19]. In addition, chitosomes, even nonloaded with any drug, can exert antimicrobial activity, which was proven for Staphylococcus epidermidis and Staphylococcus aureus. The activity was dependent on the type of bacteria and the formulation, and S. epidermidis was susceptible to lower concentrations of chitosan $(0.03 \%, 0.1 \%$ and $0.3 \%)$ [83]. For this reason, antimicrobial activity measured for chitosomes loaded with drugs can be considered as a synergistic activity of the drug itself and chitosan. What is more, chitosomes are able to assure the prolonged release of the drug, as it was shown for metronidazole. The antimicrobial efficacy of chitosomes combined with the antifungal potential of the entrapped metronidazole was effective against Candida albicans and could offer improved efficacy in the treatment of mixed or complex vaginal infections [84]. Similar enhanced controlled release and antimicrobial effects against multidrug-resistant foodborne pathogens were observed for nisin entrapped in chitosomes. The inhibition of S. aureus, Enterococcus faecalis and Listeria monocytogenes growth were better for nisin-loaded chitosomes than free or liposomal-nisin [85]. The findings indicate the possible applications of chitosomes as external use antimicrobial formulations.

It was established for the first time that polymer-coating could enhance the stability of the liposomal formulations entrapping EOs, this study being a stepping-stone in the development of EOs as antimicrobial agents [36]. Thus, Artemisia afra, Eucalyptus globulus and Melaleuca alternifolia EOs were encapsulated within polymeric liposomal systems. First, synergistic to additive interactions were shown for E. globulus and M. alternifolia liposomal formulations against Escherichia coli, Staphylococcus aureus, Pseudomonas aeruginosa and Candida albicans. Further, chitosan-coating of the liposomes improved their surface stability and prolonged the EOs release, thus extending their antimicrobial activity [36]. The antimicrobial activity of EOs and other bioactive molecules in both systems is summarized in Table 8. 


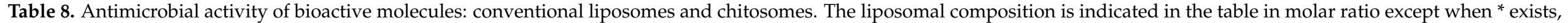
indicating a weight ratio $(w / w)$.

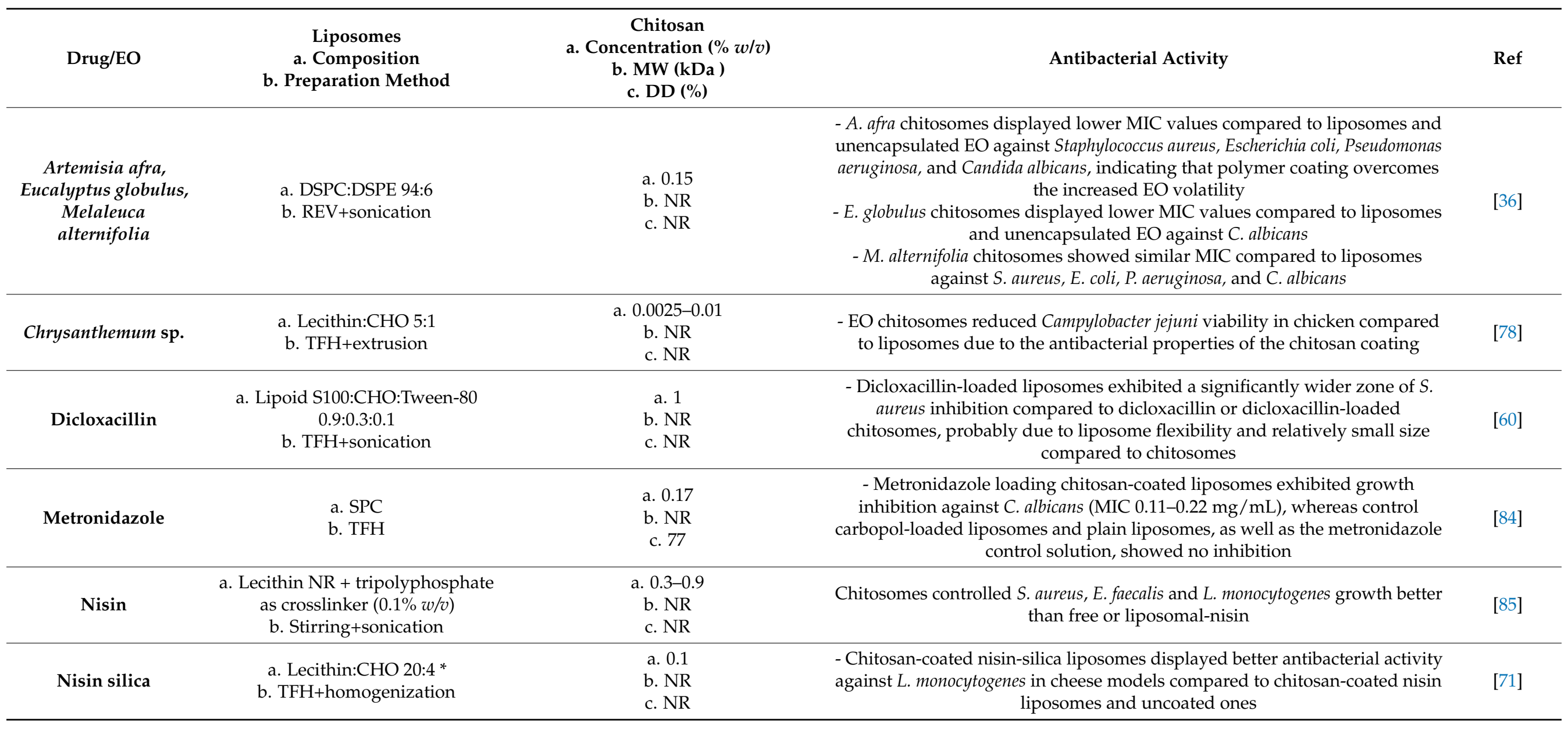




\subsubsection{Mucoadhesive Property}

The mucoadhesive property of chitosomes was the most studied one among other activities. It was carried out in vitro by incubating a mucin solution with a liposomal or chitosomal suspension at $37^{\circ} \mathrm{C}$ for $1 \mathrm{~h}$. Using a colorimetric method, the amount of free mucin in the supernatant obtained by centrifugation of the suspension is used to calculate the amount of adsorbed mucin on particle surface from the difference between total and free mucin. Mucin adsorption percent was then calculated as the ratio between the adsorbed mucin and the total amount of mucin used. Mucoadhesivity was also performed in vivo, where the liposomal or chitosomal suspension was administered orally to rats. The intestinal were removed from scarified rats and divided into segments (duodenum, jejunum and ileum). Confocal laser scanning microscopy was performed to visualize the mucopenetrative behaviors of liposomes across the intestinal mucosa. Mucus is a viscous coating on many epithelial surfaces and consists mainly of water (up to 95\% weight), inorganic salts, carbohydrates, lipids and glycoproteins, termed mucins. Mucins are hydrosoluble and responsible for the gel-like properties of mucus [86]. The mucoadhesive property of chitosomes is mainly due to the electrostatic interaction between the amine group $\left(\mathrm{NH}_{3}{ }^{+}\right)$of chitosan and the carboxylate $\left(\mathrm{COO}^{-}\right)$or sulfonate $\left(\mathrm{SO}_{3}{ }^{-}\right)$group of mucin [43] as well as by other non-covalent bonds, such as hydrogen and hydrophobic bonds (from the remaining acetyl group on chitosan molecules) [54]. Several factors, such as zeta potential, liposomes size, the polymer used, chitosan concentration and chitosan MW, may influence the chitosome's mucoadhesive property. A linear correlation was demonstrated between the mucin percent absorbed on the vesicles and their corresponding zeta potential values (Figure 4) [32].

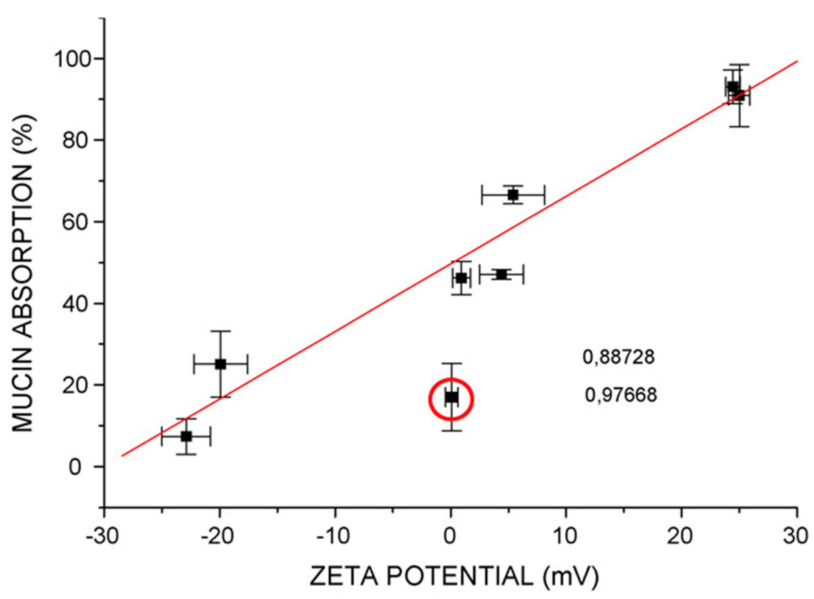

Figure 4. Effect of vesicle zeta potential on the mucoadhesive properties of chitosomes [32].

Small chitosome size showed high mucoadhesion [82]. Low chitosan concentration also favors mucoadhesivity [17]. In order for mucoadhesion to take place, the wetting and swelling of the polymer should enable an intimate contact with the mucosal tissue, followed by the interpenetration of the polymer chains and entanglement between the polymer and mucin chains [17]. Thiolated chitosans have stronger mucoadhesive properties than non-modified chitosan $[17,30]$. However, excessive water uptake will lead to overhydration forming slippery mucilage and less adhesiveness [87]. The slow swelling behavior of S-protected thiomers via conjugation of thiolated chitosan with 6mercaptonicotinamide can avoid overhydration and loss of adhesiveness, resulting in a prolonged mucoadhesion [30,87]. Overall, chitosan-coated liposomes were proved to enhance the mucoadhesive property of several bioactive molecules when compared to conventional liposomes (Table 9). 


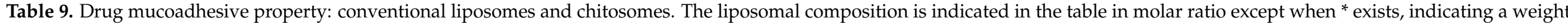
ratio $(w / w)$.

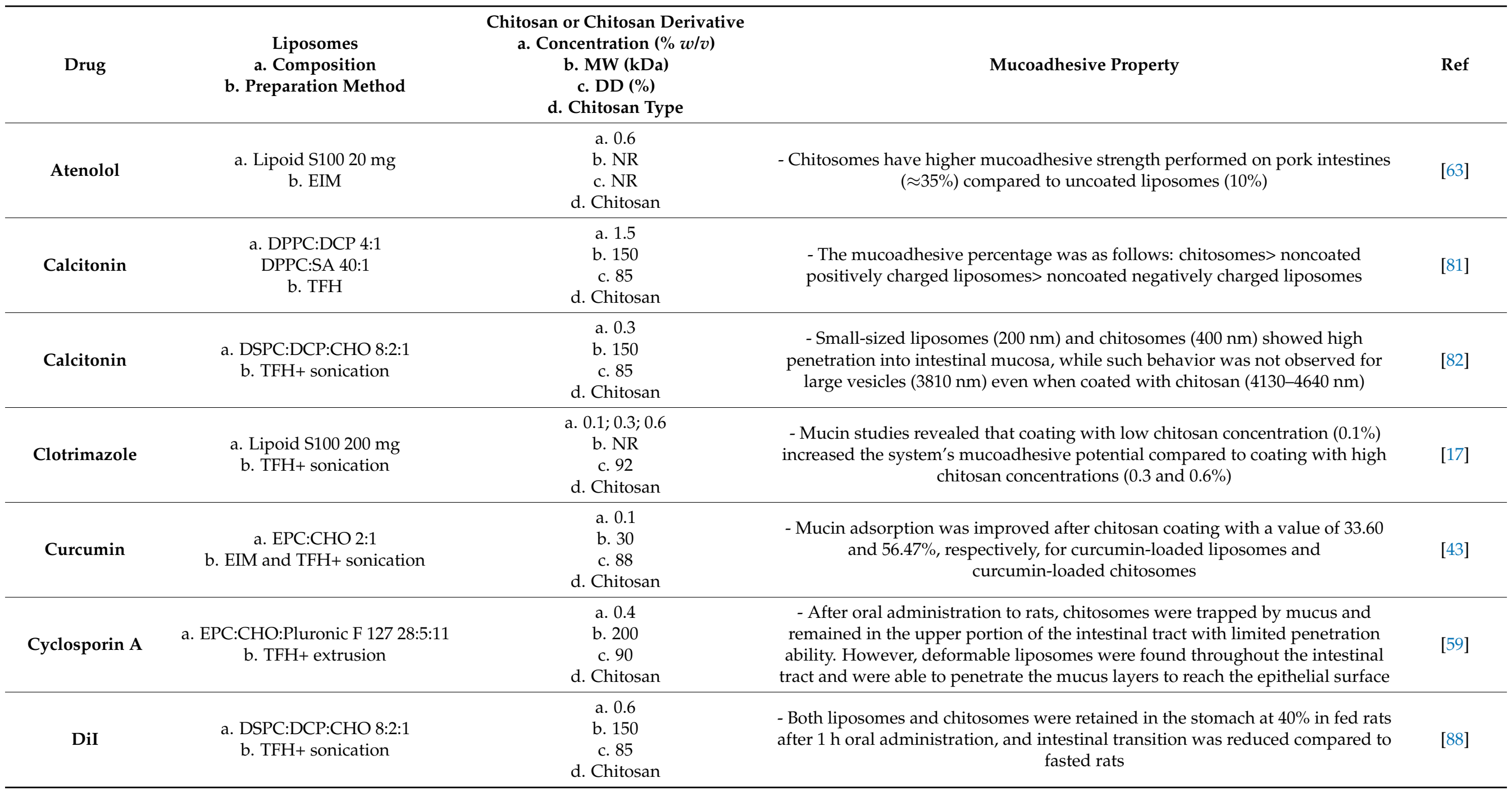


Table 9. Cont.

\begin{tabular}{|c|c|c|c|c|}
\hline Drug & $\begin{array}{c}\text { Liposomes } \\
\text { a. Composition } \\
\text { b. Preparation Method }\end{array}$ & $\begin{array}{c}\text { Chitosan or Chitosan Derivative } \\
\text { a. Concentration }(\% \text { w/v) } \\
\text { b. MW (kDa) } \\
\text { c. DD (\%) } \\
\text { d. Chitosan Type }\end{array}$ & Mucoadhesive Property & Ref \\
\hline Fexofenadine & $\begin{array}{l}\text { a. DPPC:DPPG:CHO 8:1:2.25 } \\
\text { b. TFH+ extrusion }\end{array}$ & $\begin{array}{c}\text { a. } 0.1 \\
\text { b. NR } \\
\text { c. NR } \\
\text { d. Chitosan }\end{array}$ & $\begin{array}{l}\text { - Mucoadhesive property was improved after chitosan coating with } 30 \text { and } 90 \% \\
\text { for fexofenadine-loaded liposomes chitosomes, respectively }\end{array}$ & [73] \\
\hline Rifampicin & $\begin{array}{c}\text { a. EPC:CHO 2:1 } \\
\text { EPC:PG:CHO 9:1:5 } \\
\text { DSPC:CHO 2:1 } \\
\text { DSPC:PG:CHO 9:1:5 } \\
\text { b. TFH+ sonication }\end{array}$ & $\begin{array}{l}\text { a. } 0.001-0.66 \\
\text { b. NR } \\
\text { c. } 87 \\
\text { d. Chitosan }\end{array}$ & $\begin{array}{l}\text { - The mucoadhesive percentage was in the following order: chitosomes> } \\
\text { noncoated uncharged liposomes }>\text { noncoated negatively charged liposomes }\end{array}$ & [32] \\
\hline Triazavirin & $\begin{array}{l}\text { a. SPC:CHO } 85: 15^{*} \\
\text { b. TFH+ extrusion }\end{array}$ & $\begin{array}{c}\text { a. } 0.275 \\
\text { b. } 190 \\
\text { c. } 95 \\
\text { d. Pelargonic chitosan; lauric } \\
\text { chitosan }\end{array}$ & $\begin{array}{l}\text { - Unmodified chitosomes showed } 1.3 \text { and } 1.6 \text { times higher mucoadhesive } \\
\text { properties than pelargonic- and lauric chitosan-coated liposomes, respectively }\end{array}$ & [29] \\
\hline
\end{tabular}




\subsubsection{Permeability and Drug Penetration Effect}

Chitosomes exhibited higher permeability and drug penetration into the skin than liposomes (Table 10). The increased skin drug permeation with chitosan coating could be explained by the tendency of positively charged chitosan to electrostatically interact with the negatively charged lipid present in the lipid layer of the stratum corneum to open the epidermal tight junctions and to promote the drug delivery [42,48]. In addition, chitosomes exhibited potential ocular applications by increasing transcorneal drug penetration, compared to uncoated liposomes or commercially available eye drops with no ocular irritation $[12,37,79]$. The penetration enhancing effect of chitosomes into the cornea was higher with HMW of chitosan [28] but did not increase with the excess amount of chitosan [12]. The main findings concerning the permeation enhancing effect of chitosomes in comparison to liposomes are shown in Table 10.

Table 10. Permeability and drug penetration studies: conventional liposomes and chitosomes. The liposomal composition is indicated in the table in molar ratio except when * exists, indicating a weight ratio $(w / w)$.

\begin{tabular}{|c|c|c|c|c|}
\hline Drug & $\begin{array}{l}\text { Liposomes } \\
\text { a. Composition } \\
\text { b. Preparation Method }\end{array}$ & $\begin{array}{l}\text { Chitosan or Chitosan } \\
\text { Derivative } \\
\text { a. Concentration }(\% \text { w/v) } \\
\text { b. MW (kDa) } \\
\text { c. DD (\%) } \\
\text { d. Chitosan Type }\end{array}$ & $\begin{array}{c}\text { Permeability and drug Penetration } \\
\text { Effect }\end{array}$ & Ref \\
\hline $\begin{array}{l}\text { Anti-sense } \\
\text { oligodeoxynu- } \\
\text { cleotides }\end{array}$ & $\begin{array}{l}\text { a. SPC:CHO } 20: 5^{*} \\
\text { b. TFH+ sonication }\end{array}$ & $\begin{array}{l}\text { a. } 0.05-1 \\
\text { b. } 100 \\
\text { c. } 90 \\
\text { d. Chitosan }\end{array}$ & $\begin{array}{c}\text { - Chitosomes significantly enhanced COS7 } \\
\text { cells uptake of anti-sense } \\
\text { oligodeoxynucleotides compared to the } \\
\text { nucleotide alone or } \\
\text { nucleotide-loaded liposomes }\end{array}$ & [53] \\
\hline BSA & $\begin{array}{l}\text { a. EPC:sodium oleate } \\
\text { 10:2 } \\
\text { b. TFH+ sonication }\end{array}$ & $\begin{array}{c}\text { a. } 20 \mathrm{mM} \\
\text { b. } 276 \\
\text { c. } 94 \\
\text { d. TMBz-chitosan }\end{array}$ & $\begin{array}{c}\text { - Compared to BSA-loaded liposomes, } \\
\text { TMBz chitosan-coated liposomes } \\
\text { enhanced BSA permeability across Caco-2 } \\
\text { cell monolayers }\end{array}$ & [25] \\
\hline Calcein & $\begin{array}{c}\text { a. PC:CHO 3:1 * } \\
\text { PC:Folate:PEG:CHO } \\
\text { 1:1:1:1 } \\
\text { b. TFH+ sonication }\end{array}$ & $\begin{array}{c}\text { a. } 0.5 \\
\text { b. } 50 \\
\text { c. NR } \\
\text { d. Octadecyl-quaternized } \\
\text { lysine modified chitosan }\end{array}$ & $\begin{array}{l}\text { - Octadecyl-quaternized lysine-modified } \\
\text { chitosan-coated deformable liposomes } \\
\text { showed higher calcein delivery to MCF-7 } \\
\text { cells compared to traditional liposomes }\end{array}$ & [22] \\
\hline Calcitonin & $\begin{array}{c}\text { a. DPPC:DPPE-MCC } \\
\text { 3:s0.3 } \\
\text { b. TFH+ extrusion }\end{array}$ & $\begin{array}{c}\text { a. } 0.2 \\
\text { b. } 150 \\
\text { c. NR } \\
\text { d. TGA chitosan; } \\
\text { TGA-MNA-chitosan }\end{array}$ & $\begin{array}{l}\text { - Calcitonin permeation enhancing effect } \\
\text { through intestinal mucus was more } \\
\text { pronounced for modified chitosomes than } \\
\text { uncoated liposomes with 1.8-, } 2.7-\text { and a } \\
\text { 3.8-fold increase for uncoated liposomes, } \\
\text { TGA chitosan-coated liposomes and } \\
\text { TGA-MNA-chitosan-coated liposomes, } \\
\text { respectively, compared to a calcitonin } \\
\text { buffer solution }\end{array}$ & [30] \\
\hline $\begin{array}{l}\text { Ciprofloxacin } \\
\text { hydrochlo- } \\
\text { ride }\end{array}$ & $\begin{array}{l}\text { a. PC:SA 10:0.5 } \\
\text { PC:DCP 10:1 } \\
\text { b. TFH }\end{array}$ & $\begin{array}{l}\text { a. } 0.3 \\
\text { b. } N R \\
\text { c. } 85 \\
\text { d. Chitosan }\end{array}$ & $\begin{array}{l}\text { - Chitosomes exhibited high drug levels in } \\
\text { the external eye of albino rabbits } \\
\text { compared to uncoated liposomes and the } \\
\text { commercially available eye drop, with no } \\
\text { ocular irritation }\end{array}$ & [37] \\
\hline $\begin{array}{l}\text { Coenzyme } \\
\text { Q10 }\end{array}$ & $\begin{array}{l}\text { a. SPC:CHO } 83: 17 * \\
\text { b. EIM+ sonication }\end{array}$ & $\begin{array}{c}\text { a. } 0.5 \\
\text { b. } 100 ; 450 \\
\text { c. }>85 \\
\text { d. Trimethyl chitosan }\end{array}$ & $\begin{array}{c}\text { - Trimethyl chitosan with HMW (450 kDa) } \\
\text { led to higher precorneal retention times } \\
\text { than that of LMW (100 kDa) and } \\
\text { liposomes }\end{array}$ & [28] \\
\hline $\begin{array}{c}\text { Cyclosporin } \\
\text { A }\end{array}$ & $\begin{array}{l}\text { a. HSPC:PS:CHO } \\
\text { 4:0.1:1 } \\
\text { b. EIM }\end{array}$ & $\begin{array}{l}\text { a. } 0.25 \\
\text { b. } 540 \\
\text { c. } 94 \\
\text { d. Chitosan }\end{array}$ & $\begin{array}{l}\text { - After topical instillation in rabbits, } \\
\text { cyclosporin A concentrations in cornea, } \\
\text { conjunctiva and sclera were higher in } \\
\text { chitosomes than in liposomes }\end{array}$ & [79] \\
\hline
\end{tabular}


Table 10. Cont.

\begin{tabular}{|c|c|c|c|c|}
\hline Drug & $\begin{array}{l}\text { Liposomes } \\
\text { a. Composition } \\
\text { b. Preparation Method }\end{array}$ & $\begin{array}{l}\text { Chitosan or Chitosan } \\
\text { Derivative } \\
\text { a. Concentration }(\% w / v) \\
\text { b. MW (kDa) } \\
\text { c. DD (\%) } \\
\text { d. Chitosan Type }\end{array}$ & $\begin{array}{l}\text { Permeability and drug Penetration } \\
\text { Effect }\end{array}$ & Ref \\
\hline $\begin{array}{l}\text { Diclofenac } \\
\text { sodium }\end{array}$ & $\begin{array}{l}\text { a. HSPC:PS:CHO } \\
\text { 3:0.1:1 } \\
\text { b. EIM }\end{array}$ & $\begin{array}{l}\text { a. } 0.25 ; 0.5 \\
\text { b. } 540 \\
\quad \text { c. } 97 \\
\text { d. Chitosan }\end{array}$ & $\begin{array}{l}\text { - Diclofenac sodium-loaded chitosomes } \\
\text { improved the transcorneal drug } \\
\text { penetration rate compared to uncoated } \\
\text { liposomes or commercially available eye } \\
\text { drops with no ocular irritation }\end{array}$ & [12] \\
\hline Flurbiprofen & $\begin{array}{l}\text { a. EPC:solutol HS15 } \\
\text { 7.5:1 } \\
\text { b. Modified EIM }\end{array}$ & $\begin{array}{l}\text { a. } 0.1 \\
\text { b. } 50 \\
\text { c. } 95 \\
\text { d. Chitosan }\end{array}$ & $\begin{array}{c}\text { - The apparent permeability coefficient of } \\
\text { flurbiprofen-loaded deformable } \\
\text { chitosomes evaluated using isolated } \\
\text { rabbit corneas was } 1.29 \text {-fold greater than } \\
\text { that of uncoated flurbiprofen-loaded } \\
\text { deformable liposomes }\end{array}$ & [61] \\
\hline Furosemide & $\begin{array}{l}\text { a. SPC:CHO 10:1 } \\
\text { b. TFH+ sonication }\end{array}$ & $\begin{array}{l}\text { a. } 0.5 \\
\text { b. NR } \\
\text { c. NR } \\
\text { d. Chitosan }\end{array}$ & $\begin{array}{l}\text { - Chitosomes increased the apical to } \\
\text { basolateral permeability of furosemide by } \\
\text { 8-fold through Caco- } 2 \text { cells compared to } \\
\text { furosemide loaded liposomes and } \\
\text { furosemide solution }\end{array}$ & {$[4]$} \\
\hline Lidocaine & $\begin{array}{l}\text { a. Lecithin:SDC } 15 \% \text { * } \\
\text { b. TFH+ sonication+ } \\
\text { extrusion }\end{array}$ & $\begin{array}{l}\text { a. } 0.3 \\
\text { b. } 150 \\
\text { c. } 90 \\
\text { d. Chitosan }\end{array}$ & $\begin{array}{l}\text { - Chitosan-coated elastic liposomes } \\
\text { significantly improved lidocaine } \\
\text { hydrochloride skin permeation compared } \\
\text { to elastic liposome and chitosan solution }\end{array}$ & [48] \\
\hline Resveratrol & $\begin{array}{c}\text { a. EPC } 2 \% \text { * } \\
\text { b. TFH+ sonication }\end{array}$ & $\begin{array}{l}\text { a. } 0.1 \\
\text { b. NR } \\
\text { c. NR } \\
\text { d. Chitosan }\end{array}$ & $\begin{array}{c}\text {-Resveratrol permeated skin animal with } \\
40.42 \text { and } 30.84 \% \text { for chitosomes and } \\
\text { liposomes, respectively }\end{array}$ & [42] \\
\hline
\end{tabular}

\subsubsection{Cytotoxicity}

Chitosomes proved a high cell attraction which potentially increased the cellular drug uptake leading to drug cytotoxicity as demonstrated by MTT assay [55]. Table 11 reported an enhanced cytotoxic effect on several cancer cell lines for various drug-loaded chitosomes or -modified chitosomes when compared to drug-conventional liposomes and free drugs. It is important to note that the cell viability decreased with increasing chitosan concentration [79]. In addition, the $\mathrm{pH}$ affects the surface charge of glycol chitosomes leading to an improvement in their antitumor efficacy compared to uncoated liposomes (Table 11) [23].

\subsubsection{Other Biological Effects}

The coating of the liposomes with chitosan and its derivatives confers not only high mucoadhesion capacity, antimicrobial activity and enhanced carrier permeability but also enhanced other biological activities, including anti-inflammatory, immune-stimulatory effect, analgesic and suppression of gene expression as reported in Table 12. 
Table 11. Cytotoxicity and anticancer effect of drugs: conventional liposomes and chitosomes. The liposomal composition is indicated in the table in molar ratio except when * exists, indicating a weight ratio $(w / w)$.

\begin{tabular}{|c|c|c|c|c|}
\hline Drug & $\begin{array}{l}\text { Liposomes } \\
\text { a. Composition } \\
\text { b. Preparation Method }\end{array}$ & $\begin{array}{l}\text { Chitosan or Chitosan } \\
\text { Derivative } \\
\text { a. Concentration (\% w/v) } \\
\text { b. MW (kDa) } \\
\text { c. DD (\%) } \\
\text { d. Chitosan Type }\end{array}$ & $\begin{array}{c}\text { Cytotoxicity and Anticancer Effects of } \\
\text { Drugs }\end{array}$ & Ref \\
\hline Butyric acid & $\begin{array}{l}\text { a. PC:CHO 20:5* } \\
\text { b. TFH+ sonication }\end{array}$ & $\begin{array}{l}\text { a. } 0.1 \\
\text { b. NR } \\
\text { c. NR } \\
\text { d. Chitosan }\end{array}$ & $\begin{array}{l}\text { - Chitosomes displayed higher } \\
\text { cytotoxicity against human } \\
\text { hepatoblastoma HepG2 cells with an IC50 } \\
\text { value of } 1.6 \mathrm{mM} \text { after } 72 \mathrm{~h} \text { of incubation } \\
\text { than uncoated liposomes }(2.7 \mathrm{mM}) \text { and } \\
\text { free butyric acid }(4.5 \mathrm{mM})\end{array}$ & [72] \\
\hline $\begin{array}{c}\text { Cyclosporin } \\
\text { A }\end{array}$ & $\begin{array}{l}\text { a. HSPC:PS:CHO } \\
\text { 4:0.1:1 } \\
\text { b. EIM }\end{array}$ & $\begin{array}{l}\text { a. } 0.25 ; 0.5 ; 1 ; 2 \\
\text { b. } 540 \\
\text { c. } 94 \\
\text { d. Chitosan }\end{array}$ & $\begin{array}{l}\text { - Chitosomes and liposomes loading } \\
\text { cyclosporin A demonstrated low toxicity } \\
\text { to rabbit conjunctival epithelium cells }\end{array}$ & [79] \\
\hline Docetaxel & $\begin{array}{l}\text { a. Lipoid S100:CHO: } \\
\text { Tween-80:SDC:DCP } \\
\text { 0.9:0.3:0.1:0.1:0.1 } \\
\text { b. TFH+ sonication }\end{array}$ & $\begin{array}{l}\text { a. } 1 \\
\text { b. NR } \\
\text { c. NR } \\
\text { d. Chitosan }\end{array}$ & $\begin{array}{l}\text { - Uncoated deformable liposomes } \\
\text { displayed } 52 \% \text { of human colon cancer } \\
\text { HT-29 cell growth, and cell viability was } \\
\text { greatly reduced by } 80 \% \text { in deformable } \\
\text { chitosomes, indicating enhanced cytotoxic } \\
\text { activity for deformable chitosomes }\end{array}$ & [55] \\
\hline Doxorubicin & $\begin{array}{l}\text { a. HSPC:CHO NR } \\
\text { b. TFH+ extrusion }\end{array}$ & $\begin{array}{c}\text { a. NR } \\
\text { b. NR } \\
\text { c. NR } \\
\text { d. Glycol chitosan }\end{array}$ & $\begin{array}{l}\text { - Glycol chitosan-coated } \\
\text { doxorubicin-loaded liposomes resulted in } \\
\text { a } 64 \% \text { reduction in HT1080 cells viability } \\
\text { at pH } 6.5 \text { and less than } 15 \% \text { reduction at } \\
\text { pH } 7.4 \text { compared to uncoated liposomes } \\
\text { exhibiting less than } 20 \% \text { reduction in } \\
\text { viability regardless of pH }\end{array}$ & [23] \\
\hline Doxorubicin & $\begin{array}{l}\text { a. HSPC:CHO NR } \\
\text { b. TFH+ extrusion }\end{array}$ & $\begin{array}{c}\text { a. NR } \\
\text { b. NR } \\
\text { c. NR } \\
\text { d. Glycol chitosan }\end{array}$ & $\begin{array}{l}\text { - Hematoxylin and eosin-stained tumor } \\
\text { sections excised from tumor-bearing mice } \\
\text { following intravenous injection of free } \\
\text { doxorubicin and doxorubicin-loaded } \\
\text { liposomes and glycol chitosan-coated } \\
\text { doxorubicin-loaded liposomes showed } \\
\text { the strongest antitumor effect for glycol } \\
\text { chitosan-coated doxorubicin-loaded } \\
\text { liposomes }\end{array}$ & [23] \\
\hline
\end{tabular}

\begin{tabular}{|c|c|c|c|c|}
\hline Furosemide & $\begin{array}{l}\text { a. SPC:CHO 10:1 } \\
\text { b. TFH+ sonication }\end{array}$ & $\begin{array}{l}\text { a. } 0.5 \\
\text { b. NR } \\
\text { c. NR } \\
\text { d. Chitosan }\end{array}$ & $\begin{array}{l}\text { - Chitosomes showed less cytotoxicity } \\
\text { toward Caco-2 cells than uncoated ones }\end{array}$ & [4] \\
\hline Paclitaxel & $\begin{array}{l}\text { a. Lecithin:CHO:SA } \\
\text { 1.225:0.575:0.1 } \\
\text { b. TFH+ sonication }\end{array}$ & $\begin{array}{l}\text { a. } 0.1 \\
\text { b. } 50 \\
\text { c. } N R \\
\text { d. Chitosan }\end{array}$ & $\begin{array}{l}\text { - Chitosomes enhanced paclitaxel-induced } \\
\text { cytotoxicity in human cervical cancer cells } \\
\text { compared to paclitaxel loaded-liposomes }\end{array}$ & [74] \\
\hline Rifampicin & $\begin{array}{c}\text { a. EPC:CHO 2:1 } \\
\text { EPC:PG:CHO 9:1:5 } \\
\text { DSPC:CHO 2:1 } \\
\text { DSPC:PG:CHO 9:1:5 } \\
\text { b. TFH+ sonication }\end{array}$ & $\begin{array}{l}\text { a. } 0.001-0.66 \\
\text { b. NR } \\
\text { c. } 87 \\
\text { d. Chitosan }\end{array}$ & $\begin{array}{l}\text {-The toxicity of rifampicin-loaded } \\
\text { liposomes towards A549 epithelial cells } \\
\text { was lower compared to the free drug for } \\
\text { all the vesicles types (negatively charged } \\
\text { and non-charged ones), especially } \\
\text { chitosan-coated ones }\end{array}$ & [32] \\
\hline $\begin{array}{l}\text { si } \\
\text { RNA-VEGF } \\
\text { si } \\
\text { RNA-H1F1- } \alpha\end{array}$ & $\begin{array}{l}\text { a. HSPC:CHO 1:1 } \\
\text { HSPC:DCP:CHO1:0.1:1 } \\
\text { HSPC:SA:CHO1:0.1:1 } \\
\text { b. TFH+ sonication }\end{array}$ & $\begin{array}{l}\text { a. } 1 \\
\text { b. } 75 \\
\text { c. } 75-85 \\
\text { d. Chitosan }\end{array}$ & $\begin{array}{l}\text { - Chitosomes showed } 96 \% \text { of MCF7 cancer } \\
\text { cell viability. However, anionic and } \\
\text { cationic liposomes showed reduced cell } \\
\text { viability of } 76.27 \text { and } 67.79 \% \text {, respectively }\end{array}$ & [75] \\
\hline
\end{tabular}


Table 11. Cont.

\begin{tabular}{|c|c|c|c|c|}
\hline Drug & $\begin{array}{l}\text { Liposomes } \\
\text { a. Composition } \\
\text { b. Preparation Method }\end{array}$ & $\begin{array}{l}\text { Chitosan or Chitosan } \\
\text { Derivative } \\
\text { a. Concentration }(\% w / v) \\
\text { b. MW (kDa) } \\
\text { c. DD (\%) } \\
\text { d. Chitosan Type }\end{array}$ & $\begin{array}{c}\text { Cytotoxicity and Anticancer Effects of } \\
\text { Drugs }\end{array}$ & Ref \\
\hline Substance $\mathbf{P}$ & $\begin{array}{l}\text { a. Lecithin:CHO 20:3.3* } \\
\text { b. TFH+ sonication }\end{array}$ & $\begin{array}{l}\text { a. } 0.1 \\
\text { b. } \mathrm{NR} \\
\text { c. } 88 \\
\text { d. Chitosan }\end{array}$ & $\begin{array}{l}\text {-Both chitosomes and liposomes loading } \\
\text { substance P showed no toxic effect on } \\
\text { keratinocytes at different tested } \\
\text { concentrations }\end{array}$ & [34] \\
\hline
\end{tabular}

Table 12. Other biological effects of drugs: conventional liposomes and chitosomes. The liposomal composition is indicated in the table in molar ratio except when * exists, indicating a weight ratio $(w / w)$.

\begin{tabular}{|c|c|c|c|c|}
\hline Drug & $\begin{array}{c}\text { Liposomes } \\
\text { a. Composition } \\
\text { b. Preparation Method }\end{array}$ & $\begin{array}{l}\text { Chitosan or Chitosan } \\
\text { Derivative } \\
\text { a. Concentration (\% w/v) } \\
\text { b. MW (kDa) } \\
\text { c. DD (\%) } \\
\text { d. Chitosan Type }\end{array}$ & Other Biological Effects & Ref \\
\hline Butyric acid & $\begin{array}{l}\text { a. PC:CHO 20:5* } \\
\text { b. TFH+ sonication }\end{array}$ & $\begin{array}{c}\text { a. } 0.1 \\
\text { b. NR } \\
\text { c. NR } \\
\text { d. Chitosan }\end{array}$ & $\begin{array}{l}\text { - Chitosomes showed higher } \\
\text { anti-inflammatory effects by } \\
\text { reducing IL-8, IL- } 6, \text { TNF- } \alpha \text { and } \\
\text { TGF- } \beta \text { expression in HepG2 cells } \\
\text { compared to free butyric acid } \\
\text { and butyric acid-loaded } \\
\text { liposomes at different tested } \\
\text { concentrations }\end{array}$ & [72] \\
\hline $\begin{array}{l}\text { Extracellular } \\
\text { proteins }\end{array}$ & $\begin{array}{l}\text { a. Lecithin } 100 \mathrm{mg} \\
\text { b. EIM }\end{array}$ & $\begin{array}{c}\text { a. } 0.3 \\
\text { b. NR } \\
\text { c. NR } \\
\text { d. Chitosan }\end{array}$ & $\begin{array}{l}\text { Nonspecific immune parameters } \\
\text { myeloperoxidase, respiratory } \\
\text { burst, hemagglutination, } \\
\text { hemolytic, antiprotease activity } \\
\text { and bacterial agglutination } \\
\text { activity were tested after } \\
\text { parenteral immunization in fish } \\
\text { and rabbits. The specific } \\
\text { antibody level was also } \\
\text { measured. Chitosomes showed } \\
\text { significantly higher specific and } \\
\text { nonspecific immune responses } \\
\text { than the liposomes }\end{array}$ & [57] \\
\hline Lidocaine & $\begin{array}{l}\text { a. Lecithin:SDC } 15 \% \text { * } \\
\text { b. TFH+ sonication+ } \\
\text { extrusion }\end{array}$ & $\begin{array}{c}\text { a. } 0.3 \\
\text { b. } 150 \\
\text { c. } 90 \\
\text { d. Chitosan }\end{array}$ & $\begin{array}{l}\text { - Chitosan-coated elastic } \\
\text { lidocaine loaded liposomes } \\
\text { revealed greater suppression of } \\
\text { formalin-induced nociceptive } \\
\text { behavior in mice transdermally } \\
\text { treated, thus a better analgesic } \\
\text { effect compared to elastic } \\
\text { liposome and chitosan solution }\end{array}$ & [48] \\
\hline
\end{tabular}


Table 12. Cont.

\begin{tabular}{|c|c|c|c|c|}
\hline Drug & $\begin{array}{c}\text { Liposomes } \\
\text { a. Composition } \\
\text { b. Preparation Method }\end{array}$ & $\begin{array}{l}\text { Chitosan or Chitosan } \\
\text { Derivative } \\
\text { a. Concentration }(\% \text { w/v) } \\
\text { b. MW (kDa) } \\
\text { c. DD (\%) } \\
\text { d. Chitosan Type }\end{array}$ & Other Biological Effects & Ref \\
\hline $\begin{array}{l}\text { si RNA-VEGF } \\
\text { si RNA-H1F1- } \alpha\end{array}$ & $\begin{array}{c}\text { a. HSPC:CHO 1:1 } \\
\text { HSPC:DCP:CHO 1:0.1:1 } \\
\text { HSPC:SA:CHO 1:0.1:1 } \\
\text { b. TFH+ sonication }\end{array}$ & $\begin{array}{c}\text { a. } 1 \\
\text { b. } 75 \\
\text { c. } 75-85 \\
\text { d. } \text { Chitosan }\end{array}$ & $\begin{array}{l}\text { - VEGF and HIF1- } \alpha \text { protein } \\
\text { levels in cells treated with } \\
\text { anionic liposomes were } \\
\text { significantly lower than those } \\
\text { treated with cationic and } \\
\text { chitosan-coated ones. } \\
\text { - In vitro codelivery of siVEGF } \\
\text { and siHIF1- } \alpha \text { in breast cancer } \\
\text { cells using chitosomes } \\
\text { significantly inhibited VEGF } \\
(89 \%) \text { and HIF1- } \alpha(62 \%) \text { protein } \\
\text { expression compared to other } \\
\text { liposome formulations. }\end{array}$ & [75] \\
\hline
\end{tabular}

\section{Multilayer Coating of Polyelectrolytes on the Liposomes}

A few studies have developed a polyelectrolyte delivery system (PDS) based on liposomes coated with alternating layers of polysaccharides, such as chitosan, alginate, hyaluronate or pectin $[64,78,80,89,90]$. PDS is represented in Figure 5, in which positively charged chitosan was self-assembly coated onto the anionic liposome surface, and negatively charged alginate, hyaluronate or pectin was then deposited on the outer layer of cationic liposomes.

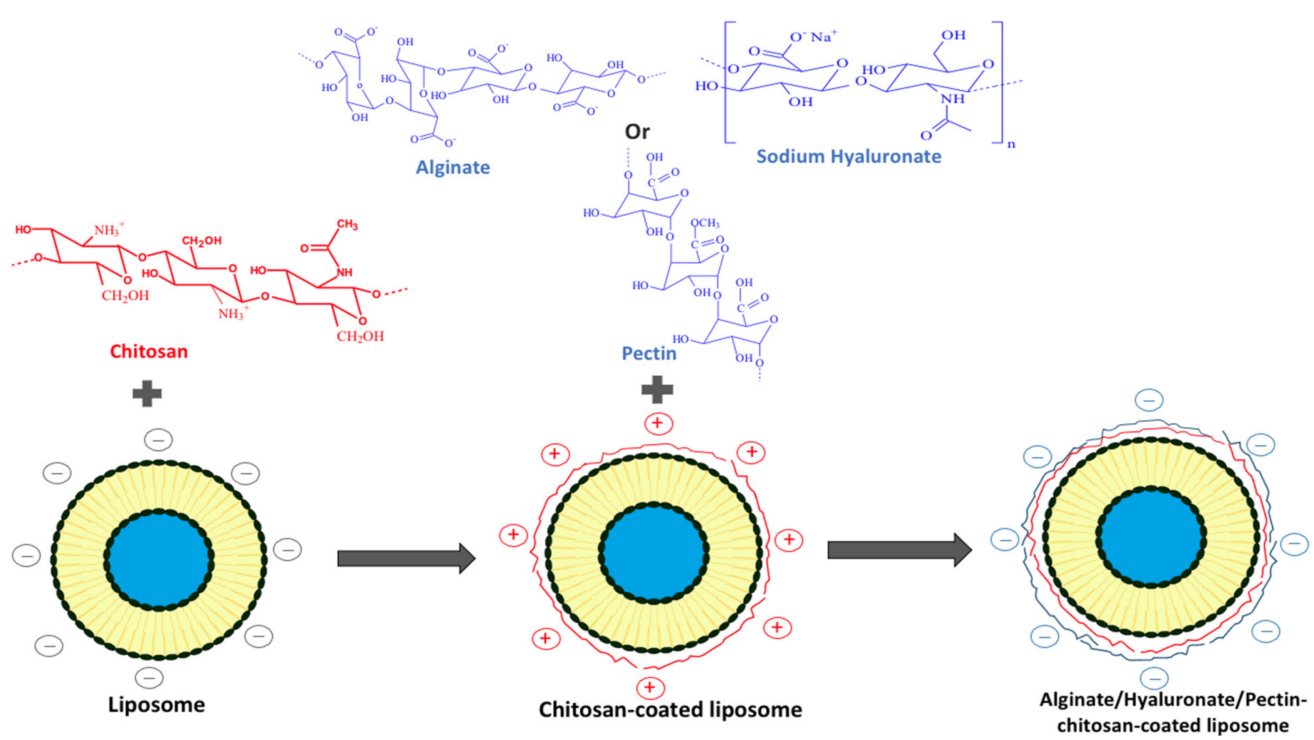

Figure 5. Preparation of polyelectrolyte delivery system layer-by-layer self-assembly of chitosan and alginate/hyaluronate/pectin onto the liposome.

The effect of alternating layers of cationic and anionic polysaccharides on the liposome surface is presented in this section. The characteristics of PDS in comparison to chitosomes and conventional liposomes are presented in Table 13. The adsorbed polymers on the liposomal surface caused a negative zeta potential, an increase in the membrane thickness $[89,90]$, in size $[64,78,80,89,90]$, and in drug EE, which increased with increasing layers of polyelectrolytes [89]. 


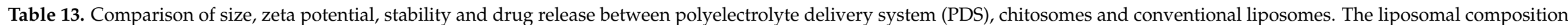
is indicated in the table in molar ratio except when * exists, indicating a weight ratio $(w / w)$.

\begin{tabular}{|c|c|c|c|c|c|c|}
\hline $\begin{array}{l}\text { Liposome } \\
\text { a. Composition } \\
\text { b. Preparation Method } \\
\text { c. Drug/EO }\end{array}$ & $\begin{array}{l}\text { Chitosan } \\
\text { a. Concentration }(\% \\
w / v) \\
\text { b. MW (kDa) } \\
\text { c. DD (\%) }\end{array}$ & $\begin{array}{l}\text { a. Anionic } \\
\text { Polysaccharide } \\
\text { b. Concentration }(\% \\
w / v) \\
\text { c. MW (kDa) }\end{array}$ & $\begin{array}{l}\text { Size }(\mathrm{nm}) \\
\text { a. PDS } \\
\text { b. CH-LP } \\
\text { c. UN-LP }\end{array}$ & $\begin{array}{l}\text { Zeta Potential (mv) } \\
\text { a. PDS } \\
\text { b. CH-LP } \\
\text { c. UN-LP }\end{array}$ & Drug Release & Ref \\
\hline $\begin{array}{c}\text { a. DPPC:CHO: DDAB } \\
\text { NR } \\
\text { b. TFH+ extrusion } \\
\text { c. BSA }\end{array}$ & $\begin{array}{l}\text { a. } 0.1 \\
\text { b. } 91.11 \\
\text { c. } 85\end{array}$ & $\begin{array}{l}\text { a. Alginate } \\
\text { b. } 0.1 \\
\text { c. } 12\end{array}$ & $\begin{array}{l}\text { a. } 345 \pm 10.9 \\
\quad \text { b. NR } \\
\text { c. } 180 \pm 10.5\end{array}$ & $\begin{array}{l}\text { a. } 36.6 \\
\text { b. NR } \\
\text { c. } 35.4\end{array}$ & $\begin{array}{l}\text { - BSA released from uncoated liposomes is } \\
\text { faster than from PDS } \\
\text { - The increase in coating thickness by } \\
\text { increasing polyelectrolyte layers number } \\
\text { decreased protein release rate }\end{array}$ & [89] \\
\hline $\begin{array}{l}\text { a. Lecithin:CHO 5:1 } \\
\text { b. TFH+extrusion } \\
\text { c. Chrysanthemum sp. }\end{array}$ & $\begin{array}{l}\text { a. } 0.0025-0.01 \\
\text { b. NR } \\
\text { c. NR }\end{array}$ & $\begin{array}{l}\text { a. Pectin } \\
\text { b. } 0.0025-0.01 \\
\text { c. NR }\end{array}$ & $\begin{array}{l}\text { a. } 642 \pm 7-3235 \pm 7 \\
\text { b. } 530 \pm 5-793 \pm 7.5 \\
\text { c. } 98 \pm 6-231 \pm 9\end{array}$ & $\begin{array}{l}\text { a. }-19.3--13.5 \\
\text { b. } 34.2-45.4 \\
\text { c. }-37.6--27.7\end{array}$ & $\begin{array}{c}\text { - PDS strongly reduced the leakage of EO } \\
\text { from the liposomes } \\
\text { - Liposomes exhibited the highest release } \\
\text { rate }(88.2 \%) \text {, followed by chitosomes } \\
(60.2 \%), \text { and lastly, by triple layer } \\
\text { liposomes }(25.2 \%)\end{array}$ & {$[78]$} \\
\hline $\begin{array}{l}\text { a. Lipoid S75 1, 2, 5\% * } \\
\text { b. High shear disperser + } \\
\text { microfluidization } \\
\text { c. Hibiscus extract }\end{array}$ & $\begin{array}{l}\text { a. } 1 \\
\text { b. NR } \\
\text { c. } 79\end{array}$ & $\begin{array}{l}\text { a. Pectin } \\
\text { b. } 0.005-0.1 \\
\text { c. } 55\end{array}$ & $\begin{array}{l}\text { a. } 98-343 \\
\text { b. } 60-150 \\
\text { c. } 32-46\end{array}$ & $\begin{array}{l}\text { a. }-25 \\
\text { b. } 78 \\
\text { c. }-29\end{array}$ & NR & {$[91]$} \\
\hline $\begin{array}{l}\text { a. SPC:CHO: } \\
\text { Tween-80:6:1:1.8* } \\
\text { b. TFH+ high-pressure } \\
\text { microfluidization } \\
\text { c. Medium-chain fatty } \\
\text { acids }\end{array}$ & $\begin{array}{l}\text { a. } 0.05-2 \\
\text { b. } 50 \\
\text { c. NR }\end{array}$ & $\begin{array}{l}\text { a. Alginate } \\
\text { b. } 0.1-2 \\
\text { c. } 12\end{array}$ & $\begin{array}{c}\text { a. } 170 \pm 28-3229 \pm 203 \\
\text { b. } 124 \pm 19-255 \pm 35 \\
\text { c. } 89\end{array}$ & $\begin{array}{l}\text { a. } 1.5--16.1 \\
\text { b. }-1.1-3.1 \\
\quad \text { c. }-6.3\end{array}$ & $\begin{array}{l}\text { - In SGF, all liposomes formulations } \\
\text { showed low medium-chain fatty acids } \\
\text { release rates ( } 29.8 \text { and } 20.4 \% \text { for the } \\
\text { liposomes and PDS, respectively) } \\
\text { - In SIF, liposomes exhibited the highest } \\
\text { medium-chain fatty acids }(79.8 \%) \text { release } \\
\text { rate compared to PDS }(56.9 \%)\end{array}$ & {$[90]$} \\
\hline $\begin{array}{l}\text { a. EPC:CHO: DHP } \\
\text { 10:2.5:1 } \\
\text { b. TFH+ sonication } \\
\text { c. Quercetin }\end{array}$ & $\begin{array}{l}\text { a. } 0.1 \\
\text { b. } 50-190 \\
\text { c. NR }\end{array}$ & $\begin{array}{c}\text { a. Sodium hyaluronate } \\
\text { b. } 0.1 \\
\text { c. } 490\end{array}$ & $\begin{array}{l}\text { a. } 528 \pm 29 \\
\text { b. NR } \\
\text { c. } 121 \pm 2.2\end{array}$ & $\begin{array}{l}\text { a. }-50 \\
\text { b. NR } \\
\text { c. }-38.2\end{array}$ & $\begin{array}{l}\text { - Uncoated liposomes exhibited the highest } \\
\text { quercetin released amount after } 24 \mathrm{~h}(62 \% \\
\text { at pH } 5.5 \text { and } 50 \% \text { at } \mathrm{pH} 7.4) \\
\text { - Quercetin exhibited a sustained release as } \\
\text { the number of polyelectrolyte layers } \\
\text { increased up to } 5 \text { (below } 20 \% \text { at both } \mathrm{pH})\end{array}$ & {$[80]$} \\
\hline
\end{tabular}


Table 13. Cont.

\begin{tabular}{|c|c|c|c|c|c|c|}
\hline $\begin{array}{l}\text { Liposome } \\
\text { a. Composition } \\
\text { b. Preparation Method } \\
\text { c. Drug/EO }\end{array}$ & $\begin{array}{c}\text { Chitosan } \\
\text { a. Concentration (\% } \\
w / v) \\
\text { b. MW (kDa) } \\
\text { c. DD }(\%)\end{array}$ & $\begin{array}{c}\text { a. Anionic } \\
\text { Polysaccharide } \\
\text { b. Concentration }(\% \\
w / v) \\
\text { c. MW (kDa) }\end{array}$ & $\begin{array}{l}\text { Size }(\mathrm{nm}) \\
\text { a. PDS } \\
\text { b. CH-LP } \\
\text { c. UN-LP }\end{array}$ & $\begin{array}{l}\text { Zeta Potential (mv) } \\
\text { a. PDS } \\
\text { b. CH-LP } \\
\text { c. UN-LP }\end{array}$ & Drug Release & Ref \\
\hline $\begin{array}{c}\text { a. SPC:CHO: Tween- } 80 \\
\text { 6:1:1.8* } \\
\text { b. TFH+ high-pressure } \\
\text { microfluidization } \\
\text { c. Vitamin C }\end{array}$ & $\begin{array}{l}\text { a. } 0.6 \\
\text { b. } 50 \\
\text { c. NR }\end{array}$ & $\begin{array}{l}\text { a. Alginate } \\
\text { b. } 0.5 \\
\text { c. } 12\end{array}$ & $\begin{array}{l}\text { a. } 1809 \pm 210 \\
\text { b. } 1098 \pm 46 \\
\text { c. } 601 \pm 76\end{array}$ & $\begin{array}{l}\text { a. }-25.2 \\
\text { b. } 24.5 \\
\text { c. }-12.5\end{array}$ & $\begin{array}{l}\text { In SGF, all liposome formulations showed } \\
\text { low vitamin C release rates }(25,27 \text { and } 14 \% \\
\text { for the liposomes, chitosomes and PDS, } \\
\text { respectively). In SIF, PDS exhibited the } \\
\text { slowest vitamin release rate }(10 \%) \\
\text { compared to chitosomes }(30 \%) \text { and } \\
\text { liposomes }(82 \%)\end{array}$ & [64] \\
\hline
\end{tabular}


It has been reported that the addition of polyelectrolyte layer improved liposomal stability. For example, triple-layer liposomes composed of chitosan and pectin-loading hibiscus extract were more stable than the liposomes after 30 days of storage at $25^{\circ} \mathrm{C}$ with the highest stability obtained with PDS [91]. In addition, triple-layer liposomes containing Chrysanthemum sp. exhibited better stability after 60 days at different temperatures $\left(4,12,25\right.$ and $\left.37^{\circ} \mathrm{C}\right)$ in terms of particle size, pdI and zeta potential than conventional liposomes and chitosomes [78]. Liposomes modified by chitosan and alginate were stable after 12 months at room temperature without significant changes in their size [89]. PDS systems were not only proved to be stable at aqueous suspensions but also in lyophilized forms. The lyophilization of PDS in the presence of sucrose maintained their size and zeta potential values as those before lyophilization [89].

It is important to note that medium composition ( $\mathrm{pH}$ and $\mathrm{NaCl}$ concentration) affected the PDS stability. PDS size increased significantly from $170 \mathrm{~nm}$ at $\mathrm{pH} 1.5$ to $410 \mathrm{~nm}$ at $\mathrm{pH} 5$ then decreased to $235 \mathrm{~nm}$ at $\mathrm{pH} 9$. However, uncoated liposomes maintained stable at different $\mathrm{pH}$. In SGF, both liposomes and PDS showed a slight change in size for $120 \mathrm{~min}$. In SIF (pH 7.4), compared to the liposomes (from 107 to $114 \mathrm{~nm}$ ), PDS size increased significantly from 335 to $620 \mathrm{~nm}$ over $15 \mathrm{~min}$ of digestion and decreased to $530 \mathrm{~nm}$ at the end of digestion [90]. In addition, high $\mathrm{NaCl}$ concentration $(200 \mathrm{mM})$ at pH 5.5 induced more alteration of PDS than chitosomes and uncoated liposomes in appearance and mean diameter, but the cores (liposomes) of these systems were maintained stable [64]. The following mechanism explained the PDS stability affected by the medium composition. At low $\mathrm{pH}$ conditions ( $\mathrm{pH}$ 1.5), outer-layer alginate shrank and converted into an insoluble so-called alginic acid skin which protected chitosan from dissolution. With $\mathrm{pH}$ value increase (even in SIF conditions), there was a decrease in the number of charged cationic groups on chitosan. Thus, the electrostatic interaction between the carboxyl group of alginate and the amino group of chitosan was weaker, medium gradually entered into the particles, and the mean diameter increased. The subsequent decrease in mean diameter could be due to some of the alginate being progressively dissolved. In addition, in SIF conditions, this decrease in the size was explained by the higher affinity of chitosan to bile salts ions than to the liposomes [90]. This was supported by the influence of ionic concentration in the medium on the PDS stability. At pH 5.5 and in the presence of low ionic $\mathrm{NaCl}$ concentration, the carboxyl group of alginate was ionized, and the amine group of chitosan was protonated. Interaction in the polyionic complex could govern the alginatechitosan-coated liposomes to swell water to fill the void regions of the polymer network between alginate and chitosan. When they encountered electrolyte solutions, such as high $\mathrm{NaCl}$ concentrations, the equilibrium state was provoked. Ions competed with polymers to interact with water, electrostatic interaction and steric force were weakened, resulting in the erosion of alginate-chitosan-coated liposomes and phase separation between water and particles [64].

In addition, the concentration of anionic polysaccharides affects the PDS stability, where both a higher and lower addition of pectin to chitosan-coated liposomes above or below the concentration of saturation resulted in the destabilization of the liposomes via bridging flocculation [91]. The temperature also affects the PDS stability. PDS size decreased after $1 \mathrm{~h}$ at $70{ }^{\circ} \mathrm{C}$ due to the degradation of the outer layer alginate at hightemperature. The following increase of particle size may be due to the increased propensity for inter-chain cross-linking of chitosan under the influence of heating [90]. Moreover, PDS composed of 2 polyelectrolytes layers were stable after 3 weeks at $25^{\circ} \mathrm{C}$, whereas a size increase and flocculation were obtained for those composed of 3 to 5 polyelectrolytes layers [80].

PDS delayed the release of encapsulated contents in SGF and SIF compared to chitosomes and conventional liposomes due to several possible mechanisms as follows: (a) there was a physical barrier (shrunken alginate network at low $\mathrm{pH}$ and insoluble chitosan layers at high $\mathrm{pH}$ ) formed on the liposome surface and then enzyme (pancreatic lipase, phospholipase A2, and cholesterol esterase) was restricted to contact with the liposomal 
phospholipids; (b) electrostatic bridges existing between the phospholipids and polymers reduced the lipid bilayer permeability [90]; (c) formation of a denser shell through the ionic interaction of the two polymers [80].

In vitro skin permeability studies showed that negatively charged sodium hyaluronatechitosan-coated liposomes and positively charged chitosomes have similar skin permeability, which was superior to uncoated liposomes. This was explained by the ability of hyaluronate to increase the stratum corneum hydration due to its water uptake properties [80].

\section{Encapsulation of Essential Oils: Chitosomes vs. Liposomes. Novel Formulation Strategies for Old Antimicrobials}

In the last decades, a growing interest in using plant-based antimicrobials has been known a rise, and special attention was given to EOs. EOs are products obtained from aromatic plants by physical processes of distillation or pressing [92]. They contain volatile compounds stored in plant's specialized structures to offer protection against various insults, including pathogen (bacteria, fungi, viruses) attacks [93]. EOs are complex mixtures of small lipophilic molecules, of which one up to three compounds constitute the main phytochemical markers; still, other minor compounds contribute by phyto-synergic interactions to the overall bioactivity of EOs [94,95].

Isolation of EOs from plant matrices is classically achieved by hydrodistillation (steam or water distillation), but other methods, such as cold and hot expression, microwave-, ultrasonic-solvent free and supercritical fluid extraction, are also employed [96,97].

Generally, EOs constituents are regarded as safe (GRAS) by the FDA, a status that permitted the use of EOs as flavoring agents in food and as additives to cosmetics, perfumes, and cleaning products [94]. In addition, the combination of orange essential oil and trehalose was found to have a great impact on barrier protection against UV-vis radiation. This synergistic effect is potentially useful in using these films as protectants for food packaging and improvers of shelf life and food quality [98]. More, EOs possess a broadspectrum of significant biological activities with applications in medical and pharmaceutical sectors, but also in agriculture as crop protectants [99-101]. Moreover, their potent and broad-spectrum antimicrobial effects have generated impressive reports in the scientific literature. Thus, several mechanisms of activity have been proposed for EOs and their constituents, including disruption of the phospholipid bilayer of cell membranes, inhibition of efflux pumps, impairment of metabolic pathways, inactivation of genetic material, and anti-quorum sensing effects [102-107]. Compared to antimicrobial drugs, EOs act concurrently towards different microbial targets due to their multicomponent nature, which constitutes an advantage in tackling microbial resistance [108]. In addition to their broad antimicrobial spectrum, EOs have antioxidant, immunomodulatory, anti-inflammatory, and wound healing effects, which highlight them as candidates for the clinical development of novel antimicrobial agents [102,109].

EOs constituents are extremely sensitive to oxygen, light, heat, and humidity. In addition, their low water solubility and bioavailability hamper the clinical use of EOs. Therefore, encapsulation has been widely used to overcome such limitations but also to ensure targeted delivery and to boost the antimicrobial efficacy of EOs $[92,107,110,111]$.

Among the nanoformulated delivery systems, the ability of liposomes to entrap EOs is commonly reported in the literature [112-114].

This section is intended to shed light on the advantages of combining liposomes with the primary chitosan coating (chitosomes) as well as secondary coatings (alginate, hyaluronate, pectin) to overcome the drawbacks of conventional liposomal formulations (aggregations and fusion followed by leakage of their content during storage). Although the application of chitosomes for EOs encapsulation is still in its infancy, it deserves attention.

Considering the antimicrobial propensities of chitosan, such systems are promising tools for the increase of EOs antimicrobial efficacy. Chitosomes could allow targeted delivery of EOs, but also could avail their release, prolonging their bioactivity. They could also reduce the side effects of EOs upon local and systemic administration to humans. 
Therefore, the elucidation of their mechanisms of activity and toxicity in biological systems could pave the way for their use in clinical antimicrobial chemotherapy. Moreover, these formulations might modify the sensory properties of foods and drinks and allow their application as preservatives in the food industry.

Still, EOs chemical composition must be well-characterized, and their encapsulation into chitosomes should focus on these particularities for the development of sound therapeutic approaches.

\title{
6. Conclusions
}

Chitosan has emerged as an important biomaterial for drug delivery. The characteristics of drug-loaded chitosomes and conventional liposomes were compared in this review. The addition of a chitosan layer on the liposome surface resulted in a liposomal size increase and inversion of Zeta potential from negative to positive values. Both size and Zeta potential increased as the chitosan concentration increased until reaching a saturated value. Chitosomes showed an acceptable degree of polydispersity and did not affect the liposome morphology. The chitosan or chitosan derivatives layer improved liposomes stability, even in GI fluid, as well as against severe physical stress during freeze-drying. The results of many studies suggested a sustained drug release from chitosomes, an enhanced mucoadhesivity and skin drug penetration compared to uncoated liposomes. Chitosomes enhanced drug bioavailability as well as their biological effect. The mechanisms controlling drug EE, vesicle stability and drug release in chitosomes depend on many factors, such as physicochemical drug characteristics, medium $\mathrm{pH}$, chitosan MW and chitosan concentration that should be taken into consideration in chitosomal preparation. Chitosan should be added at a saturated concentration to ensure vesicle stability, where coacervates and bridging flocculation may occur, respectively, below this concentration and in the presence of excess chitosan concentration. Moreover, the primary amino groups of chitosan protonated at acidic $\mathrm{pH}$ electrostatically interacted with negatively charged phospholipids on the liposome surface, showing higher stability and lower drug release rate for various drugs used compared to those obtained at high $\mathrm{pH}$ values.

The addition of polyelectrolytes, such as alginate, sodium hyaluronate and pectin, could further enhance the efficacy of chitosomes due to the formation of a denser shell through the ionic interaction of the two polymers, keeping in mind the effect of the medium $\mathrm{pH}$ and polyanionic acid concentration on this interaction. Covering the surface of the liposome with chitosan could be, therefore, considered as a promising strategy to enlarge liposomal applications in areas such as hematology, immunology, pharmaceutics, drug delivery, food packaging and cosmetics.

Author Contributions: The writing-original draft preparation was done by the corresponding author C.S. The co-corresponding author A.T. has also contributed in writing and editing this review especially the part concerning the antimicrobials and essential oils. E.S. helped in editing this review. The conceptualization and the supervision of this review was done by H.G.-G. All authors have read and agreed to the published version of the manuscript.

Funding: This research received no external funding.

Acknowledgments: Authors would like to thank the Agence Universitaire de la Francophonie, Projet de Coopération Scientifique Inter-Universitaire (2018-2020) for supporting the project. This work was supported by a grant from the Romanian Ministry of Education and Research, CNCS-UEFISCDI, project number PN-III-P1-1.1-TE-2019-1894, within PNCDI III.

Conflicts of Interest: The authors declare no conflict of interest.

\author{
Abbreviations \\ AUC area under curve \\ BSA bovine serum albumin \\ Caco-2 human colorectal adenocarcinoma
}




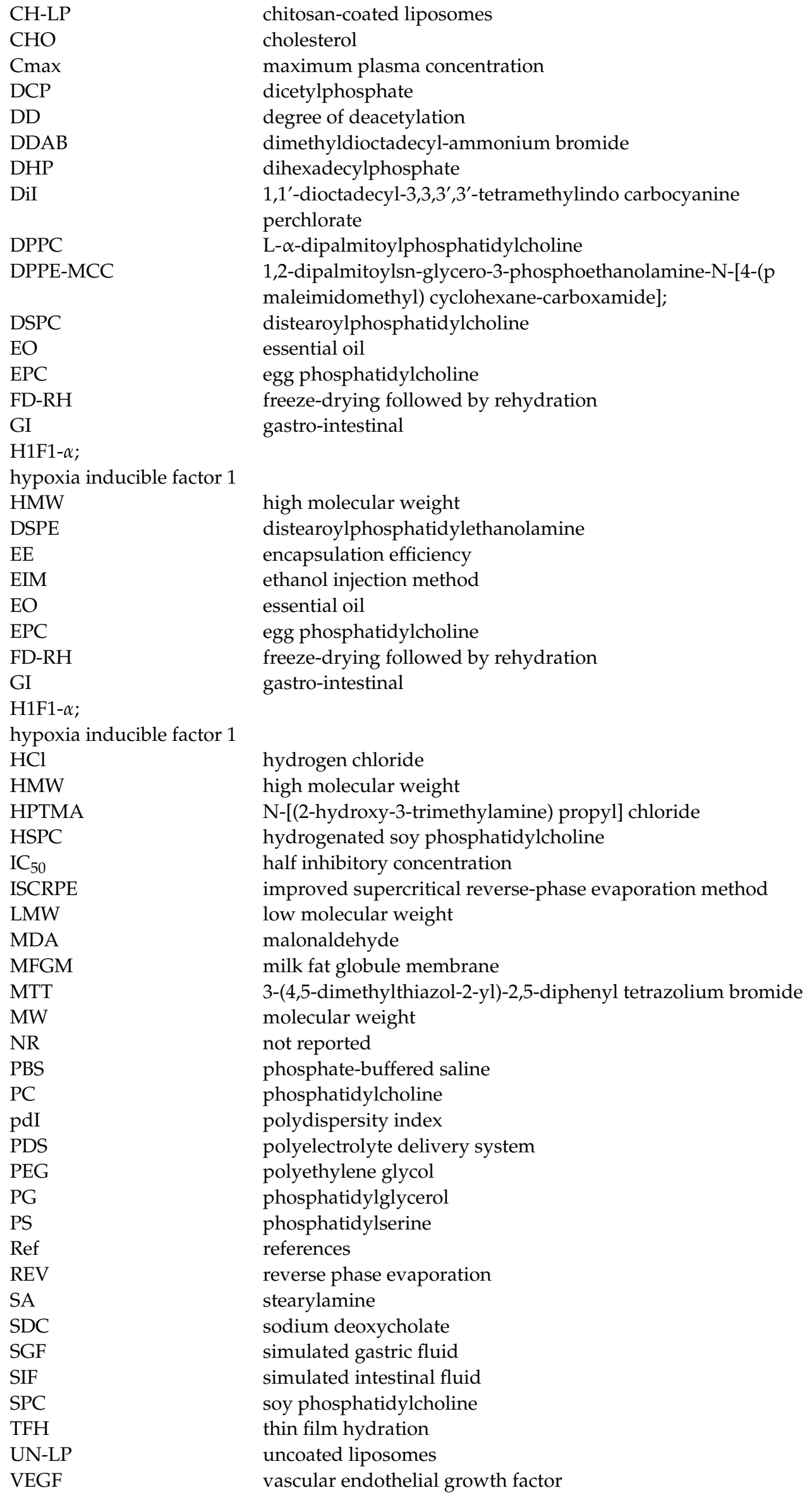




\section{References}

1. Anwekar, H.; Patel, S.; Singhai, A.K. Liposome as drug carriers. Int. J. Pharm. Life Sci. 2011, 2, $945-951$.

2. Barba, A.A.; Bochicchio, S.; Bertoncin, P.; Lamberti, G.; Dalmoro, A. Coating of Nanolipid Structures by a Novel Simil-Microfluidic Technique: Experimental and Theoretical Approaches. Coatings 2019, 9, 491. [CrossRef]

3. Laye, C.; McClements, D.J.; Weiss, J. Formation of Biopolymer-Coated Liposomes by Electrostatic Deposition of Chitosan. J. Food Sci. 2008, 73, N7-N15. [CrossRef]

4. Vural, I.; Sarisozen, C.; Olmez, S.S. Chitosan coated furosemide liposomes for improved bioavailability. J. Biomed. Nanotechnol. 2011, 7, 426-430. [CrossRef]

5. Nguyen, T.X.; Huang, L.; Liu, L.; Abdalla, A.M.E.; Gauthier, M.; Yang, G. Chitosan-coated nano-liposomes for the oral delivery of berberine hydrochloride. J. Mater. Chem. B 2014, 2, 7149-7159. [CrossRef] [PubMed]

6. Sercombe, L.; Veerati, T.; Moheimani, F.; Wu, S.Y.; Sood, A.K.; Hua, S. Advances and Challenges of Liposome Assisted Drug Delivery. Front. Pharmacol. 2015, 6, 286. [CrossRef]

7. Immordino, M.L.; Dosio, F.; Cattel, L. Stealth liposomes: Review of the basic science, rationale, and clinical applications, existing and potential. Int. J. Nanomed. 2006, 1, 297-315.

8. Trucillo, P.; Reverchon, E. Production of PEG-coated liposomes using a continuous supercritical assisted process. J. Supercrit. Fluids 2021, 167, 105048. [CrossRef]

9. Patel, J. Liposomal doxorubicin: Doxil ${ }^{\circledR}$. J. Oncol. Pharm. Pr. 1996, 2, 201-210. [CrossRef]

10. Dash, M.; Chiellini, F.; Ottenbrite, R.M.; Chiellini, E. Chitosan-A versatile semi-synthetic polymer in biomedical applications. Prog. Polym. Sci. 2011, 36, 981-1014. [CrossRef]

11. Wang, Q.Z.; Chen, X.G.; Liu, N.; Wang, S.X.; Liu, C.S.; Meng, X.H.; Liu, C.G. Protonation constants of chitosan with different molecular weight and degree of deacetylation. Carbohydr. Polym. 2006, 65, 194-201. [CrossRef]

12. Li, N.; Zhuang, C.; Wang, M.; Sun, X.; Nie, S.; Pan, W. Liposome coated with low molecular weight chitosan and its potential use in ocular drug delivery. Int. J. Pharm. 2009, 379, 131-138. [CrossRef] [PubMed]

13. Rinaudo, M. Chitin and chitosan: Properties and applications. Progr. Polym. Sci. 2006, 31, 603-632. [CrossRef]

14. Roy, J.; Salaün, F.; Giraud, S.; Ferri, A. Solubility of chitin: Solvents, solution behaviors and their related mechanisms. In Solubility of Polysaccharides; IntechOpen: London, UK, 2017. [CrossRef]

15. Filipović-Grcić, J.; Skalko-Basnet, N.; Jalsenjak, I. Mucoadhesive chitosan-coated liposomes: Characteristics and stability. J. Microencapsul. 2001, 18, 3-12. [CrossRef] [PubMed]

16. Muzzarelli, R.A. Human enzymatic activities related to the therapeutic administration of chitin derivatives. Cell. Mol. Life Sci. 1997, 53, 131-140. [CrossRef] [PubMed]

17. Joraholmen, M.W.; Vanic, Z.; Tho, I.; Skalko-Basnet, N. Chitosan-coated liposomes for topical vaginal therapy: Assuring 2 localized drug effect. Int. J. Pharm. 2014, 472, 94-101. [CrossRef] [PubMed]

18. Ngo, D.H.; Kim, S.K. Antioxidant effects of chitin, chitosan, and their derivatives. Adv. Food. Nutr. Res. 2014, 73, 15-31. [CrossRef] [PubMed]

19. Kong, M.; Chen, X.G.; Xing, K.; Park, H.J. Antimicrobial properties of chitosan and mode of action: A state of the art review. Int. J. Food Microbiol. 2010, 144, 51-63. [CrossRef]

20. Dai, T.; Tanaka, M.; Huang, Y.-Y.; Hamblin, M.R. Chitosan preparations for wounds and burns: Antimicrobial and wound-healing effects. Expert Rev. Anti Infect. Ther. 2011, 9, 857-879. [CrossRef]

21. Raftery, R.; O’Brien, F.J.; Cryan, S.-A. Chitosan for Gene Delivery and Orthopedic Tissue Engineering Applications. Molecules 2013, 18, 5611-5647. [CrossRef]

22. Wang, H.; Zhao, P.; Liang, X.; Gong, X.; Song, T.; Niu, R.; Chang, J. Folate-PEG coated cationic modified chitosan-Cholesterol liposomes for tumor-targeted drug delivery. Biomaterials 2010, 31, 4129-4138. [CrossRef]

23. Yan, L.; Crayton, S.H.; Thawani, J.P.; Amirshaghaghi, A.; Tsourkas, A.; Cheng, Z. A pH-Responsive Drug-Delivery Platform Based on Glycol Chitosan-Coated Liposomes. Small 2015, 11, 4870-4874. [CrossRef]

24. Kowapradit, J.; Opanasopit, P.; Ngawhiranpat, T.; Apirakaramwong, A.; Rojanarata, T.; Ruktanonchai, U.; Sajomsang, W. Methylated N-(4-N,N-Dimethylaminobenzyl) Chitosan, a Novel Chitosan Derivative, Enhances Paracellular Permeability Across Intestinal Epithelial Cells (Caco-2). AAPS PharmSciTech 2008, 9, 1143-1152. [CrossRef] [PubMed]

25. Kowapradit, J.; Apirakaramwong, A.; Ngawhirunpat, T.; Rojanarata, T.; Sajomsang, W.; Opanasopit, P. Methylated N-(4N,N-dimethylaminobenzyl) chitosan coated liposomes for oral protein drug delivery. Eur. J. Pharm. Sci. 2012, 47, 359-366. [CrossRef]

26. Karewicz, A.; Bielska, D.; Loboda, A.; Gzyl-Malcher, B.; Bednar, J.; Jozkowicz, A.; Dulak, J.; Nowakowska, M. Curcumincontaining liposomes stabilized by thin layers of chitosan derivatives. Colloids Surf. B Biointerfaces 2013, 109, 307-316. [CrossRef] [PubMed]

27. Chen, H.; Wu, J.; Sun, M.; Guo, C.; Yu, A.; Cao, F.; Zhao, L.; Tan, Q.; Zhai, G. N-trimethyl chitosan chloride-coated liposomes for the oral delivery of curcumin. J. Liposome Res. 2012, 22, 100-109. [CrossRef] [PubMed]

28. Zhang, J.; Wang, S. Topical use of Coenzyme Q10-loaded liposomes coated with trimethyl chitosan: Tolerance, precorneal retention and anti-cataract effect. Int. J. Pharm. 2009, 372, 66-75. [CrossRef] [PubMed] 
29. Kozhikhova, K.V.; Ivantsova, M.N.; Tokareva, M.I.; Shulepov, I.D.; Tretiyakov, A.V.; Shaidarov, L.V.; Rusinov, V.L.; Mironov, M.A. Preparation of chitosan-coated liposomes as a novel carrier system for the antiviral drug Triazavirin. Pharm. Dev. Technol. 2018, 23, 334-342. [CrossRef]

30. Gradauer, K.; Barthelmes, J.; Vonach, C.; Almer, G.; Mangge, H.; Teubl, B.; Roblegg, E.; Dünnhaupt, S.; Fröhlich, E.; BernkopSchnürch, A.; et al. Liposomes coated with thiolated chitosan enhance oral peptide delivery to rats. J. Control. Release 2013, 172, 872-878. [CrossRef]

31. Bozzuto, G.; Molinari, A. Liposomes as nanomedical devices. Int. J. Nanomed. 2015, 10, 975-999. [CrossRef]

32. Zaru, M.; Manca, M.L.; Fadda, A.M.; Antimisiaris, S.G. Chitosan-coated liposomes for delivery to lungs by nebulization. Colloids Surf. B. Biointerfaces 2009, 71, 88-95. [CrossRef] [PubMed]

33. Lee, C.M.; Kim, D.W.; Lee, K.Y. Effects of chitosan coating for liposomes as an oral carrier. J. Biomed. Sci. 2011, 17, $211-216$.

34. Mengoni, T.; Adrian, M.; Pereira, S.; Santos-Carballal, B.; Kaiser, M.; Goycoolea, F.M. A Chitosan-Based Liposome Formulation Enhances the In Vitro Wound Healing Efficacy of Substance P Neuropeptide. Pharmaceutics 2017, 9, 56. [CrossRef]

35. Zhuang, J.; Ping, Q.; Song, Y.; Qi, J.; Cui, Z. Effects of chitosan coating on physical properties and pharmacokinetic behavior of mitoxantrone liposomes. Int. J. Nanomed. 2010, 5, 407-416. [CrossRef]

36. Van Vuuren, S.F.; Du Toit, L.C.; Parry, A.; Pillay, V.; Choonara, Y.E. Encapsulation of Essential Oils within a Polymeric Liposomal Formulation for Enhancement of Antimicrobial Efficacy. Nat. Prod. Commun. 2010, 5, 1401-1408. [CrossRef] [PubMed]

37. Abdelbary, G. Ocular ciprofloxacin hydrochloride mucoadhesive chitosan-coated liposomes. Pharm. Dev. Technol. 2009, 16, 44-56. [CrossRef]

38. Wu, Z.-H.; Ping, Q.-N.; Wei, Y.; Lai, J.-M. Hypoglycemic efficacy of chitosan-coated insulin liposomes after oral administration in mice. Acta Pharmacol. Sin. 2004, 25, 966-972.

39. Channarong, S.; Chaicumpa, W.; Sinchaipanid, N.; Mitrevej, A. Development and Evaluation of Chitosan-Coated Liposomes for Oral DNA Vaccine: The Improvement of Peyer's Patch Targeting Using a Polyplex-Loaded Liposomes. AAPS PharmSciTec. 2010, 12, 192-200. [CrossRef]

40. Guo, J.; Ping, Q.; Jiang, G.; Huang, L.; Tong, Y. Chitosan-coated liposomes: Characterization and interaction with leuprolide. Int. J. Pharm. 2003, 260, 167-173. [CrossRef]

41. Liu, N.; Park, H.-J. Factors effect on the loading efficiency of Vitamin C loaded chitosan-coated nanoliposomes. Colloids Surf. B Biointerfaces 2010, 76, 16-19. [CrossRef]

42. Park, S.N.; Jo, N.R.; Jeon, S.H. Chitosan-coated liposomes for enhanced skin permeation of resveratrol. J. Ind. Eng. Chem. 2014, 20, 1481-1485. [CrossRef]

43. Shin, G.H.; Chung, S.K.; Kim, J.T.; Joung, H.J.; Park, H.J. Preparation of Chitosan-Coated Nanoliposomes for Improving the Mucoadhesive Property of Curcumin Using the Ethanol Injection Method. J. Agric. Food Chem. 2013, 61, 11119-11126. [CrossRef] [PubMed]

44. Tan, C.; Feng, B.; Zhang, X.; Xia, W.; Xia, S. Biopolymer-coated liposomes by electrostatic adsorption of chitosan (chitosomes) as novel delivery systems for carotenoids. Food Hydrocoll. 2016, 52, 774-784. [CrossRef]

45. Tan, H.W.; Misran, M. Characterization of fatty acid liposome coated with low-molecular-weight chitosan. J. Liposome Res. 2012, 22, 329-335. [CrossRef]

46. Venturini, M.; Mazzitelli, S.; Mičetić, I.; Benini, C.; Fabri, J.; Mucelli, S.P.; Benetti, F.; Nastruzzi, C. Analysis of Operating Conditions Influencing the Morphology and In vitro Behaviour of Chitosan Coated Liposomes. J. Nanomed. Nanotechnol. 2014, 5, 1-8. [CrossRef]

47. Wang, Y.; Tu, S.; Li, R.; Yang, X.; Liu, L.; Zhang, Q. Cholesterol succinyl chitosan anchored liposomes: Preparation, characterization, physical stability, and drug release behavior. Nanomed. Nanotechnol. Biol. Med. 2010, 6, 471-477. [CrossRef]

48. Li, L.; Zhang, Y.; Han, S.; Qu, Z.; Zhao, J.; Chen, Y.; Chen, Z.; Duan, J.; Pan, Y.; Tang, X. Penetration enhancement of lidocaine hydrochlorid by a novel chitosan coated elastic liposome for transdermal drug delivery. J. Biomed. Nanotechnol. 2011, 7, 704-713. [CrossRef] [PubMed]

49. Li, Z.; Paulson, A.T.; Gill, T.A. Encapsulation of bioactive salmon protein hydrolysates with chitosan-coated liposomes. J. Funct. Foods 2015, 19, 733-743. [CrossRef]

50. Diebold, Y.; Jarrín, M.; Sáez, V.; Carvalho, E.L.S.; Orea, M.; Calonge, M.; Seijo, B.; Alonso, M.J. Ocular drug delivery by liposome-chitosan nanoparticle complexes (LCS-NP). Biomaterials 2007, 28, 1553-1564. [CrossRef] [PubMed]

51. Mady, M.M.; Darwish, M.M.; Khalil, S.; Khalil, W.M. Biophysical studies on chitosan-coated liposomes. Eur. Biophys. J. 2009, 38, 1127-1133. [CrossRef] [PubMed]

52. Mady, M.M.; Darwish, M.M. Effect of chitosan coating on the characteristics of DPPC liposomes. J. Adv. Res. 2010, 1, 187-191. [CrossRef]

53. Wang, W.-X.; Gao, J.-Q.; Liang, W.-Q. Chitosan-coated liposomes for intracellular oligonucleotides delivery: Characteristics and cell uptake behavior. Drug Deliv. 2010, 18, 208-214. [CrossRef] [PubMed]

54. Thongborisute, J.; Tsuruta, A.; Kawabata, Y.; Takeuchi, H. The effect of particle structure of chitosan-coated liposomes and type of chitosan on oral delivery of calcitonin. J. Drug Target. 2006, 14, 147-154. [CrossRef] [PubMed]

55. Alshraim, M.O.; Sangi, S.; Harisa, G.I.; Alomrani, A.H.; Yusuf, O.; Badran, M.M. Chitosan-Coated Flexible Liposomes Magnify the Anticancer Activity and Bioavailability of Docetaxel: Impact on Composition. Molecules 2019, 24, 250. [CrossRef] [PubMed] 
56. Yang, Z.; Liu, J.; Gao, J.; Chen, S.; Huang, G. Chitosan coated vancomycin hydrochloride liposomes: Characterizations and evaluation. Int. J. Pharm. 2015, 495, 508-515. [CrossRef] [PubMed]

57. Behera, T.; Swain, P.; Sahoo, S. Antigen in chitosan coated liposomes enhances immune responses through parenteral immunization. Int. Immunopharmacol. 2011, 11, 907-914. [CrossRef]

58. Ben, M.S.; Marina, K.; Mukund, G.S. Eudragit S-100 Encapsulated Chitosan Coated Liposomes Containing Prednisolone for Colon Targeting: In vitro, Ex vivo and In vivo Evaluation. J. Young Pharm. 2019, 11, 7-11. [CrossRef]

59. Chen, D.; Xia, D.; Li, X.; Zhu, Q.; Yu, H.; Zhu, C.; Gan, Y. Comparative study of Pluronic ${ }^{\circledR}$ F127-modified liposomes and chitosan-modified liposomes for mucus penetration and oral absorption of cyclosporine A in rats. Int. J. Pharm. 2013, 449, 1-9. [CrossRef]

60. Alshamsan, A.; Aleanizy, F.S.; Badran, M.; Alqahtani, F.Y.; Alfassam, H.; Almalik, A.; Alosaimy, S. Exploring anti-MRSA activity of chitosan-coated liposomal dicloxacillin. J. Microbiol. Methods 2019, 156, 23-28. [CrossRef]

61. Chen, H.; Pan, H.; Li, P.; Wang, H.; Wang, X.; Pan, W.; Yuan, Y. The potential use of novel chitosan-coated deformable liposomes in an ocular drug delivery system. Colloids Surf. B Biointerfaces 2016, 143, 455-462. [CrossRef]

62. Gibis, M.; Ruedt, C.; Weiss, J. In vitro release of grape-seed polyphenols encapsulated from uncoated and chitosan-coated liposomes. Food Res. Int. 2016, 88, 105-113. [CrossRef]

63. Karn, P.R.; Vanić, Z.; Pepić, I.; Škalko-Basnet, N. Mucoadhesive liposomal delivery systems: The choice of coating material. Drug Dev. Ind. Pharm. 2010, 37, 482-488. [CrossRef] [PubMed]

64. Liu, W.; Liu, W.; Ye, A.; Peng, S.; Wei, F.; Liu, C.; Han, J. Environmental stress stability of microencapsules based on liposomes decorated with chitosan and sodium alginate. Food Chem. 2016, 196, 396-404. [CrossRef] [PubMed]

65. Gültekin-Özgüven, M.; Karadağ, A.; Duman, S.; Özkal, B.; Özçelik, B. Fortification of dark chocolate with spray dried black mulberry (Morus nigra) waste extract encapsulated in chitosan-coated liposomes and bioaccessability studies. Food Chem. 2016, 201, 205-212. [CrossRef] [PubMed]

66. Liu, Y.; Liu, D.; Zhu, L.; Gan, Q.; Le, X. Temperature-dependent structure stability and in vitro release of chitosan-coated curcumin liposome. Food Res. Int. 2015, 74, 97-105. [CrossRef]

67. Cuomo, F.; Cofelice, M.; Venditti, F.; Ceglie, A.; Miguel, M.; Lindman, B.; Lopez, F. In-vitro digestion of curcumin loaded chitosan-coated liposomes. Colloids Surf. B Biointerfaces 2018, 168, 29-34. [CrossRef]

68. Gibis, M.; Rahn, N.; Weiss, J. Physical and Oxidative Stability of Uncoated and Chitosan-Coated Liposomes Containing Grape Seed Extract. Pharmaceutics 2013, 5, 421-433. [CrossRef] [PubMed]

69. Panya, A.; Laguerre, M.; LeComte, J.; Villeneuve, P.; Weiss, J.; McClements, D.J.; Decker, E.A. Effects of Chitosan and Rosmarinate Esters on the Physical and Oxidative Stability of Liposomes. J. Agric. Food Chem. 2010, 58, 5679-5684. [CrossRef]

70. Liu, N.; Park, H.-J. Chitosan-coated nanoliposome as vitamin E carrier. J. Microencapsul. 2009, 26, 235-242. [CrossRef]

71. Cui, H.Y.; Wu, J.; Li, C.Z.; Lin, L. Anti-listeria effects of chitosan-coated nisin-silica liposome on Cheddar cheese. J. Dairy Sci. 2016, 99, 8598-8606. [CrossRef] [PubMed]

72. Quagliariello, V.; Masarone, M.; Armenia, E.; Giudice, A.; Barbarisi, M.; Caraglia, M.; Barbarisi, A.; Persico, M. Chitosan-coated liposomes loaded with butyric acid demonstrate anticancer and anti-inflammatory activity in human hepatoma HepG2 cells. Oncol. Rep. 2019, 41, 1476-1486. [CrossRef] [PubMed]

73. Qiang, F.; Shin, H.-J.; Lee, B.-J.; Han, H.-K. Enhanced systemic exposure of fexofenadine via the intranasal administration of chitosan-coated liposome. Int. J. Pharm. 2012, 430, 161-166. [CrossRef] [PubMed]

74. Chen, M.-X.; Li, B.-K.; Yin, D.-K.; Liang, J.; Li, S.-S.; Peng, D.-Y. Layer-by-layer assembly of chitosan stabilized multilayered liposomes for paclitaxel delivery. Carbohydr. Polym. 2014, 111, 298-304. [CrossRef] [PubMed]

75. Salva, E.; Turan, S.O.; Eren, F.; Akbuğa, J. The enhancement of gene silencing efficiency with chitosan-coated liposome formulations of siRNAs targeting HIF-1 $\alpha$ and VEGF. Int. J. Pharm. 2015, 478, 147-154. [CrossRef]

76. Otake, K.; Shimomura, T.; Goto, T.; Imura, T.; Furuya, T.; Yoda, S.; Takebayashi, Y.; Sakai, H.; Abe, M. One-Step Preparation of Chitosan-Coated Cationic Liposomes by an Improved Supercritical Reverse-Phase Evaporation Method. Langmuir 2006, 22, 4054-4059. [CrossRef]

77. Mozuraityte, R.; Rustad, T.; Storrø, I. The Role of Iron in Peroxidation of Polyunsaturated Fatty Acids in Liposomes. J. Agric. Food Chem. 2008, 56, 537-543. [CrossRef]

78. Lin, L.; Gu, Y.; Sun, Y.; Cui, H. Characterization of chrysanthemum essential oil triple-layer liposomes and its application against Campylobacter jejuni on chicken. LWT 2019, 107, 16-24. [CrossRef]

79. Li, N.; Zhuang, C.-Y.; Wang, M.; Sui, C.-G.; Pan, W.-S. Low molecular weight chitosan-coated liposomes for ocular drug delivery: In vitro and in vivo studies. Drug Deliv. 2012, 19, 28-35. [CrossRef]

80. Jeon, S.; Yoo, C.Y.; Park, S.N. Improved stability and skin permeability of sodium hyaluronate-chitosan multilayered liposomes by Layer-by-Layer electrostatic deposition for quercetin delivery. Colloids Surf. B Biointerfaces 2015, 129, 7-14. [CrossRef]

81. Takeuchi, H.; Matsui, Y.; Yamamoto, H.; Kawashima, Y. Mucoadhesive properties of carbopol or chitosan-coated liposomes and their effectiveness in the oral administration of calcitonin to rats. J. Control. Release 2003, 86, 235-242. [CrossRef]

82. Takeuchi, H.; Matsui, Y.; Sugihara, H.; Yamamoto, H.; Kawashima, Y. Effectiveness of submicron-sized, chitosan-coated liposomes in oral administration of peptide drugs. Int. J. Pharm. 2005, 303, 160-170. [CrossRef] [PubMed]

83. Jøraholmen, M.W.; Bhargava, A.; Julin, K.; Johannessen, M.; Škalko-Basnet, N. The Antimicrobial Properties of Chitosan Can Be Tailored by Formulation. Mar. Drugs 2020, 18, 96. [CrossRef] [PubMed] 
84. Andersen, T.; Mishchenko, E.; Flaten, G.E.; Sollid, J.U.E.; Mattsson, S.; Tho, I.; Škalko-Basnet, N. Chitosan-Based Nanomedicine to Fight Genital Candida Infections: Chitosomes. Mar. Drugs 2017, 15, 64. [CrossRef] [PubMed]

85. Niaz, T.; Shabbir, S.; Noor, T.; Rahman, A.; Bokhari, H.; Imran, M. Potential of polymer stabilized nano-liposomes to enhance antimicrobial activity of nisin Z against foodborne pathogens. LWT 2018, 96, 98-110. [CrossRef]

86. Serra, L.; Doménech, J.; Peppas, N. Engineering design and molecular dynamics of mucoadhesive drug delivery systems as targeting agents. Eur. J. Pharm. Biopharm. 2009, 71, 519-528. [CrossRef]

87. Dünnhaupt, S.; Barthelmes, J.; Thurner, C.C.; Waldner, C.; Sakloetsakun, D.; Bernkop-Schnürch, A. S-protected thiolated chitosan: Synthesis and in vitro characterization. Carbohydr. Polym. 2012, 90, 765-772. [CrossRef]

88. Sugihara, H.; Yamamoto, H.; Kawashima, Y.; Takeuchi, H. Effects of food intake on the mucoadhesive and gastroretentive properties of submicron-sized chitosan-coated liposomes. Chem. Pharm. Bull. 2012, 60, 1320-1323. [CrossRef]

89. Haidar, Z.S.; Hamdy, R.C.; Tabrizian, M. Protein release kinetics for core-shell hybrid nanoparticles based on the layer-by-layer assembly of alginate and chitosan on liposomes. Biomaterials 2008, 29, 1207-1215. [CrossRef]

90. Liu, W.; Liu, J.; Liu, W.; Li, T.; Liu, C. Improved Physical and in Vitro Digestion Stability of a Polyelectrolyte Delivery System Based on Layer-by-Layer Self-Assembly Alginate-Chitosan-Coated Nanoliposomes. J. Agric. Food Chem. 2013, 61, 4133-4144. [CrossRef]

91. Gibis, M.; Zeeb, B.; Weiss, J. Formation, characterization, and stability of encapsulated hibiscus extract in multilayered liposomes. Food Hydrocoll. 2014, 38, 28-39. [CrossRef]

92. Dajic Stevanovic, Z.; Sieniawska, E.; Glowniak, K.; Obradovic, N.; Pajic-Lijakovic, I. Natural Macromolecules as Carriers for Essential Oils: From Extraction to Biomedical Application. Front. Bioeng. Biotechnol. 2020, 8, 563. [CrossRef] [PubMed]

93. Bakkali, F.; Averbeck, S.; Averbeck, D.; Idaomar, M. Biological effects of essential oils-A review. Food Chem. Toxicol. 2008, 46, 446-475. [CrossRef] [PubMed]

94. Swamy, M.K.; Akhtar, M.S.; Sinniah, U.R. Antimicrobial Properties of Plant Essential Oils against Human Pathogens and Their Mode of Action: An Updated Review. Evid. Based Complement. Altern. Med. 2016, 2016, 1-21. [CrossRef] [PubMed]

95. Dilworth, L.L.; Riley, C.K.; Stennett, D.K. Plant Constituents: Carbohydrates, Oils, Resins, Balsams, and Plant Hormones. In Pharmacognosy. Fundamentals, Applications and Strategy; Badal, S., Delgoda, R., Eds.; Academic Press: London, UK, 2017; pp. 61-80.

96. Schmidt, E. Production of Essential Oils. In Handbook of Essential Oils: Science, Technology, and Applications; Can Baser, K.H., Buchbauer, G., Eds.; CRC Press: Boca Raton, FL, USA, 2010; pp. 83-120.

97. Bucar, F.; Wube, A.; Schmid, M. Natural product isolation: How to get from biological material to pure compounds. Nat. Prod. Rep. 2013, 30, 525-545. [CrossRef]

98. Simona, J.; Dani, D.; Petr, S.; Marcela, N.; Jakub, T.; Bohuslava, T. Edible Films from Carrageenan/Orange Essential Oil/TrehaloseStructure, Optical Properties, and Antimicrobial Activity. Polymers 2021, 13, 332. [CrossRef] [PubMed]

99. Hyldgaard, M.; Mygind, T.; Meyer, R.L. Essential Oils in Food Preservation: Mode of Action, Synergies, and Interactions with Food Matrix Components. Front. Microbiol. 2012, 3, 12. [CrossRef] [PubMed]

100. Raut, J.S.; Karuppayil, S.M. A status review on the medicinal properties of essential oils. Ind. Crop. Prod. 2014, 62, 250-264. [CrossRef]

101. Sarkic, A.; Stappen, I. Essential Oils and Their Single Compounds in Cosmetics-A Critical Review. Cosmetics $2018,5,11$. [CrossRef]

102. Hammer, K.A.; Carson, C.F. Antibacterial and antifungal activities of essential oils. In Lipids and Essential Oils as Antimicrobial Agents; Thormar, H., Ed.; John Wiley \& Sons, Ltd.: Chichester, UK, 2011; pp. 255-295.

103. Bassolé, I.H.N.; Juliani, H.R. Essential Oils in Combination and Their Antimicrobial Properties. Molecules 2012, 17, 3989-4006. [CrossRef] [PubMed]

104. Nazzaro, F.; Fratianni, F.; De Martino, L.; Coppola, R.; De Feo, V. Effect of Essential Oils on Pathogenic Bacteria. Pharmaceuticals 2013, 6, 1451-1474. [CrossRef] [PubMed]

105. Langeveld, W.T.; Veldhuizen, E.J.A.; Burt, S.A. Synergy between essential oil components and antibiotics: A review. Crit. Rev. Microbiol. 2014, 40, 76-94. [CrossRef] [PubMed]

106. Tariq, S.; Wani, S.; Rasool, W.; Shafi, K.; Bhat, M.A.; Prabhakar, A.; Shalla, A.H.; Rather, M.A. A comprehensive review of the antibacterial, antifungal and antiviral potential of essential oils and their chemical constituents against drug-resistant microbial pathogens. Microb. Pathog. 2019, 134, 103580. [CrossRef]

107. Trifan, A.; Luca, S.V.; Greige-Gerges, H.; Miron, A.; Gille, E.; Aprotosoaie, A.C. Recent advances in tackling microbial multidrug resistance with essential oils: Combinatorial and nano-based strategies. Crit. Rev. Microbiol. 2020, 46, 1-20. [CrossRef] [PubMed]

108. Kon, K.V.; Rai, M.K. Plant essential oils and their constituents in coping with multidrug-resistant bacteria. Expert Rev. Anti Infect. Ther. 2012, 10, 775-790. [CrossRef] [PubMed]

109. Subramani, R.; Narayanasamy, M.; Feussner, K.-D. Plant-derived antimicrobials to fight against multi-drug-resistant human pathogens. 3 Biotech 2017, 7, 172. [CrossRef]

110. Kfoury, M.; Auezova, L.; Greige-Gerges, H.; Fourmentin, S. Promising applications of cyclodextrins in food: Improvement of essential oils retention, controlled release and antiradical activity. Carbohydr. Polym. 2015, 131, 264-272. [CrossRef]

111. Doost, A.S.; Nasrabadi, M.N.; Kassozi, V.; Nakisozi, H.; Van Der Meeren, P. Recent advances in food colloidal delivery systems for essential oils and their main components. Trends Food Sci. Technol. 2020, 99, 474-486. [CrossRef] 
112. Sherry, M.; Charcosset, C.; Fessi, H.; Greige-Gerges, H. Essential oils encapsulated in liposomes: A review. J. Liposome Res. 2013, 23, 268-275. [CrossRef] [PubMed]

113. Majeed, H.; Bian, Y.-Y.; Ali, B.; Jamil, A.; Majeed, U.; Khan, Q.F.; Iqbal, K.J.; Shoemaker, C.F.; Fang, Z. Essential oil encapsulations: Uses, procedures, and trends. RSC Adv. 2015, 5, 58449-58463. [CrossRef]

114. Ahmad, R.; Srivastava, S.; Ghosh, S.; Khare, S.K. Phytochemical delivery through nanocarriers: A review. Colloids Surf. B Biointerfaces 2021, 197, 111389. [CrossRef] 